Prepared for the U.S. Army Corps of Engineers, Portland District,

Under a Government Order with the U.S. Department of Energy

Contract DE-AC05-76RL01830

\title{
Compliance Monitoring of Yearling Chinook Salmon and Juvenile Steelhead Survival and Passage at John Day Dam, Spring 2011
}

\section{COMPLIANCE REPORT}
JR Skalski
CM Woodley
RL Townsend JS Hughes
AG Seaburg
TJ Carlson
MA Weiland

February 2012

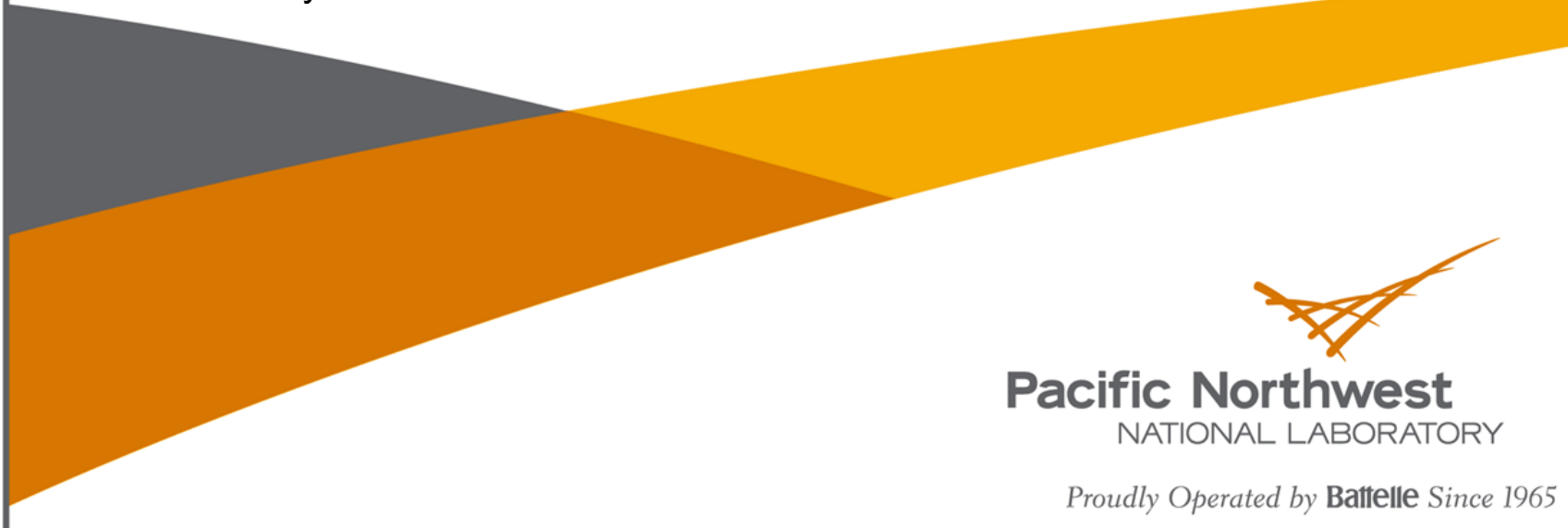




\title{
DISCLAIMER
}

This report was prepared as an account of work sponsored by an agency of the United States Government. Neither the United States Government nor any agency thereof, nor Battelle Memorial Institute, nor any of their employees, makes any warranty, express or implied, or assumes any legal liability or responsibility for the accuracy, completeness, or usefulness of any information, apparatus, product, or process disclosed, or represents that its use would not infringe privately owned rights. Reference herein to any specific commercial product, process, or service by trade name, trademark, manufacturer, or otherwise does not necessarily constitute or imply its endorsement, recommendation, or favoring by the United States Government or any agency thereof, or Battelle Memorial Institute. The views and opinions of authors expressed herein do not necessarily state or reflect those of the United States Government or any agency thereof.

\author{
PACIFIC NORTHWEST NATIONAL LABORATORY \\ operated by \\ BATTELLE \\ for the \\ UNITED STATES DEPARTMENT OF ENERGY \\ under Contract DE-AC05-76RL01830
}

Printed in the United States of America

Available to DOE and DOE contractors from the

Office of Scientific and Technical Information,

P.O. Box 62, Oak Ridge, TN 37831-0062;

ph: (865) 576-8401

fax: $(865) 576-5728$

email: reports@adonis.osti.gov

\author{
Available to the public from the National Technical Information Service \\ 5301 Shawnee Rd., Alexandria, VA 22312 \\ ph: (800) 553-NTIS (6847) \\ email: orders@ntis.gov <http://www.ntis.gov/about/form.aspx> \\ Online ordering: http://www.ntis.gov
}

This document was printed on recycled paper. 


\title{
Compliance Monitoring of Yearling Chinook Salmon and Juvenile Steelhead Survival and Passage at John Day Dam, Spring 2011
}

Compliance Report

\author{
JR Skalski ${ }^{1} \quad$ CM Woodley \\ RL Townsend ${ }^{1} \quad$ JS Hughes \\ AG Seaburg ${ }^{1}$ \\ TJ Carlson \\ MA Weiland
}

February 2012

Prepared for

U.S. Army Corps of Engineers, Portland District

Under a Government Order with the U.S. Department of Energy

Contract DE-AC05-76RL01830

\footnotetext{
${ }^{1}$ University of Washington, Seattle, Washington
} 


\section{Preface}

This study was conducted by the Pacific Northwest National Laboratory (PNNL) and the University of Washington (UW) for the U.S. Army Corps of Engineers, Portland District (USACE). The PNNL and UW project managers are Drs. Thomas J. Carlson and John R. Skalski, respectively. The USACE technical lead is Mr. Brad Eppard. The study was designed to estimate dam passage survival at John Day Dam as stipulated by the 2008 Federal Columbia River Power System (FCRPS) Biological Opinion (BiOp) and provide additional performance measures at that site as stipulated in the Columbia Basin Fish Accords.

This summary report focuses on the spring run stocks, yearling Chinook salmon and steelhead. A comprehensive technical report of the 2011 tagging studies at John Day Dam will be delivered in 2012. 


\section{Executive Summary}

The purpose of this compliance study was to estimate dam passage survival of yearling Chinook salmon and steelhead smolts at John Day Dam during spring 2011. Under the 2008 Federal Columbia River Power System (FCRPS) Biological Opinion (BiOp), dam passage survival should be greater than or equal to 0.96 and estimated with a standard error (SE) less than or equal to 0.015 . The study also estimated smolt passage survival from the forebay $2 \mathrm{~km}$ upstream of the dam to the tailrace $3 \mathrm{~km}$ below the dam, ${ }^{1}$ as well as the forebay residence time, tailrace egress, and spill passage efficiency (SPE), as required in the Columbia Basin Fish Accords (Fish Accords).

A virtual/paired-release design was used to estimate dam passage survival at John Day Dam. The approach included releases of acoustic-tagged smolts above John Day Dam that contributed to the formation of a virtual release at the face of John Day Dam. A survival estimate from this release was adjusted by a paired release below John Day Dam. A total of 2441 yearling Chinook salmon and 2469 steelhead smolts were used in the virtual releases. Sample sizes for the below-dam paired releases were 1193 and 799 for yearling Chinook salmon smolts and 1196 and 797 for steelhead smolts. The Juvenile Salmon Acoustic Telemetry System (JSATS) tag model number ATS-156dB, weighing $0.438 \mathrm{~g}$ in air, was used in this investigation.

The intent of the spring study was to estimate dam passage survival during both $30 \%$ and $40 \%$ spill conditions. The two spill conditions were to be systematically performed in alternating 2-day test intervals over the course of the spring outmigration. High flow conditions and mandatory spill during flood conditions interrupted the spill trials halfway through the study. Dam passage survival was therefore estimated separately before (i.e., early) and during (i.e., late) high flow conditions.

The study results are summarized in the following tables.

Table ES.1. Estimates of dam passage survival at John Day Dam in 2011. ${ }^{\text {(a) }}$

\begin{tabular}{lcc}
\hline \multicolumn{1}{c}{ Spill Operations } & Yearling Chinook Salmon & Steelhead \\
\hline $30 \%$ early season (27 April - 16 May) & $0.9666(0.0103)$ & $0.9836(0.0090)$ \\
$40 \%$ early season (27 April - 16 May) & $0.9784(0.0107)$ & $0.9897(0.0096)$ \\
Late season (16 May - 29 May) & $0.9702(0.0058)$ & $0.9899(0.0094)$ \\
Season-wide & $0.9676(0.0071)$ & $0.9867(0.0061)$ \\
\hline
\end{tabular}

(a) Dam passage survival is defined as survival from the upstream face of the dam to a standardized reference point in the tailrace.

\footnotetext{
${ }^{1}$ The forebay-to-tailrace survival estimate satisfies the "BRZ-to-BRZ" survival estimate called for in the Fish Accords.
} 
Table ES.2. Fish Accords performance measures at John Day Dam in 2011.

\begin{tabular}{lcc}
\hline \multicolumn{1}{c}{ Performance Measures } & Yearling Chinook Salmon & Steelhead \\
\hline Forebay-to-tailrace survival (season-wide) & $0.9646(0.0072)$ & $0.9801(0.0062)$ \\
Forebay residence time (median; mean) & $1.42 ; 2.93 \mathrm{~h}(0.13)$ & $2.91 ; 6.88 \mathrm{~h}(0.20)$ \\
Tailrace egress rate (median; mean) & $0.57 ; 3.98 \mathrm{~h}(0.49)$ & $0.58 ; 9.09 \mathrm{~h}(0.70)$ \\
Spill passage efficiency ${ }^{(a)}$ & $0.6368(0.0093)$ & $0.6278(0.0097)$ \\
Fish passage efficiency & $0.8848(0.0065)$ & $0.9600(0.0039)$ \\
\hline
\end{tabular}

(a) By definition in the Fish Accords, SPE includes the spillway and the ice and trash sluiceway at John Day Dam. However, the point estimate provided includes only spillway passage, not sluiceway passage. 
Table ES.3. Survival study summary.

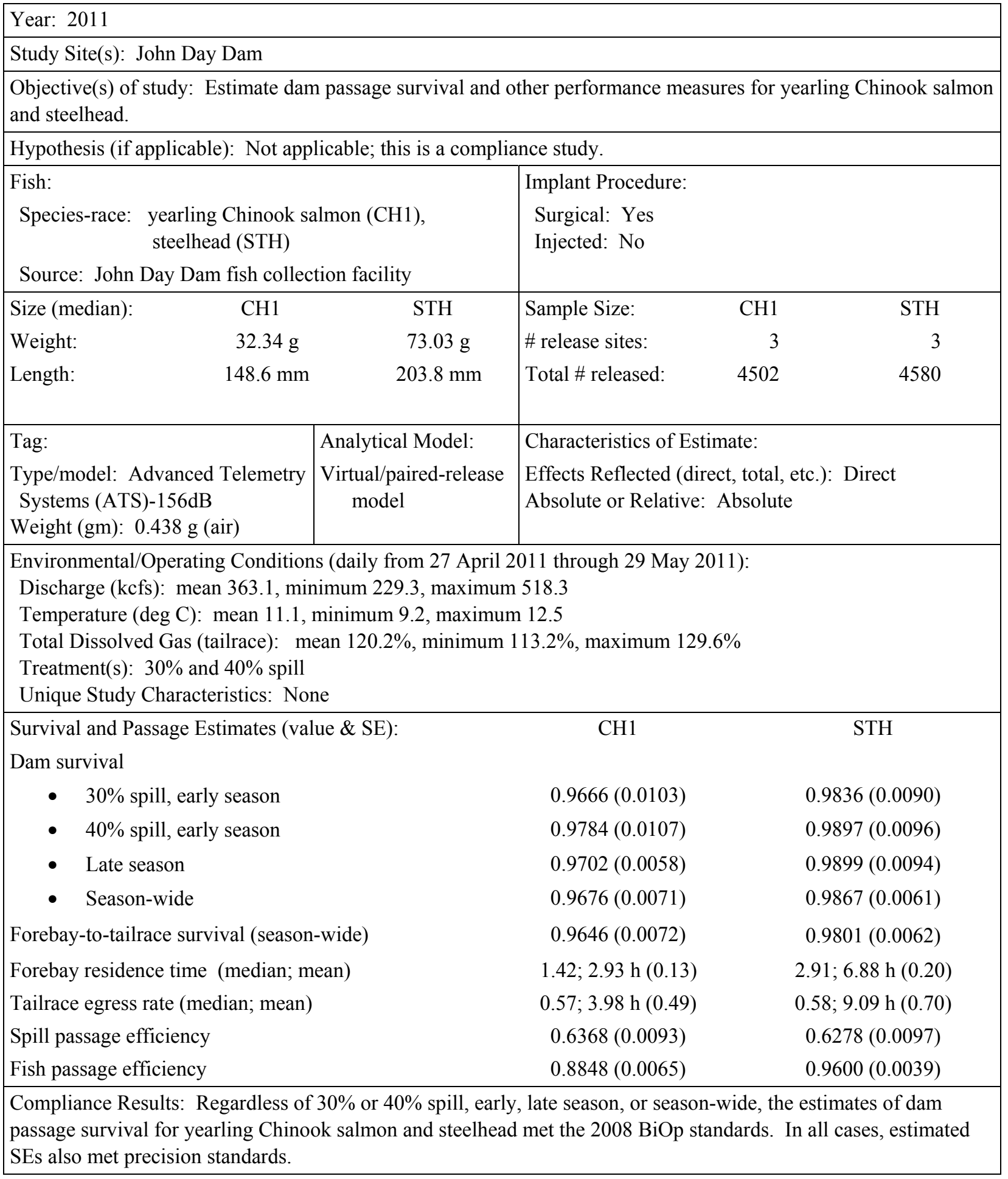




\section{Acknowledgments}

This study was the result of hard work by dedicated scientists from the Pacific Northwest National Laboratory (PNNL), Pacific States Marine Fisheries Commission (PSMFC), the U.S. Army Corps of Engineers, Portland District (USACE), and the University of Washington (UW). Their teamwork and attention to detail, schedule, and budget were essential for the study to succeed in providing high-quality, timely results to decision-makers.

- PNNL: C Arimescu, T Able, G Batten, C Brandt, A Bryson, K Carter, E Choi, D Deng, K Deters, G Dirkes, J Duncan, D Faber, E Fischer, A Flory, T Fu, D Geist, K Hall, M Halvorsen, K Ham, K Hand, M Hennen, JL Hughes, JS Hughes, G Johnson, F Kahn, R Karls, J Kim, B LaMarche, K Larson, K Lavender, J Martinez, B Miller, A Miracle, A Phillips, G Ploskey, G Roesijadi, I Royer, D Saunders, J Smith, G Squeochs, S Southard, N Tavin, A Thronas, S Titzler, N Trimble, D Trott, K Wagner, M Weiland, C Woodley, J Varvinec, S Zimmerman

- PSMFC: G Kolvachuk and D Ballenger along with the helpful staff at John Day and Bonneville Dam Juvenile Smolt Facilities. In addition, B Babcock, R Blanchard, S Carpenter, A Collins, A Cushing, L Cushing, T Elder, D Etherington, M Gay, G George, A Halston, C Holzer, M Jenkins, K Knox, D Lock, R Martinson, D Marvin, T Monter, T Mitchell, M Neumann, T Royal, K Schaedel, $\mathrm{N}$ Tancreto, R Wall

- USACE: B Eppard, M Langeslay, and electricians, mechanics, riggers, operators, and biologists at John Day (M Zyndol, T Hurd), The Dalles (B Cordie) and Bonneville dams (J Rerecich, B Hausmann, A Traylor)

- UW: J Skalski, J Lady, A Seaburg, R Townsend, and P Westhagen 


\section{Acronyms and Abbreviations}

\begin{tabular}{|c|c|}
\hline${ }^{\circ} \mathrm{C}$ & degree(s) Celsius \\
\hline $3 \mathrm{D}$ & three dimensional \\
\hline ATS & Advanced Telemetry Systems \\
\hline $\mathrm{BiOp}$ & biological opinion \\
\hline $\mathrm{BRZ}$ & boat-restricted zone \\
\hline $\mathrm{CH} 1$ & yearling Chinook salmon \\
\hline FCRPS & Federal Columbia River Power System \\
\hline FPE & fish passage efficiency \\
\hline $\mathrm{g}$ & $\operatorname{gram}(\mathrm{s})$ \\
\hline $\mathrm{h}$ & hours(s) \\
\hline JSATS & Juvenile Salmon Acoustic Telemetry System \\
\hline $\mathrm{kcfs}$ & thousand cubic feet per second \\
\hline $\mathrm{km}$ & kilometer(s) \\
\hline $\mathrm{L}$ & liter(s) \\
\hline $\mathrm{m}$ & meter(s) \\
\hline $\mathrm{mg}$ & milligram(s) \\
\hline $\mathrm{mm}$ & millimeter(s) \\
\hline PIT & passive integrated transponder \\
\hline PNNL & Pacific Northwest National Laboratory \\
\hline PRI & pulse repetition interval \\
\hline PSMFC & Pacific States Marine Fisheries Commission \\
\hline rkm & river kilometer(s) \\
\hline RME & research, monitoring, and evaluation \\
\hline ROR & run-of-river \\
\hline RPA & reasonable and prudent alternative \\
\hline s & second(s) \\
\hline $\mathrm{SE}$ & standard error \\
\hline SPE & spill passage efficiency \\
\hline STH & steelhead \\
\hline USACE & U.S. Army Corps of Engineers \\
\hline UW & University of Washington \\
\hline
\end{tabular}




\section{Contents}

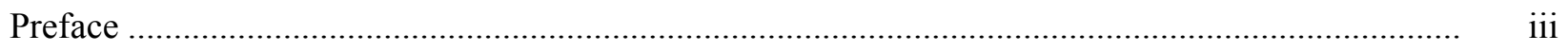

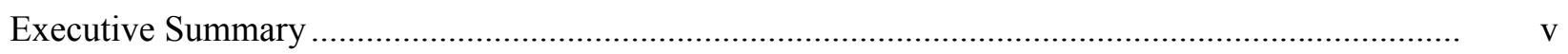

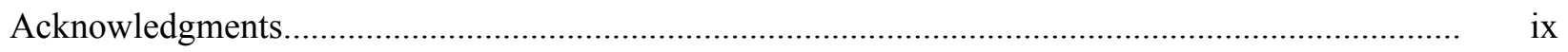

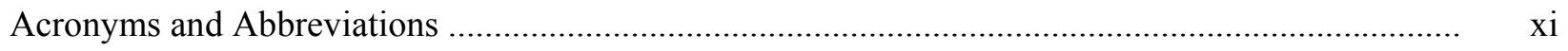

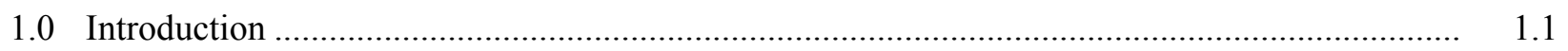

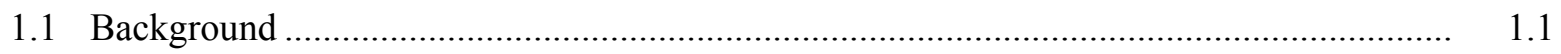

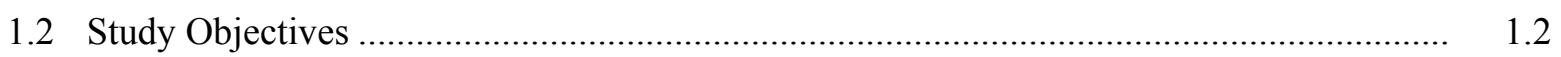

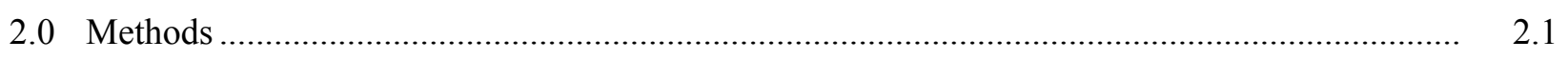

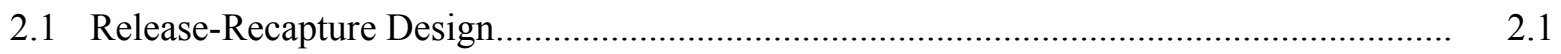

2.2 Handling, Tagging, and Release Procedures ................................................................ 2.3

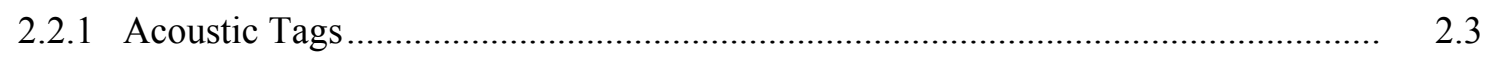

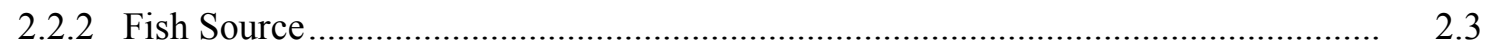

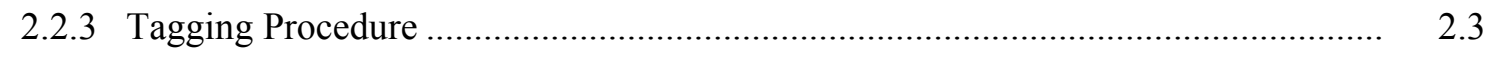

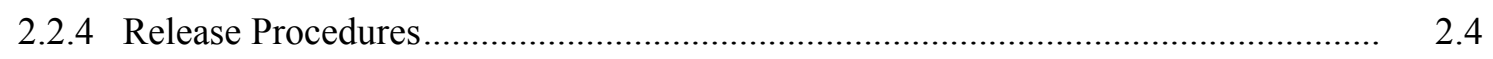

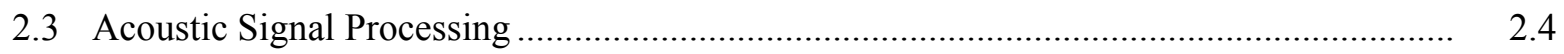

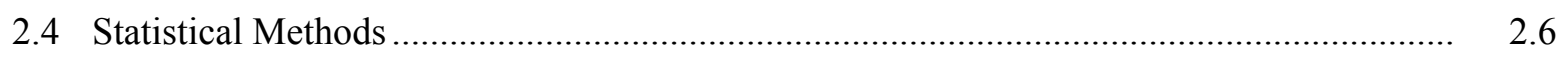

2.4.1 Estimation of Dam Passage Survival ........................................................... 2.6

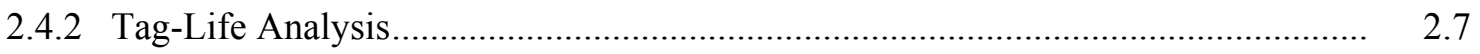

2.4.3 Tests of Assumptions ................................................................................. 2.7

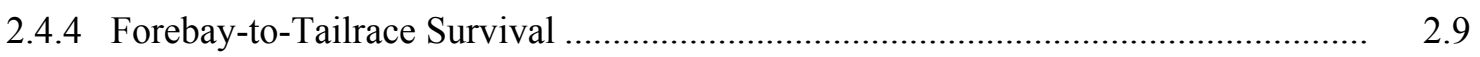

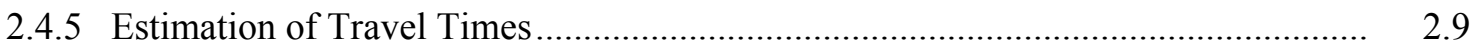

2.4.6 Estimation of Spill Passage Efficiency …........................................................... 2.9

2.4.7 Estimation of Fish Passage Efficiency ......................................................... 2.10

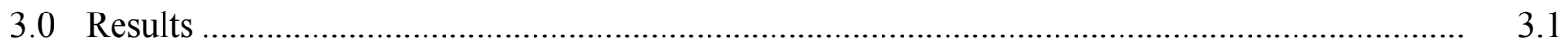

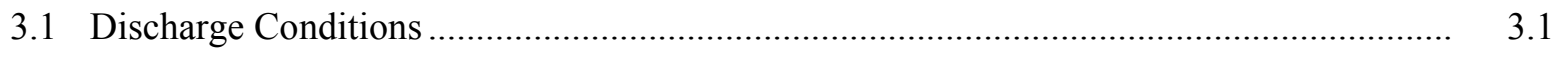

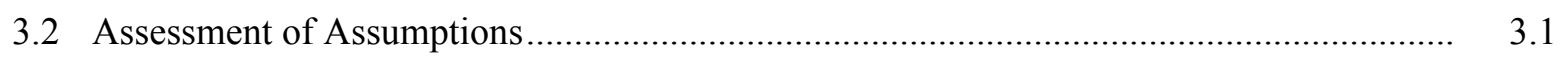

3.2.1 Examination of Tagger Effects.................................................................... 3.1

3.2.2 Examination of Tag-Lot Effects ..................................................................... 3.2

3.2.3 Handling Mortality and Tag Shedding ............................................................. 3.2

3.2.4 Examination of Tailrace Release Location Effects on Survival.............................. 3.2

3.2.5 Examination of Time In-river on Survivals of Different Release Groups ............... 3.3

3.2.6 Fish Size Distributions ....................................................................................... 3.3

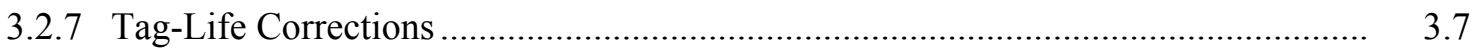

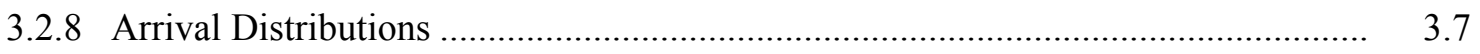

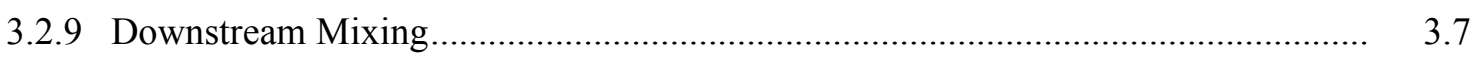

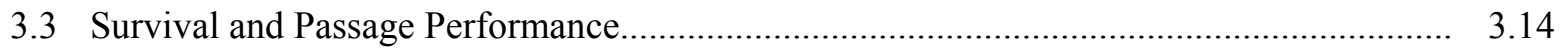


3.3.1 Dam Passage Survival ............................................................................... 3.14

3.3.2 Forebay-to-Tailrace Passage Survival ............................................................... 3.25

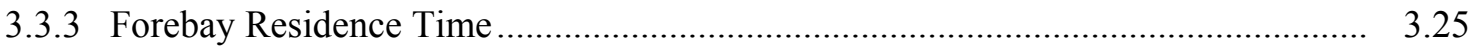

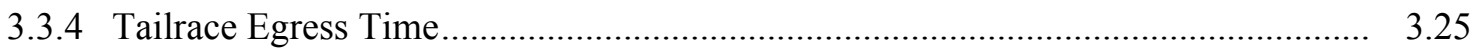

3.3.5 Spill Passage Efficiency ............................................................................... 3.25

3.3.6 Fish Passage Efficiency .............................................................................. 3.28

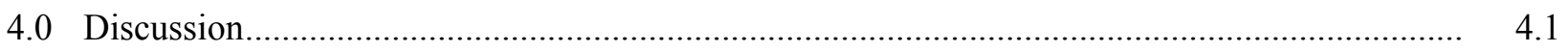

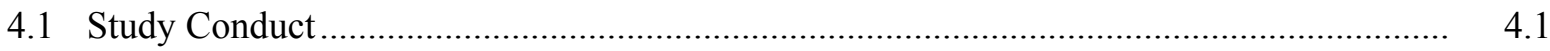

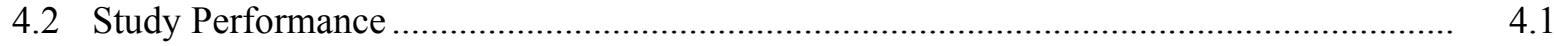

4.3 Comparison to Previous Acoustic Telemetry Studies .................................................... 4.1

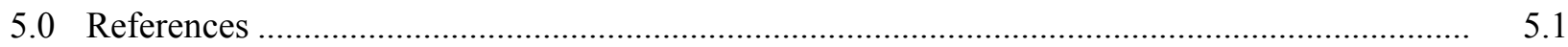

Appendix A - Tests of Assumptions …................................................................................. A.1

Appendix B - Capture Histories Used in Estimating Dam Passage Survival.................................. B.1 


\section{Figures}

2.1 Schematic of the virtual/paired-release design used to estimate dam passage survival at John Day Dam. The virtual release was composed of fish that arrived to the dam face from the release at rkm 390

2.2 Front view schematic of hydrophone deployments at three turbines showing the doubledetection arrays

3.1 Daily average total discharge and percent spill at John Day Dam during the spring 2011 JSATS yearling Chinook salmon and steelhead study, 27 April to 29 May 2011

3.2 Distributions of tailrace detections of $V_{1}$ fish on autonomous nodes, numbers of fish released in the tailrace at five locations, and survival rates by tailrace release location

3.3 Relative frequency distributions for fish lengths of yearling Chinook salmon smolts used in release $V_{1}$, release $R_{2}$, release $R_{3}$, and ROR fish sampled at John Day Dam by the Fish Passage Center.

3.4 Relative frequency distributions for fish lengths of steelhead smolts used in release $V_{1}$, release $R_{2}$, release $R_{3}$, and ROR fish sampled at John Day Dam by the Fish Passage Center.....

3.5 Range and median lengths of acoustically tagged yearling Chinook salmon andsteelhead used in the 2011 survival studies

3.6 Observed time of tag failure and fitted survivorship curves using the vitality model of Li and Anderson for tag lot 1, tag lot 2, and tag lots 3-5.

3.7 Comparison of fitted survivorship curves using the vitality model of Li and Anderson for JSATS tag lots 1, 2, and 3-5 used in the 2011 compliance studies.

3.8 Plots of the fitted tag-life survivorship curve and the arrival-time distributions of Yearling Chinook salmon smolts and steelhead smolts for releases $V_{1}, R_{2}$, and $R_{3}$ at the acousticdetection array located at rkm 86.0

3.9 Frequency distribution plots of downstream arrival timing for yearling Chinook salmon releases $V_{1}, R_{2}$, and $R_{3}$ at detection arrays located at rkm 309, rkm 275, rkm 234, rkm 161, rkm 113, and rkm 86 .

3.10 Frequency distribution plots of downstream arrival timing for steelhead releases $V_{1}, R_{2}$, and $R_{3}$ at detection arrays located at rkm $309, \mathrm{rkm} 275, \mathrm{rkm} 234, \mathrm{rkm} 161, \mathrm{rkm} 113$, and rkm $86 \ldots$.

3.11 Distribution of forebay residence times for yearling Chinook salmon and steelhead smolts at John Day Dam, 2011.

3.12 Distribution of tailrace egress times for yearling Chinook salmon and steelhead smolts at John Day Dam, 2011. 


\section{Tables}

ES.1 Estimates of dam passage survival at John Day Dam in 2011 ........................................... v

ES.2 Fish Accords performance measures at John Day Dam in 2011 .......................................... vi

ES.3 Survival study measures ............................................................................................ vii

2.1 Sample sizes of acoustically tagged fish releases used in the yearling Chinook salmon and

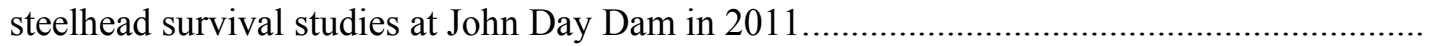

2.2 Relative release times for the acoustically tagged fish to accommodate downstream mixing. Releases were timed to accommodate the approximately $39-\mathrm{h}$ travel time between $R_{1}$ and $R_{2}$ and the 9-h travel time between $R_{2}$ and $R_{3}$.

3.1 Estimated probabilities of an acoustic tag being active at a downstream detection site for yearling Chinook salmon smolts and steelhead smolts by tag lot and release group

3.2 Survival, detection, and $\lambda$ parameters for final model used to estimate dam passage survival for yearling Chinook salmon during the early part of the spring study for $30 \%$ spill conditions......

3.3 Survival, detection, and $\lambda$ parameters for final model used to estimate dam passage survival for yearling Chinook salmon during the early part of the spring study for $40 \%$ spill conditions.

3.4 Survival, detection, and $\lambda$ parameters for the final model used to estimate dam passage survival for yearling Chinook salmon during the latter part of the spring study...

3.5 Survival, detection, and $\lambda$ parameters for the final model used to estimate dam passage survival for yearling Chinook salmon during the entire spring study.....

3.6 Survival, detection, and $\lambda$ parameters for the final model used to estimate dam passage survival for steelhead during the early part of the spring study for $30 \%$ spill conditions

3.7 Survival, detection, and $\lambda$ parameters for the final model used to estimate dam passage survival for steelhead during the early part of the spring study for $40 \%$ spill conditions

3.8 Survival, detection, and $\lambda$ parameters for the final model used to estimate dam passage survival for steelhead during the latter part of the spring study

3.9 Survival, detection, and $\lambda$ parameters for the final model used to estimate dam passage survival for steelhead during the entire spring study.....

3.10 Estimated mean and median forebay residence times and mean and median tailrace egress times for yearling Chinook salmon and steelhead smolts at John Day Dam in 2011.

4.1 Comparison of dam-passage survival estimates based on paired-release models 2008 and 2011.

4.2 Single-release estimates of dam-passage survival in 2009 and 2010......

4.3 Comparison of passage metrics for yearling Chinook salmon

4.4 Comparison of passage metrics for juvenile steelhead 


\subsection{Introduction}

The compliance monitoring study reported here was conducted by researchers at Pacific Northwest National Laboratory (PNNL) and the University of Washington for the U.S. Army Corps of Engineers, Portland District (USACE) in spring 2011. The purpose of the study was to estimate dam passage survival at John Day Dam as stipulated by the 2008 Federal Columbia River Power System (FCRPS) Biological Opinion (BiOp) and provide additional performance measures at the dam as stipulated in the Columbia Basin Fish Accords for yearling Chinook salmon and steelhead (3 Treating Tribes-Action Agencies 2008).

\subsection{Background}

The FCRPS 2008 BiOp contains a reasonable and prudent alternative (RPA) that includes actions calling for measurements of juvenile salmonid survival (RPAs 52.1 and 58.1). These RPAs are being addressed as part of the federal research, monitoring, and evaluation (RME) effort for the FCRPS BiOp. Most importantly, the FCRPS BiOp includes performance standards for juvenile salmonid survival in the FCRPS against which the Action Agencies (Bonneville Power Administration, Bureau of Reclamation, and USACE) must compare their estimates, as follows (after the RME Strategy 2 of the RPA):

Juvenile Dam Passage Performance Standards - The Action Agencies juvenile performance standards are an average across Snake River and lower Columbia River dams of $96 \%$ average dam passage survival for spring Chinook and steelhead and 93\% average across all dams for Snake River subyearling Chinook. Dam passage survival is defined as survival from the upstream face of the dam to a standardized reference point in the tailrace.

The Memorandum of Agreement between the three lower river tribes and the Action Agencies (known informally as the Fish Accords), contains three additional requirements relevant to the 2011 survival studies (after Attachment A to the memorandum of agreement):

Dam Survival Performance Standard - Meet the 96\% dam passage survival standard for yearling Chinook and steelhead and the $93 \%$ standard for subyearling Chinook. Achievement of the standard is based on 2 years of empirical survival data ....

Spill Passage Efficiency and Delay Metrics - Spill passage efficiency (SPE) and delay metrics under current spill conditions ... are not expected to be degraded ("no backsliding") with installation of new fish passage facilities at the dams ....

Future RME - The Action Agencies' dam survival studies for purposes of determining juvenile dam passage performance will also collect information about SPE, BRZ-to-BRZ (boat-restricted zone) survival and delay, as well as other distribution and survival information. SPE and delay metrics will be considered in the performance check-ins or with Configuration and Operations Plan updates, but not as principal or priority metrics over dam survival performance standards. Once a dam meets the survival performance standard, SPE and delay metrics may be monitored coincidentally with dam survival testing. 
This report summarizes the results of the 2011 spring acoustic-telemetry study of yearling Chinook salmon and steelhead at John Day Dam to assess the Action Agencies' compliance with the performance criteria of the BiOp and Fish Accords.

\subsection{Study Objectives}

The purpose of spring 2011 compliance monitoring at John Day Dam was to estimate performance measures for yearling Chinook salmon and steelhead smolts as outlined in the FCRPS BiOp and Fish Accords. For each fish stock, the following metrics were estimated using the Juvenile Salmon Acoustic Telemetry System (JSATS) technology:

- Dam passage survival, defined as survival from the upstream face of the dam to a standardized reference point in the tailrace. Performance ${ }^{1}$ should be $\geq 96 \%$ survival for spring stocks (i.e., yearling Chinook salmon and steelhead). Survival should be estimated with a standard error (SE) $\leq 1.5 \%$.

- Forebay-to-tailrace survival, defined as survival from a forebay array $2 \mathrm{~km}$ upstream of the dam to a tailrace array $3 \mathrm{~km}$ downstream. The forebay-to-tailrace survival estimate satisfies the "BRZ-toBRZ" survival estimated called for in the Fish Accords.

- Forebay residence time, defined as the average time smolts take to travel from the forebay BRZ $2 \mathrm{~km}$ upstream of the dam to the entrance into the dam.

- Tailrace egress time, defined as the average time smolts take to travel from the dam to the downstream tailrace boundary, i.e., tailrace array $3 \mathrm{~km}$ downstream of the dam.

- SPE, defined as the fraction of fish going through the dam via the spillway. ${ }^{2}$

- Fish passage efficiency (FPE), defined as the fraction of fish going through the dam via the spillway and the sluiceway. ${ }^{3}$

The intent of the 2011 spring study was to assess compliance with the dam passage survival standard under 30\% and $40 \%$ spill conditions. The high river flow conditions during spring 2011 disrupted the study, preventing the alternative spill regime from being performed and replicated during the latter half of the investigation. As such, survival results are presented for the first part of the study, when alternative spill conditions were able to be performed, and for the prevailing conditions during the second half of the spill study.

Results are reported for the two fish stocks by performance measure. This report is designed to provide a succinct and timely summary of $\mathrm{BiOp} /$ Fish Accords performance measures. A subsequent, comprehensive technical report scheduled for 2012 will provide more detailed data about survival and fish passage for yearling Chinook salmon and steelhead at John Day Dam in 2011.

\footnotetext{
${ }^{1}$ Performance as defined in the 2008 FCRPS BiOp, Section 6.0.

${ }^{2}$ The definition of spill passage efficiency in the Fish Accords has traditionally been called fish passage efficiency.

${ }^{3}$ This was called spill passage efficiency in the Fish Accords.
} 


\subsection{Methods}

Study methods involved fish release and recapture; the associated fish handling, tagging, and release procedures; acoustic signal processing; and statistical and analytical approaches.

\subsection{Release-Recapture Design}

The release-recapture design used to estimate dam passage survival at John Day Dam consisted of a novel combination of a virtual release $\left(V_{1}\right)$ of fish at the face of the dam and a paired release below the dam (Figure 2.1) (Skalski et al. 2010a, 2010b). Tagged fish were released above John Day Dam to supply a source of fish known to have arrived alive at the face of the dam. By releasing the fish far enough upstream, they should have arrived at the dam in a spatial pattern typical of run-of-river (ROR) fish. This virtual-release group was then used to estimate survival through the dam and part of the way through the next reservoir (i.e., river kilometer [rkm] 325) (Figure 2.1). To account and adjust for this extra reach mortality, a paired release below John Day Dam (i.e., $R_{2}$ and $R_{3}$ ) (Figure 2.1) was used to estimate survival in that segment of the reservoir below the dam. Dam passage survival was then estimated as the quotient of the survival estimates for the virtual release to that of the paired release. The sizes of the releases of the acoustically tagged fish used in the dam passage survival estimates are summarized in Table 2.1.

Table 2.1. Sample sizes of acoustically tagged fish releases used in the yearling Chinook salmon and steelhead survival studies at John Day Dam in 2011.

\begin{tabular}{lcc}
\hline \multicolumn{1}{c}{ Release Location } & $\begin{array}{c}\text { Yearling } \\
\text { Chinook Salmon }\end{array}$ & Steelhead \\
\hline Above John Day $\left(R_{1}\right)$ & 2510 & 2587 \\
Virtual Release $\left(V_{1}\right)$ & 2441 & 2469 \\
John Day Dam Tailrace $\left(R_{2}\right)$ & 1193 & 1196 \\
Bonneville Reservoir $\left(R_{3}\right)$ & 799 & 797 \\
\hline
\end{tabular}

The same release-recapture design was also used to estimate forebay-to-tailrace survival, except that the virtual-release group was constructed of fish known to have arrived at the forebay array (rkm 325). The same below-dam paired release was used to adjust for the extra release mortality below the dam as was used to estimate dam passage survival. The double-detection arrays at the face of the dam (Figure 2.2) were analyzed as two independent arrays to allow estimation of detection probabilities by route of passage and assigned the location of the last detection, i.e., the passage route. These passageroute data were used to calculate SPE and FPE at John Day Dam. The fish used in the virtual release at the face of the dam were used to estimate tailrace egress time. 


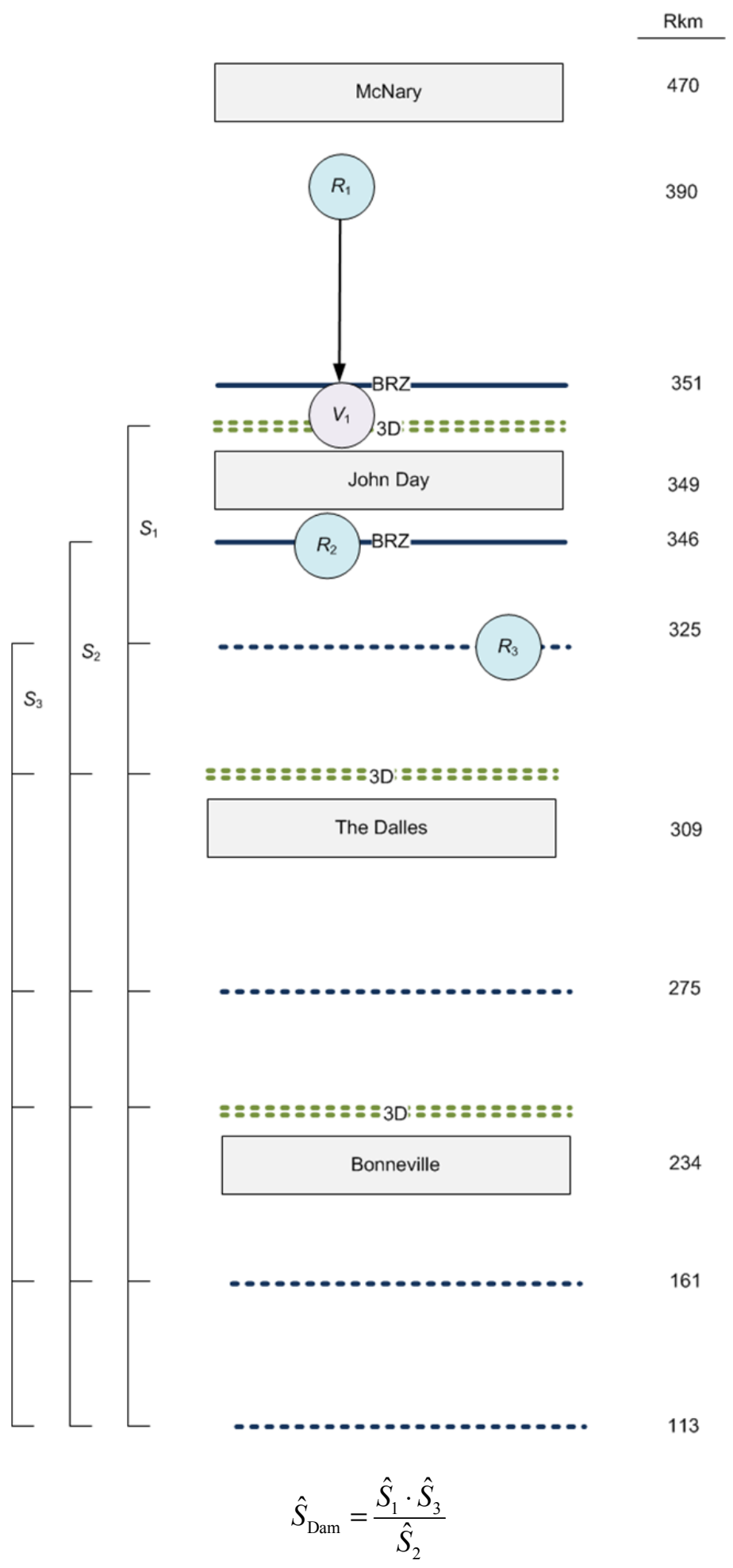

Figure 2.1. Schematic of the virtual/paired-release design used to estimate dam passage survival at John Day Dam. The virtual release $\left(V_{1}\right)$ was composed of fish that arrived to the dam face from the release at rkm 390. The below-dam release pair was composed of releases $R_{2}$ and $R_{3}$ with detection arrays used in the survival analysis denoted by dashed lines. 


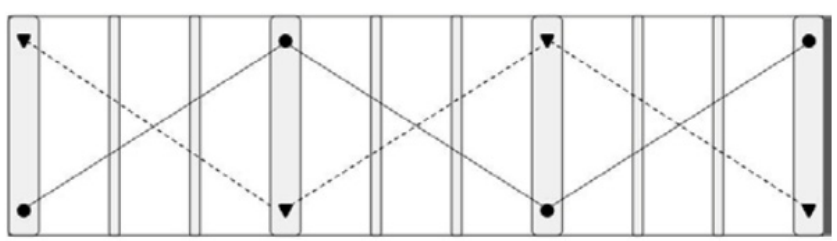

Figure 2.2. Front view schematic of hydrophone deployments at three turbines showing the doubledetection arrays. The circles denote the hydrophones of Array 1 and the triangles denote the hydrophones of Array 2.

Three distinct manufacturing lots of tags were used during the spring 2011 JSATS study, (i.e., 1, 2, 3-5). From each of these tag lots, approximately 50 tags (i.e., 50, 50, and 59, respectively) were randomly sampled to be used in tag-life assessments. The tags were activated, held in river water, and monitored continuously until they failed. The information from the tag-life study was used to adjust the perceived survival estimates from the Cormack-Jolly-Seber release-recapture model according to the methods of Townsend et al. (2006).

\subsection{Handling, Tagging, and Release Procedures}

Fish obtained from the John Day Dam juvenile bypass system were surgically implanted with JSATS tags, and then transported to three different release points, as described in the following sections.

\subsubsection{Acoustic Tags}

The acoustic tags used in the spring 2011 study were manufactured by Advanced Telemetry Systems (ATS). Each tag, model number ATS-156dB, measured $12.02 \mathrm{~mm}$ in length, $5.21 \mathrm{~mm}$ in width, $3.72 \mathrm{~mm}$ in thickness, and weighed $0.430 \mathrm{~g}$ in air. The tags had a nominal transmission rate of 1 pulse every $3 \mathrm{~s}$. Nominal tag life was expected to be about 25 days.

\subsubsection{Fish Source}

The yearling Chinook salmon and steelhead used in the study were all obtained from the John Day Dam juvenile bypass system. The Pacific States Marine Fisheries Commission diverted fish from the juvenile bypass system into an examination trough, as described by Martinson et al. (2006). Fish $\geq 95 \mathrm{~mm}$ in length without malformations or excessive descaling $(>20 \%)$ were selected for tagging.

\subsubsection{Tagging Procedure}

The fish to be tagged were anesthetized in an 18.9-L "knockdown" bucket with fresh river water and MS-222 (tricaine methanesulfonate; 80 to $100 \mathrm{mg} / \mathrm{L}$ ). Anesthesia buckets were refreshed repeatedly to maintain the temperature within $\pm 2{ }^{\circ} \mathrm{C}$ of current river temperatures. Each fish was weighed and measured before tagging.

During surgery, each fish was placed ventral side up and a gravity-fed anesthesia supply line was placed into its mouth. The dilution of the "maintenance" anesthesia was $40 \mathrm{mg} / \mathrm{L}$. Using a surgical blade, a 6- to 8-mm incision was made in the body cavity between the pelvic girdle and pectoral fin. A 
passive integrated transponder (PIT) tag was inserted followed by an acoustic tag. Both tags were inserted toward the anterior end of the fish. The incision was closed using 5-0 Monocryl suture.

After closing the incision, the fish were placed in a dark 18.9-L transport bucket filled with aerated river water. Fish were held in these buckets for 18 to $24 \mathrm{~h}$ before being transported for release into the river. The loading rate was five fish per bucket.

\subsubsection{Release Procedures}

All fish were tagged at John Day Dam and transported by truck to the release locations (Figure 2.1). Transportation routes were adjusted to provide equal travel times to each release location from John Day Dam. Upon arriving at a release site, fish buckets were transferred to a boat for transport to the in-river release location. There were five release locations at each release site across the river (Figure 2.1), and equal numbers of buckets of fish were released at each of the five locations.

Releases occurred for 34 consecutive days (from 26 April to 29 May 2011). Releases alternated between daytime and nighttime, every other day, over the course of the study. The timing of the releases at the release sites was staggered to help facilitate downstream mixing (Table 2.2).

Table 2.2. Relative release times for the acoustically tagged fish to accommodate downstream mixing. Releases were timed to accommodate the approximately 39-h travel time between $R_{1}$ and $R_{2}$ and the 9-h travel time between $R_{2}$ and $R_{3}$.

\begin{tabular}{ccc}
\hline & \multicolumn{2}{c}{ Relative Release Times } \\
\cline { 2 - 3 } Release Location & Daytime Start & Nighttime Start \\
\hline$R_{1}(\mathrm{rkm} 390)$ & Day 1: 0800 & Day 1: 2000 \\
$R_{2}(\mathrm{rkm} 346)$ & Day 2: 2300 & Day 3: 1100 \\
$R_{3}(\mathrm{rkm} 325)$ & Day 3: 0800 & Day 3: 2000 \\
\hline
\end{tabular}

\subsection{Acoustic Signal Processing}

Transmissions of JSATS tag codes received on cabled and autonomous hydrophones were recorded in raw data files. These files were downloaded periodically and transported to PNNL's North Bonneville offices for processing. Receptions of tag codes within raw data files were processed to produce a data set of accepted tag-detection events. For cabled arrays, detections from all hydrophones at a dam were combined for processing. The following three filters were used:

- Multipath filter: For data from each individual cabled hydrophone, all tag-code receptions that occur within $0.156 \mathrm{~s}$ after an initial identical tag code reception were deleted under the assumption that closely lagging signals are multipath. Initial code receptions were retained. The delay of $0.156 \mathrm{~s}$ was the maximum acceptance window width for evaluating a pulse repetition interval (PRI) and was computed as 2(PRI_Window+12×PRI_Increment). Both PRI_Window and PRI_Increment were set at $0.006 \mathrm{~s}$, which was chosen to be slightly larger than the potential rounding error in estimating PRI to two decimal places. 
- Multi-detection filter: Receptions were retained only if the same tag code was received at another hydrophone in the same array within $0.3 \mathrm{~s}$ because receptions on separate hydrophones within $0.3 \mathrm{~s}$ (about $450 \mathrm{~m}$ of range) were likely from a single tag transmission.

- PRI filter: Only those series of receptions of a tag code (or "messages") that were consistent with the pattern of transmissions from a properly functioning JSATS acoustic tag were retained. Filtering rules were evaluated for each tag code individually, and it was assumed that only a single tag would be transmitting that code at any given time. For the cabled system, the PRI filter operated on a message, which included all receptions of the same transmission on multiple hydrophones within $0.3 \mathrm{~s}$. Message time was defined as the earliest reception time across all hydrophones for that message. Detection required that at least six messages were received with an appropriate time interval between the leading edges of successive messages.

The receptions of JSATS tag codes within raw data files from autonomous nodes were also processed to produce a data set of accepted tag-detection events, or events for short. A single file was processed at a time, and no information about receptions at other nodes was used. The Multipath and PRI filters described above were used.

The output of this process was a data set of events that summarized accepted tag detections for all times and locations where hydrophones were operating. Each unique event record included a basic set of fields that indicated the unique identification number of the fish, the first and last detection time for the event, the location of detection, and how many messages were detected within the event. This list was combined with accepted tag detections from the autonomous arrays and PIT-tag detections for additional quality assurance/quality control analysis prior to survival analysis. Additional fields capture specialized information, where available. One such example was route of passage, which was assigned a value for those events that immediately precede passage at a dam based on spatial tracking of tagged fish movements to a location of last detection. Multiple receptions of messages within an event can be used to triangulate successive tag position relative to hydrophone locations.

One of the most important quality control steps was to examine the chronology of detections of every tagged fish on all arrays above and below the dam-face array to identify any detection sequences that deviate from the expected upstream to downstream progression through arrays in the river. Except for possible detections on forebay entrance arrays after detection on a nearby dam-face array 1 to $3 \mathrm{~km}$ downstream, apparent upstream movements of tagged fish between arrays that were greater than $5 \mathrm{~km}$ apart or separated by one or more dams were very rare $(<0.015 \%)$ and probably represented false positive detections on the upstream array. False positive detections usually will have close to the minimum number of messages and were deleted from the event data set before survival analysis.

Three-dimensional (3D) tracking of JSATS-tagged fish in the immediate forebay of John Day Dam was used to determine routes of passage to estimate SPE. Acoustic tracking is a common technique in bioacoustics based on time-of-arrival differences among different hydrophones. Usually, the process requires a three-hydrophone array for two-dimensional tracking and a four-hydrophone array for 3D tracking. For this study, only 3D tracking was performed. The methods were similar to those described by Weiland et al. (2011). 


\subsection{Statistical Methods}

Statistical methods were used to test assumptions and estimate passage survival, tag life, forebay-totailrace survival, travel times, SPE, and FPE, as described below.

\subsubsection{Estimation of Dam Passage Survival}

Maximum likelihood estimation was used to estimate dam passage survival at John Day Dam based on the virtual/paired-release design. The capture histories from all the replicate releases, both daytime and nighttime, were pooled to produce the estimate of dam passage survival. A joint likelihood model was constructed of a product multinomial with separate multinomial distributions describing the capture histories of the separate release groups (i.e., $V_{1}, R_{2}$, and $R_{3}$ ) and differentiated by tag lot. The major manufacturing lots (i.e., 1, 2, 3-5) had separately estimated tag-life corrections but, it was assumed, common reach survival parameters across tag lots for fish from a release location.

The joint likelihood used to model the three release groups was initially fully parameterized. Each of the three releases was allowed to have unique survival and detection parameters. If precision was adequate (i.e., $S E \leq 0.015$ ) with the fully parameterized model, no further modeling was performed. If initial precision was inadequate, then likelihood ratio tests were used to assess homogeneity of parameters across release groups to identify the best parsimonious model to describe the capture history data. This approach was used to help preserve both precision and robustness of the survival results. All calculations were performed using Program ATLAS (http://www.cbr.washington.edu/paramest/atlas/).

Dam passage survival was estimated by the function

$$
\hat{S}_{\text {Dam }}=\frac{\hat{S}_{1}}{\left(\frac{\hat{S}_{2}}{\hat{S}_{3}}\right)}=\frac{\hat{S}_{1} \cdot \hat{S}_{3}}{\hat{S}_{2}}
$$

where $\hat{S}_{i}$ is the tag-life-corrected survival estimate for the $i$ th release group $(i=1, \ldots, 3)$. The variance of $\hat{S}_{\text {Dam }}$ was estimated in a two-step process that incorporated both the uncertainty in the tag-life corrections and the release-recapture processes.

In 2011, compliance tests at John Day Dam were planned for dam operation conditions that included either $30 \%$ or $40 \%$ spill. High flow conditions in spring 2011 interrupted the alternating two-day spill events. Consequently, a post-facto approach to examining dam passage survival during spring 2011 was necessary. Four alternative estimates of dam passage survival were computed as follows:

1. Survival during $30 \%$ spill - early season (27 April - 16 May 2011)

2. Survival during $40 \%$ spill - early season (27 April - 16 May 2011)

3. Survival during the late season (16 May - 29 May 2011)

4. Season-wide survival (27 April - 29 May 2011). 
During the planned spill study, spill conditions were changed at 8 p.m. on transition days. Fish used in forming the virtual-release groups $\left(V_{1}\right)$ at the face of the dam excluded all detections occurring between $7-9$ p.m. in order for a clean distinction between $30 \%$ and $40 \%$ spill conditions.

In estimating dam passage survival during a particular segment of the study, all fish in releases $R_{2}$ and $R_{3}$ (see Figure 2.1) during the period regardless of spill conditions were used in the analyses. This procedure was based on the premise that the tailrace BRZ demarks the point below which tailrace conditions have no influence on fish survival or travel times.

\subsubsection{Tag-Life Analysis}

For each of the three major manufacturing lots of JSATS tags (i.e., 1, 2, 3-5), 50 to 59 acoustic tags were systematically sampled over the course of the yearling Chinook salmon and steelhead smolt tagging process. The tags were continuously monitored from activation to failure in ambient river water. For each tag lot, the failure times were fit to the four-parameter vitality model of Li and Anderson (2009). The vitality model tends to fit acoustic-tag failure times well, because it allows for both early onset of random failure due to manufacturing as well as systematic battery failure later on.

The survivorship function for the vitality model can be rewritten as

$$
S(t)=1-\left(\Phi\left(\frac{1-r t}{\sqrt{u^{2}+s^{2} t}}\right)-e^{\left(\frac{2 u^{2} r^{2}}{s^{4}}+\frac{2 r}{s^{2}}\right)} \Phi\left(\frac{2 u^{2} r+r t+1}{\sqrt{u^{2}+s^{2} t}}\right)\right)^{e^{-k t}}
$$

where

$$
\begin{aligned}
\Phi & =\text { cumulative normal distribution } \\
r & =\text { average wear rate of components, } \\
s & =\text { standard deviation in wear rate } \\
k & =\text { rate of accidental failure } \\
u & =\text { standard deviation in quality of original components. }
\end{aligned}
$$

The random failure component, in addition to battery discharge, gives the vitality model additional latitude to fit tag-life data not found in other failure-time distributions such as the Weibull or Gompertz. Parameter estimation was based on maximum likelihood estimation.

For the virtual-release group $\left(V_{1}\right)$ based on fish known to have arrived at the dam and with active tags, the conditional probability of tag activation, given the tag was active at the detection array at $\mathrm{rkm} 349$, was used in the tag-life adjustment for that release group. The conditional probability of tag activation at time $t_{1}$, given it was active at time $t_{0}$, was computed by the quotient:

$$
P\left(t_{1} \mid t_{0}\right)=\frac{S\left(t_{1}\right)}{S\left(t_{0}\right)}
$$

\subsubsection{Tests of Assumptions}

Approaches to assumption testing are described below. 


\subsubsection{Burnham et al. (1987) Tests}

Tests 2 and 3 of Burnham et al. (1987) have been used to assess whether upstream detection history has an effect on downstream survival. Such tests are most appropriate when fish are physically recaptured or segregated during capture as in the case with PIT-tagged fish going through the juvenile bypass system. However, acoustic-tag studies do not use physical recaptures to detect fish.

Consequently, there is little or no relevance of these tests in acoustic-tag studies. Furthermore, the very high detection probabilities present in acoustic-tag studies frequently preclude calculation of these tests. For these reasons, these tests were not performed.

\subsubsection{Tests of Mixing}

Evaluation of homogeneous arrival of release groups at downriver detection sites was based on graphs of arrival distributions. The graphs were used to identify any systematic and meaningful departures from mixing. Ideally, the arrival distributions should overlap one another with similarly timed modes.

\subsubsection{Tagger Effects}

Subtle differences in handling and tagging techniques can have an effect on the survival of acoustically tagged smolts used in the estimation of dam passage survival. For this reason, tagger effects were evaluated. The single release-recapture model was used to estimate reach survivals for fish tagged by different individuals. The analysis evaluated whether any consistent pattern of reduced reach survivals existed for fish tagged by any of the tagging staff.

For $k$ independent reach survival estimates, a test of equal survival was performed using the $F$-test

$$
F_{k-1, \infty}=\frac{s_{\hat{S}}^{2}}{\left(\frac{\left.\sum_{i=1}^{k} \widehat{\operatorname{Var}}\left(\hat{S}_{i} \mid S_{i}\right)\right)}{k}\right)}
$$

where

$$
s_{\hat{S}}^{2}=\frac{\sum_{i=1}^{k}\left(\hat{S}_{i}-\hat{\bar{S}}\right)^{2}}{k-1}
$$

and

$$
\hat{\bar{S}}=\frac{\sum_{i=1}^{k} \hat{S}_{i}}{k}
$$

The $F$-test was used in evaluating tagger effects as well as tag-lot effects. 


\subsubsection{Forebay-to-Tailrace Survival}

The same virtual/paired-release methods used to estimate dam passage were also used to estimate forebay-to-tailrace survival. The only distinction was the virtual-release group $\left(V_{1}\right)$ was composed of fish known to have arrived alive at the forebay array (rkm 351) of John Day Dam instead of at the dam face (Figure 2.1).

\subsubsection{Estimation of Travel Times}

Travel times associated with forebay residence time and tailrace egress were estimated using arithmetic averages as specified in the Fish Accords, i.e.,

$$
\bar{t}=\frac{\sum_{i=1}^{n} t_{i}}{n}
$$

with the variance of $\bar{t}$ estimated by

$$
\widehat{\operatorname{Var}}(\bar{t})=\frac{\sum_{i=1}^{n}\left(t_{i}-\bar{t}\right)^{2}}{n(n-1)},
$$

and where $t_{i}$ was the travel time of the $i^{\text {th }}$ fish $(i=1, \ldots, n)$. Median travel times were also computed and reported.

The estimated tailrace egress time was based on the time from last detection of a fish at the double array at the dam face at John Day Dam to the last detection at the tailrace array $3 \mathrm{~km}$ downstream of the dam ( $\mathrm{rkm}$ 346). The estimated forebay residence times were based on the time from the first detection at the forebay BRZ array $2 \mathrm{~km}$ above the dam to the last detection at the double array in front of John Day Dam.

\subsubsection{Estimation of Spill Passage Efficiency}

SPE was estimated by the fraction

$$
\widehat{\mathrm{SPE}}=\frac{\hat{N}_{N T S W}+\hat{N}_{T S W}}{\hat{N}_{N T S W}+\hat{N}_{T S W}+\hat{N}_{T U R}+\hat{N}_{J B S}},
$$

where $\hat{N}_{i}$ is the estimated abundance of acoustic-tagged fish through the $i$ th route ( $i=$ non-TSW [NTSW], temporary spill weir [TSW], turbines [TUR], and juvenile bypass system [JBS]). The double- 
detection array was used to estimate absolute abundance $(N)$ through a route using the single markrecapture model (Seber 1982:60) independently at each route. Calculating the variance in stages, the variance of $\widehat{\mathrm{SPE}}$ was estimated as

$$
\begin{aligned}
\operatorname{Var}(\widehat{\mathrm{SPE}})= & \frac{\widehat{\mathrm{SPE}}(1-\widehat{\mathrm{SPE}})}{\sum_{i=1}^{4} \hat{N}_{i}}+\widehat{\mathrm{SPE}}^{2}(1-\widehat{\mathrm{SPE}})^{2} \\
& \cdot\left[\frac{\operatorname{Var}\left(\hat{N}_{N T S W}\right)+\operatorname{Var}\left(\hat{N}_{T S W}\right)}{\left(\hat{N}_{N T S W}+\hat{N}_{T S W}\right)^{2}}+\frac{\widehat{\operatorname{Var}}\left(\hat{N}_{T U R}\right)+\operatorname{Var}\left(\hat{N}_{J B S}\right)}{\left(\hat{N}_{T U R}+\hat{N}_{J B S}\right)^{2}}\right] .
\end{aligned}
$$

\subsubsection{Estimation of Fish Passage Efficiency}

$\mathrm{FPE}^{1}$ was estimated by the fraction

$$
\widehat{\mathrm{FPE}}=\frac{\hat{N}_{N T S W}+\hat{N}_{T S W}+\hat{N}_{J B S}}{\hat{N}_{N T S W}+\hat{N}_{T S W}+\hat{N}_{J B S}+\hat{N}_{T U R}},
$$

Calculating the variance in stages, the variance of $\widehat{\mathrm{FPE}}$ was estimated as

$$
\begin{aligned}
\operatorname{Var}(\widehat{\mathrm{FPE}})= & \frac{\widehat{\mathrm{FPE}}(1-\widehat{\mathrm{FPE}})}{\sum_{i=1}^{4} \hat{N}_{i}}+\widehat{\mathrm{FPE}}^{2}(1-\widehat{\mathrm{FPE}})^{2} \\
& \cdot\left[\frac{\operatorname{Var}\left(\hat{N}_{N T S W}\right)+\operatorname{Var}\left(\hat{N}_{T S W}\right)+\operatorname{Var}\left(\hat{N}_{J B S}\right)}{\left(\hat{N}_{N T S W}+\hat{N}_{T S W}+\hat{N}_{J B S}\right)^{2}}+\frac{\widehat{\operatorname{Var}}\left(\hat{N}_{T U R}\right)}{\hat{N}_{T U R}^{2}}\right] .
\end{aligned}
$$

For timely production of this report, SPE and FPE estimates were calculated from passage numbers assuming equal detection probabilities among routes and a binomial sampling model.

${ }^{1}$ FPE was called spill passage efficiency in the Fish Accords. 


\subsection{Results}

The results cover discharge conditions, tests of assumptions, and survival and passage estimates.

\subsection{Discharge Conditions}

From the onset of the spring study to about 14 May $2011,30 \%$ and $40 \%$ spill conditions were carefully generated in alternating 2-day test periods. After 15 May 2011, spill levels exceeded 40\% to the end of planned study period, disrupting plans to assess compliance under $30 \%$ and $40 \%$ spill conditions over the entire spring season (Figure 3.1).

As a consequence of the disruption of the $30 \%$ and $40 \%$ spill conditions due to high river flows, survival estimates were calculated during four different periods of time:

1. $30 \%$ spill conditions during the early season (27 April - 16 May 2011)

2. $40 \%$ spill conditions during the early season (27 April - 16 May 2011)

3. Late season (16 - 29 May 2011)

4. Season-wide (27 April - 29 May 2011).

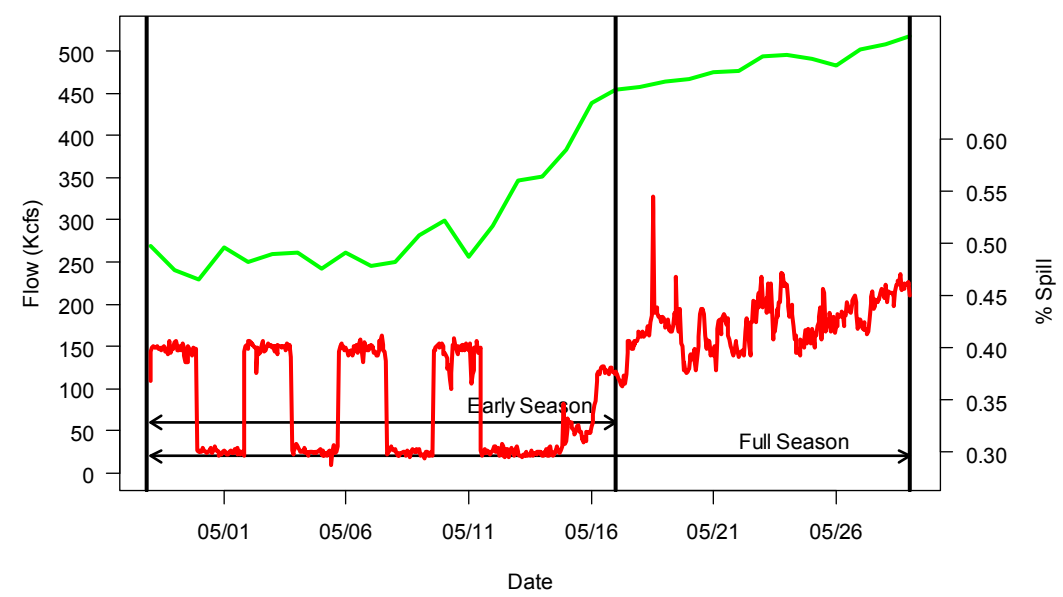

Figure 3.1. Daily average total discharge (kcfs) and percent spill at John Day Dam during the spring 2011 JSATS yearling Chinook salmon and steelhead study, 27 April to 29 May 2011.

\subsection{Assessment of Assumptions}

The assessment of assumptions covers tagger effects, tag-lot effects, delayed handling effects, fish size distributions, tag-life corrections, arrival distributions, and downstream mixing.

\subsubsection{Examination of Tagger Effects}

A total of eight different taggers assisted in tagging all of the yearling Chinook salmon and steelhead smolts associated with the JSATS survival studies at John Day, The Dalles, and Bonneville dams in spring 2011. Analyses found tagger effort was homogenously distributed either across all locations 
within a replicate release or within the project-specific releases within a replicate (Appendix A). Examination of reach survivals and cumulative survivals from above John Day Dam to below Bonneville Dam found no consistent or reproducible evidence that fish tagged by different staff members had different in-river survival rates (Appendix A). Therefore, fish tagged by all taggers were included in the estimation of survival and other performance measures.

\subsubsection{Examination of Tag-Lot Effects}

Three major tag lots (i.e., 1, 2, and 3-5) were used in the tagging of the yearling Chinook salmon and steelhead smolts during the 2011 JSATS investigations. Overall, tag lots were not homogeneously distributed across all release locations (Appendix A). However, they were homogeneously distributed within each of the below-dam paired releases (i.e., $R_{2}-R_{3}, R_{4}-R_{5}$, and $R_{6}-R_{7}$ ) used in the virtual/pairedrelease design (Appendix A).

After correcting for differences in tag life, there was no consistent or reproducible evidence to indicate differences in survival for fish tagged by the different tag lots (Appendix A). Therefore, fish tagged from all tag lots were used in the estimation of survival and other performance measures.

\subsubsection{Handling Mortality and Tag Shedding}

Fish were held for 24 to $36 \mathrm{~h}$ prior to release. The pre-release tagging mortality in spring was $0.17 \%$. No tags were shed during the 24 -h holding period.

\subsubsection{Examination of Tailrace Release Location Effects on Survival}

We explored the distribution of weighted detections of dam-passed fish ( $V_{1}-$ Figure 2.1$)$ fish on tailrace autonomous nodes relative to the distribution of reference releases among five locations in the tailrace and examined the effect of tailrace release location on single release survival rates to The Dalles Dam (Figure 3.2). The percent of fish detected on four autonomous nodes in the John Day tailrace was weighted to try and equalize sampling effort and detectability among node locations. Sampling effort varied because some nodes stopped sampling prematurely because of damage or they were lost. Detectability varied because it is inversely related to water velocities, which were highest on the Washington side of the channel and positively correlated with depth, which was greatest on the Oregon side of the channel. On each node, the percent of all yearling Chinook detection events with only the minimum number of tag-code receptions (4) was used to index detectability loss, and it was $25 \%$ at Location $1,10 \%$ at Location 2, 5\% at Location 3, and 1\% at Location 4. Percentages for juvenile steelhead were $25 \%$ at Location $1,10 \%$ at Location 2, 5\% at Location 3, and 5\% at Location 4.

The uniform distribution of fish releases among five locations in the tailrace appeared to be reasonable given the observed weighted distribution of detections of dam-passed fish ( $V_{1}$ - Figure 2.1). Fish that passed the dam were detected at only a slightly higher percentage detected on the Oregon side of the channel than they were on the Washington side. Survival rates by release location varied from 0.971 to 0.993 for yearling Chinook salmon smolts and from 0.963 to 0.994 for juvenile steelhead. Wide and overlapping $95 \%$ confidence intervals suggest that point estimates of survival rates did not differ significantly among release locations. Low precision is expected given sample sizes that ranged from 208 to 260 fish. 


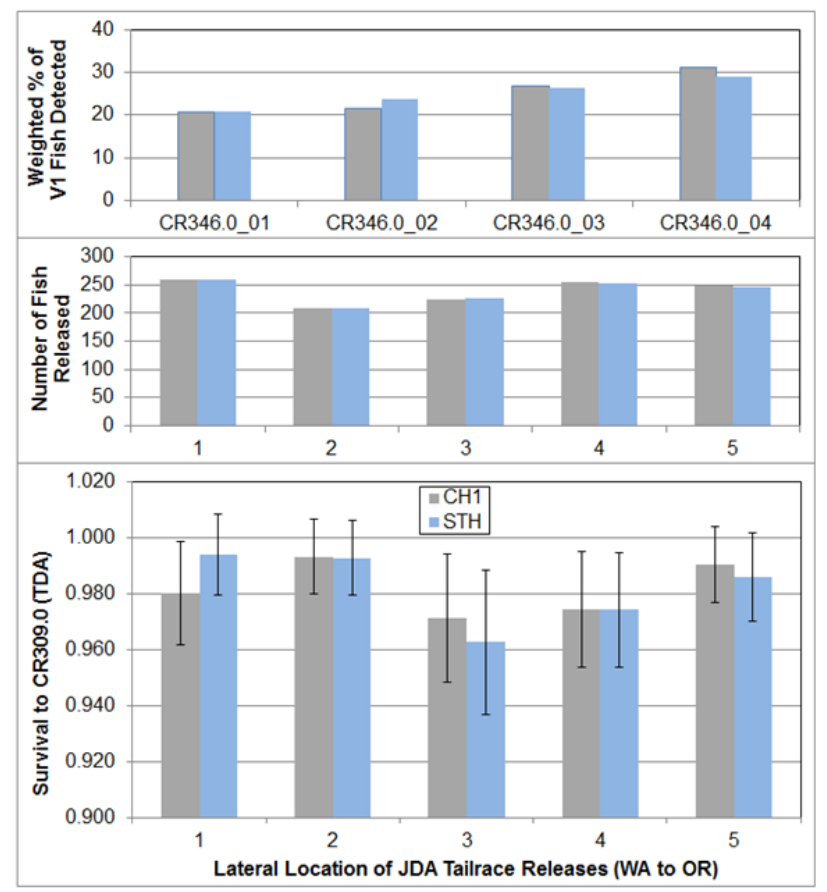

Figure 3.2. Distributions of tailrace detections of $V_{1}$ fish on autonomous nodes (top), numbers of fish released in the tailrace at five locations (middle), and survival rates by tailrace release location (bottom). Gray bars are for yearling Chinook salmon smolts; blue bars are for juvenile steelhead; vertical bars are $95 \%$ confidence intervals on survival estimates.

\subsubsection{Examination of Time In-river on Survivals of Different Release Groups}

The virtual release formed from the detections of upriver releases at the face of the dam could result in biased survival estimates if fish from varying upriver release locations had differential downriver survival rates. For this reason, reach survivals and cumulative survivals were compared across fish from different upriver release locations. There was no consistent or reproducible evidence to suggest that the amount of time (i.e., distance) in-river had a subsequent effect on downriver smolt survival for either yearling Chinook salmon or steelhead (Appendix A). Therefore, in constructing the virtual releases at the face of the dam, fish from all available upriver release locations were used in subsequent survival and other parameter estimation. Nevertheless, in the case of the John Day Dam compliance studies, only one upstream release location was available in forming the virtual-release group at the face of the dam (Figure 2.1).

\subsubsection{Fish Size Distributions}

Comparison of JSATS-tagged fish with ROR fish sampled at John Day Dam through the Smolt Monitoring Program shows that the length frequency distributions were generally well matched for yearling Chinook salmon (Figure 3.3) and steelhead (Figure 3.4). The length distributions for the three yearling Chinook salmon releases (Figure 3.5) and the three steelhead releases (Figure 3.5) were quite similar. Mean lengths for the acoustic-tagged yearling Chinook salmon were $148.6 \mathrm{~mm}$ and for the steelhead, $203.8 \mathrm{~mm}$. Mean lengths for yearling Chinook salmon and steelhead sampled by the Fish Passage Center at the John Day Dam juvenile sampling facility were $151.4 \mathrm{~mm}$ and $199.1 \mathrm{~mm}$, respectively. Fish size did not change over the course of the study (Figure 3.5). 
a. John Day Dam (Release $\left.V_{1}\right)$

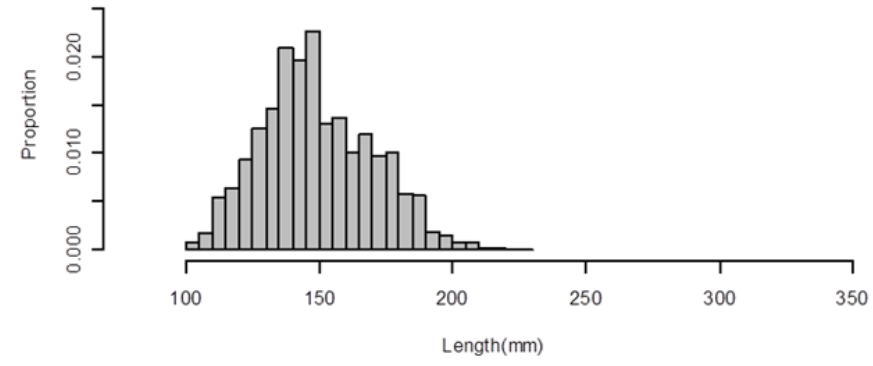

b. John Day Tailrace (Release $R_{2}$ )

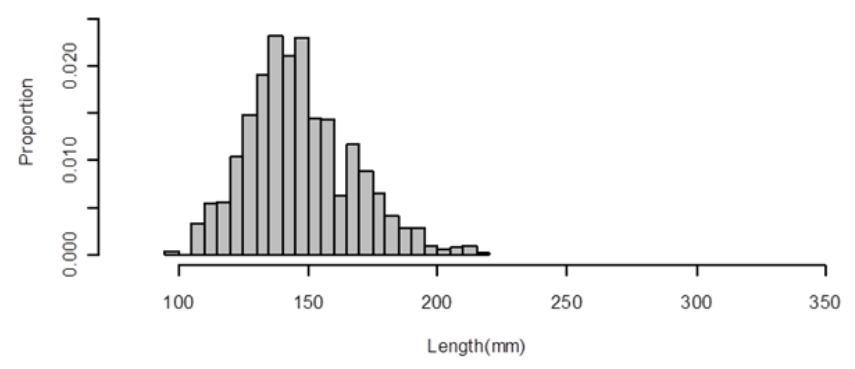

c. Mid-Reservoir (Release $R_{3}$ )
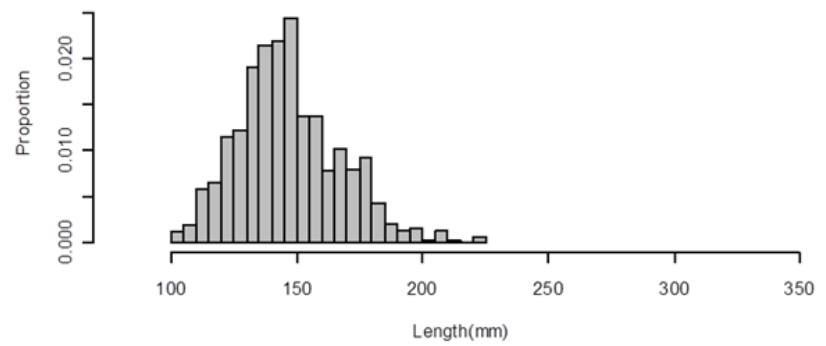

d. ROR Yearling Chinook at John Day Dam

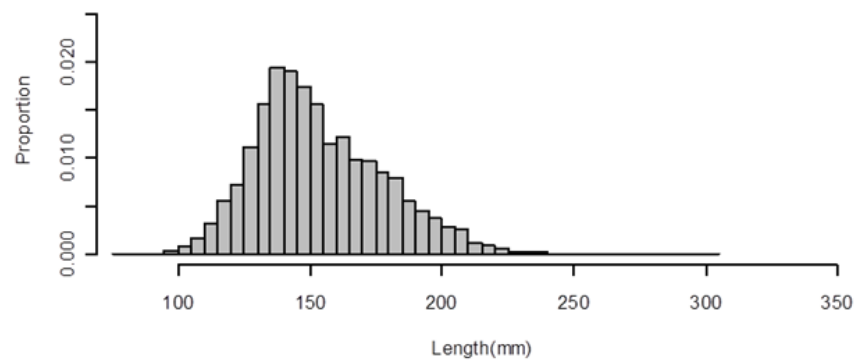

Figure 3.3. Relative frequency distributions for fish lengths $(\mathrm{mm})$ of yearling Chinook salmon smolts used in (a) release $V_{1}$, (b) release $R_{2}$, (c) release $R_{3}$, and (d) ROR fish sampled at John Day Dam by the Fish Passage Center. 
a. John Day Dam (Release $\left.V_{1}\right)$

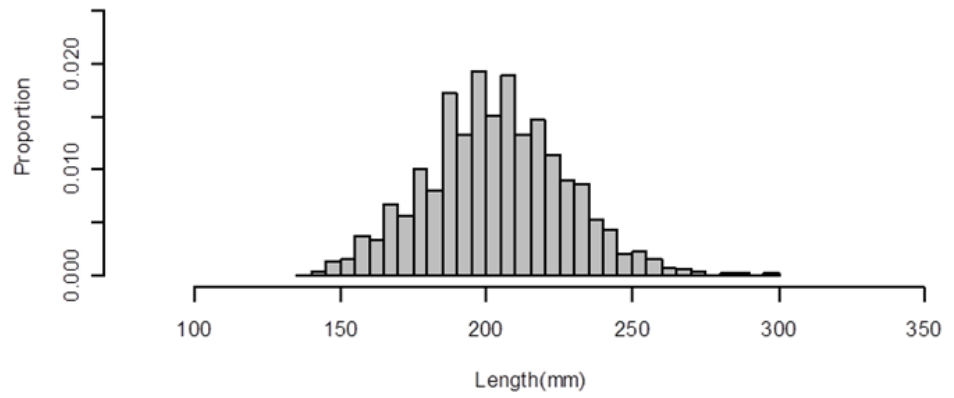

b. John Day Tailrace (Release $R_{2}$ )
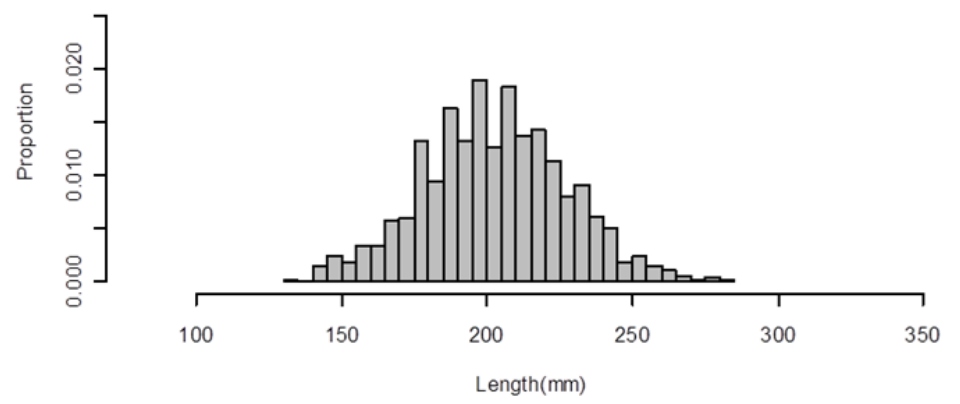

c. Mid-Reservoir (Release $R_{3}$ )

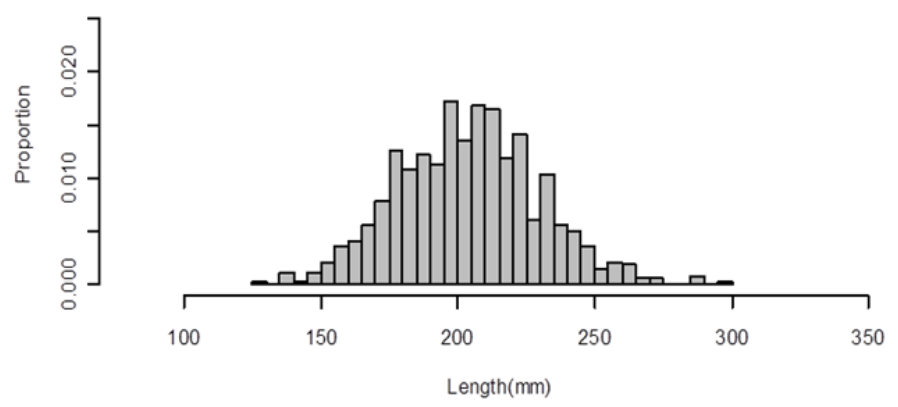

d. ROR Steelhead at John Day Dam

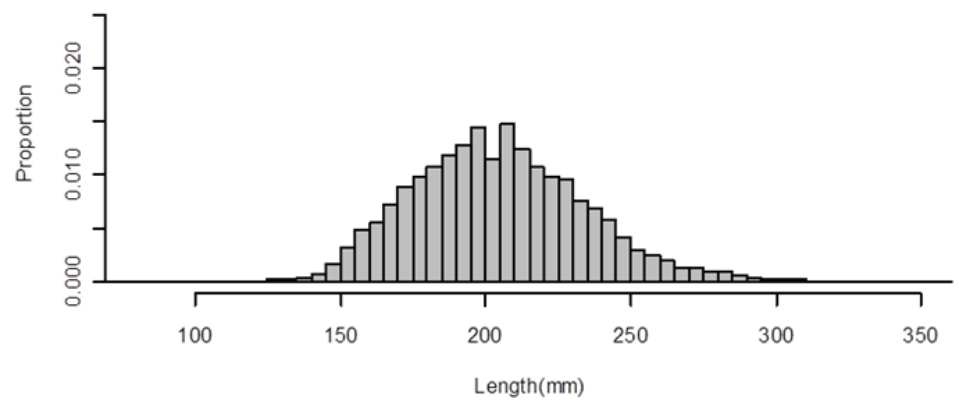

Figure 3.4. Relative frequency distributions for fish lengths ( $\mathrm{mm}$ ) of steelhead smolts used in (a) release $V_{1}$, (b) release $R_{2}$, (c) release $R_{3}$, and (d) ROR fish sampled at John Day Dam by the Fish Passage Center. 
a. Yearling Chinook salmon smolts

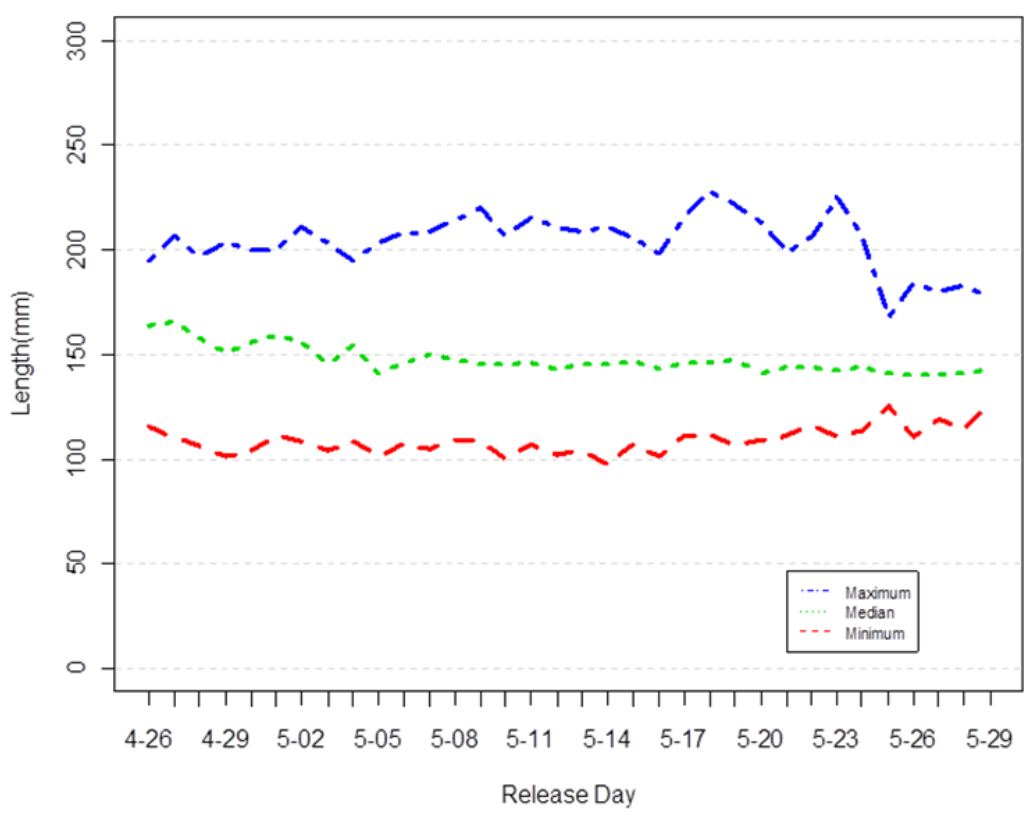

b. Steelhead smolts

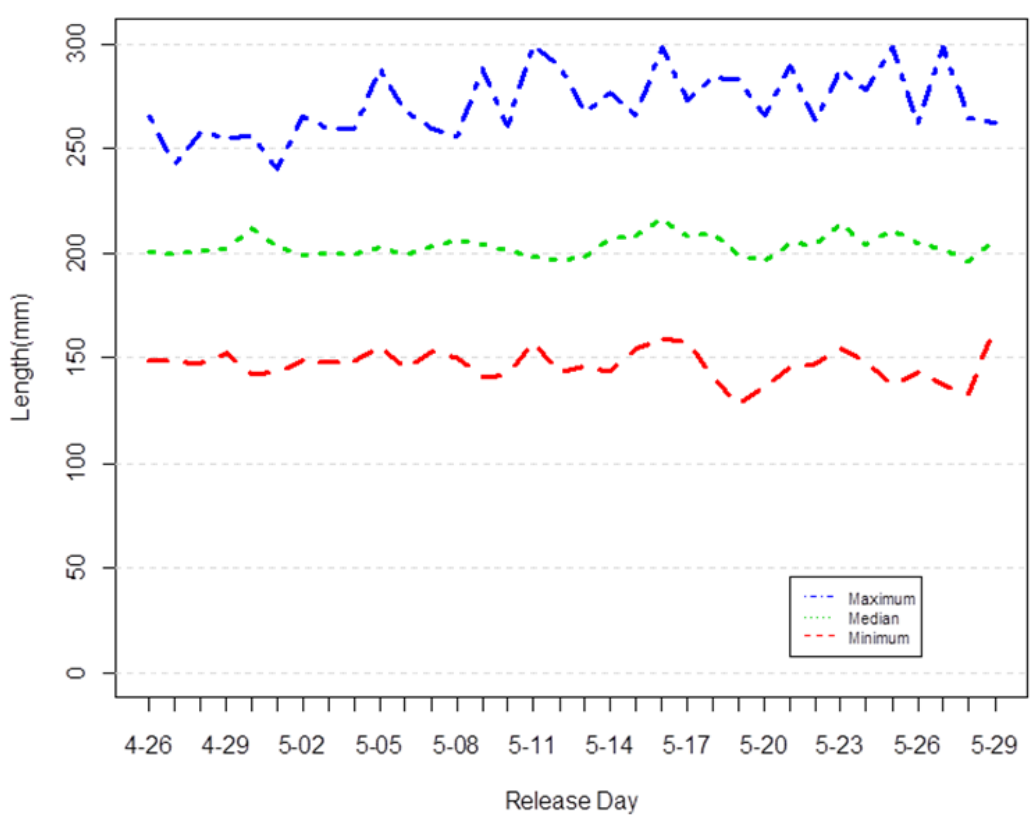

Figure 3.5. Range and median lengths of acoustically tagged (a) yearling Chinook salmon and (b) steelhead used in the 2011 survival studies. Releases were made daily from 27 April through 29 May at three release locations: rkm 390, rkm 346, and rkm 325. 


\subsubsection{Tag-Life Corrections}

During the 2011 spring study, five different manufacturing lots of JSATS tags were used in tagging the yearling Chinook salmon and steelhead smolts. Lot 1 was manufactured distinctly from lot 2, which was manufactured distinctly from lots 3-5. From each of these three groupings of tag lots, 50 to 59 tags were systematically sampled to conduct independent tag-life studies. Vitality curves of Li and Anderson (2009) were fit independently to each of the lots 1, 2, and 3-5 (Figure 3.6). Mantel-Haenszel (1959) tests of homogeneous tag-life distributions found lot 1 was significantly different from lot $2(P=0.0005)$ and lots 3-5 $(P=0.0023)$, but lots 2 and lots $3-5$ were not different $(P=0.5698)$ (Figure 3.7). Average tag lives were $31.74,30.32$, and 30.52 days for lots 1,2 , and $3-5$, respectively.

\subsubsection{Arrival Distributions}

The estimated probability an acoustic tag was active when fish arrived at a downstream detection array depends on the tag-life curve and the distribution of observed travel times (Figure 3.8).

Examination of the fish arrival distributions to the last detection array used in the survival analyses indicated all fish that arrived had passed through the study area before tag failure became important. These probabilities were calculated by integrating the tag survivorship curve (Figure 3.6, Figure 3.7) over the observed distribution of fish arrival times (i.e., time from tag activation to arrival). The three separate tag-life survivorship models for tag lots 1,2, and 3-5 were used to estimate the probabilities of tag failure and provide tag-life-adjusted estimates of smolt survival. The probabilities of a JSATS tag being active at a downstream detection site were specific to release location, tag lot, and species (Table 3.1). In all cases, the probability a tag was active at a downstream detection site as far as rkm 113 for yearling Chinook salmon smolts was $\geq 0.9929$ and $\geq 0.9937$ for steelhead smolts (Table 3.1).

\subsubsection{Downstream Mixing}

To help induce downstream mixing of the release groups, the $R_{1}$ release was $39 \mathrm{~h}$ before the $R_{2}$ release which, in turn, occurred $9 \mathrm{~h}$ before the $R_{3}$ release. The release schedule was used for both the yearling Chinook salmon and steelhead smolts. Plots of the arrival timing of the various release groups at downstream detection sites indicate reasonable mixing for both yearling Chinook salmon (Figure 3.9) and steelhead (Figure 3.10) smolts. The arrival modes for releases $R_{2}$ and $R_{3}$ were nearly synchronous. The modes for $R_{2}$ and $R_{3}$ were slightly later than the arrival mode for $V_{1}$ but during the majority of the distribution of arrival times for $V_{1}$ (Figure 3.9, Figure 3.10). 
(a) Tag lot 1

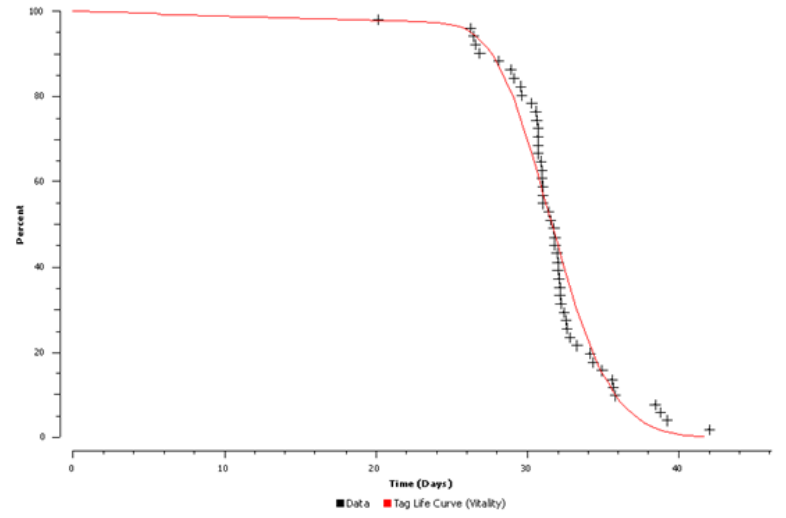

(c) Tag lot 3-5

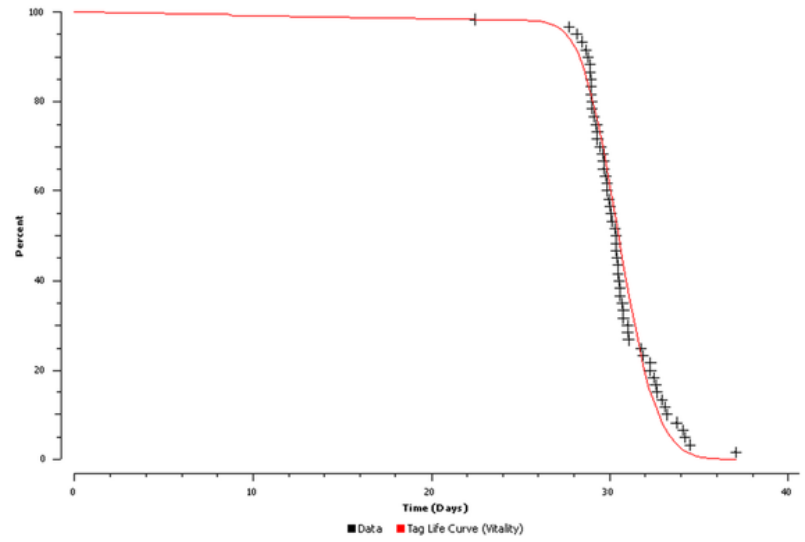

(b) Tag lot 2

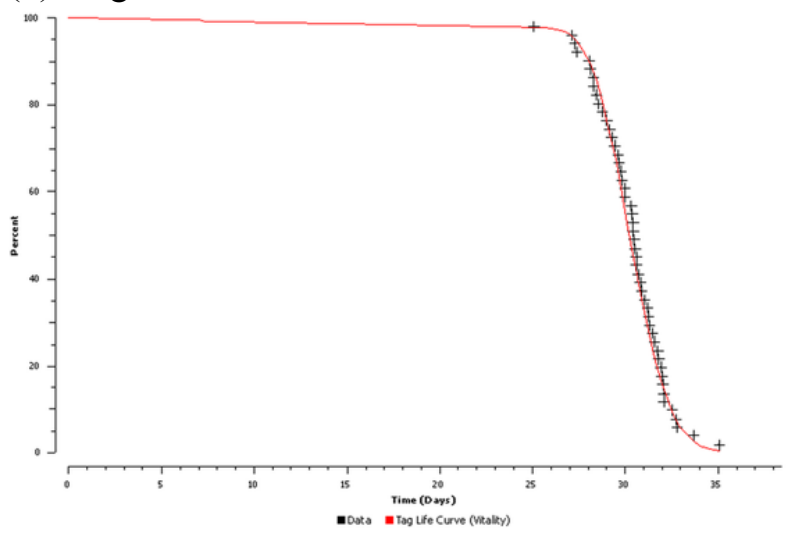

Figure 3.6. Observed time of tag failure and fitted survivorship curves using the vitality model of Li and Anderson (2009) for (a) tag lot 1, (b) tag lot 2, and (c) tag lots 3-5.

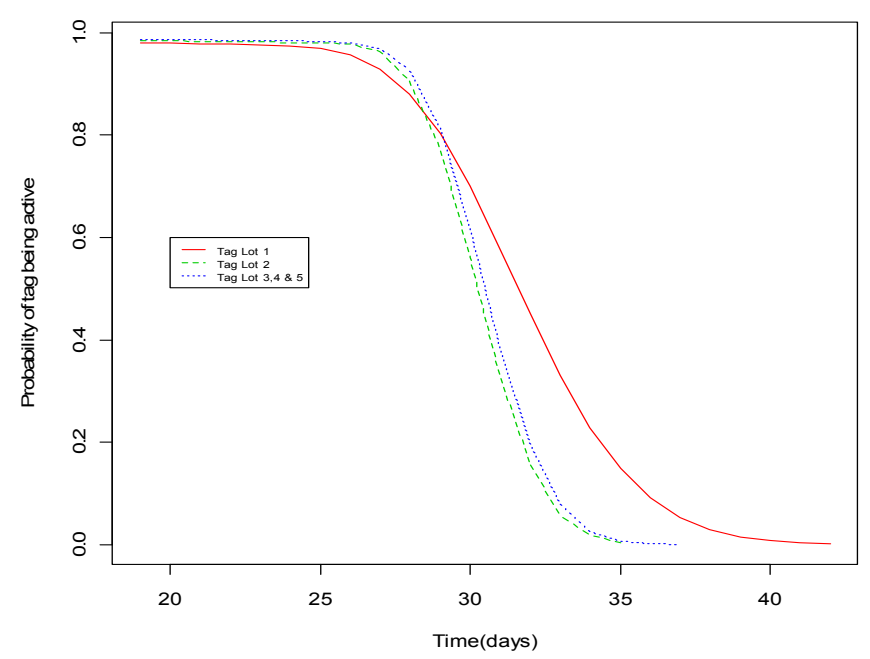

Figure 3.7. Comparison of fitted survivorship curves using the vitality model of Li and Anderson (2009) for JSATS tag lots 1, 2, and 3-5 used in the 2011 compliance studies. 
a. Yearling Chinook salmon

Tag lot 1

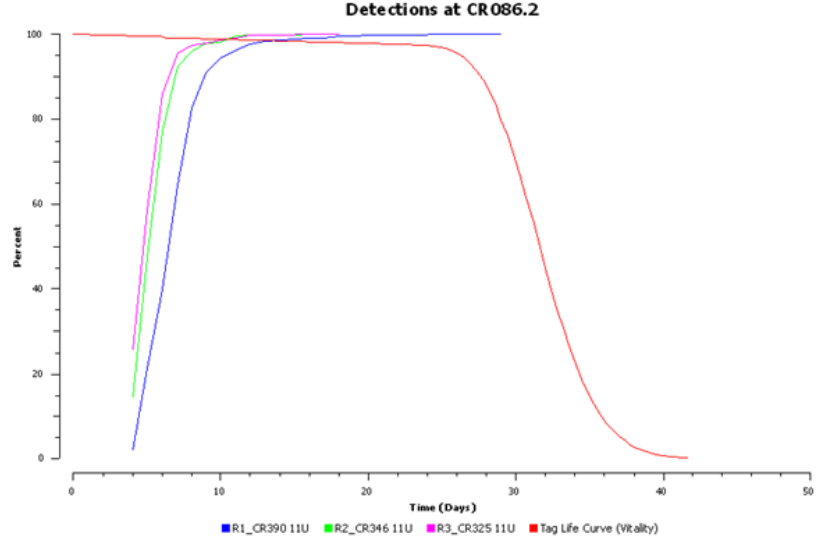

Tag lot 2

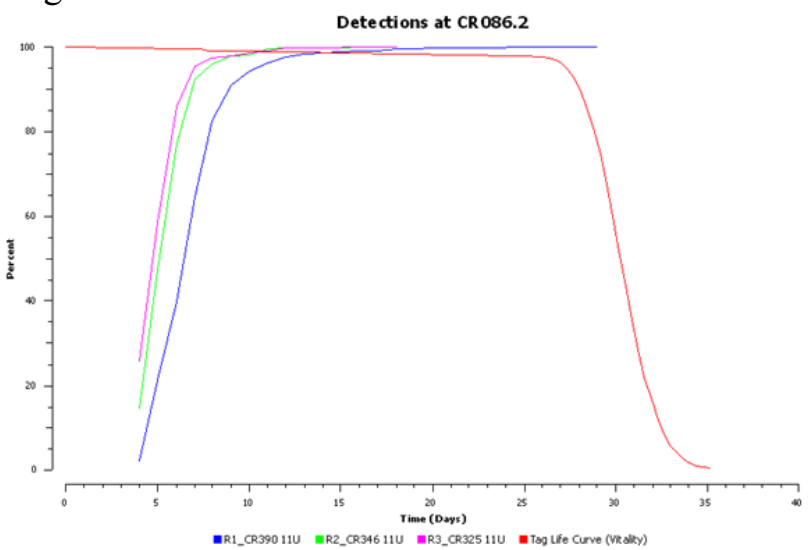

Tag lot 3-5

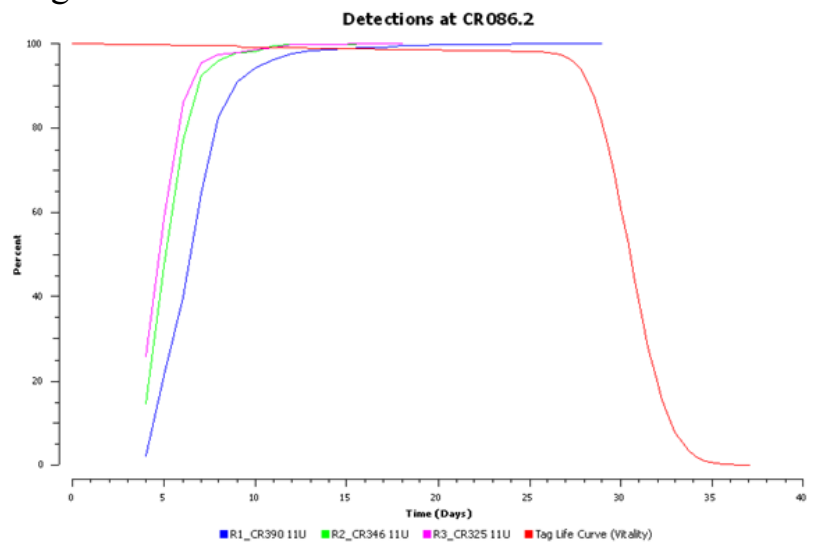

Figure 3.8. Plots of the fitted tag-life survivorship curve and the arrival-time distributions of (a) Yearling Chinook salmon smolts and (b) steelhead smolts for releases $V_{1}, R_{2}$, and $R_{3}$ at the acousticdetection array located at rkm 86.0 (Figure 2.1). 
b. Steelhead

Tag lot 1

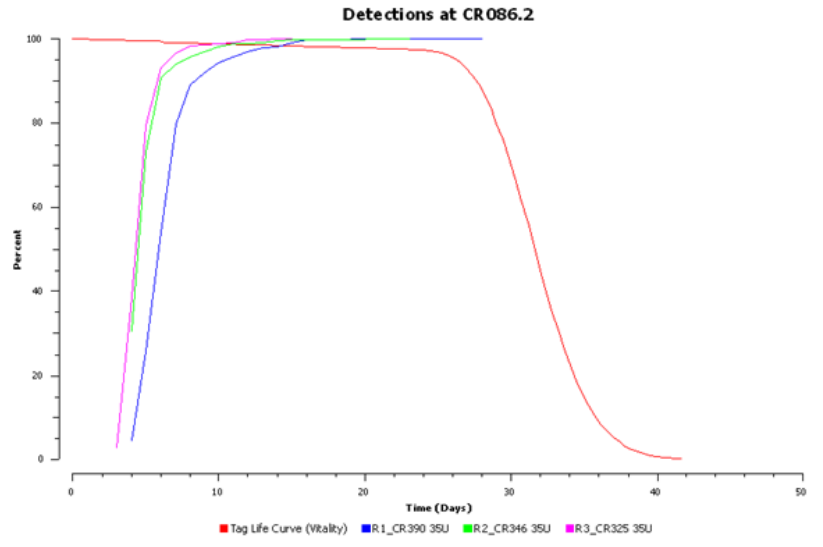

Tag lot 3-5

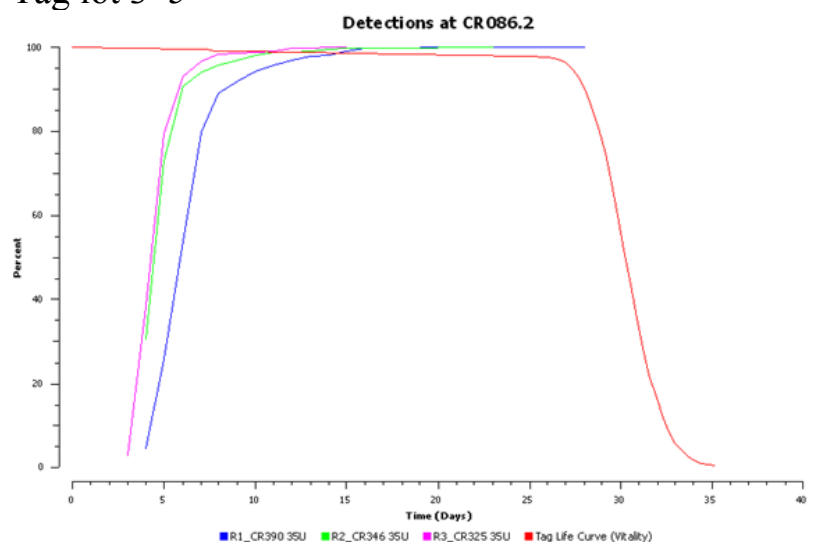

Tag lot 2

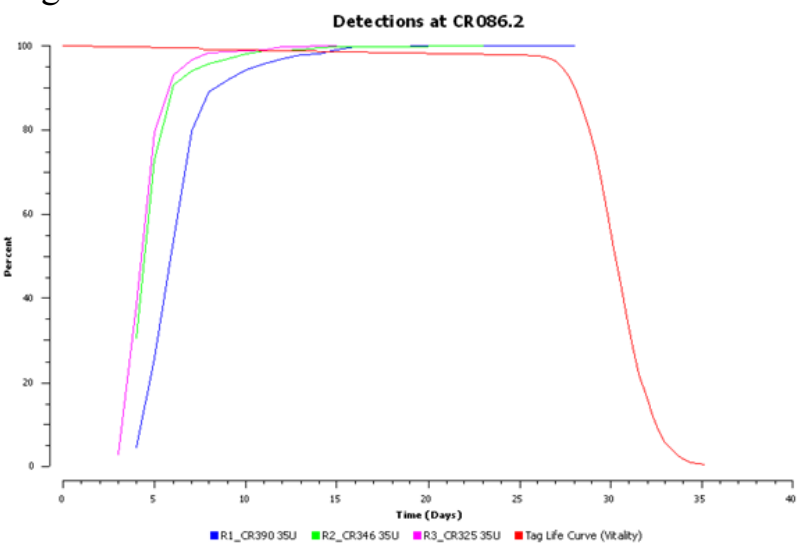

Figure 3.8. (contd) 
Table 3.1. Estimated probabilities $(L)$ of an acoustic tag being active at a downstream detection site for (a) yearling Chinook salmon smolts and (b) steelhead smolts by tag lot and release group. (Standard errors are in parentheses.)

\begin{tabular}{|c|c|c|c|c|c|c|c|}
\hline \multirow[t]{2}{*}{ Release Group } & \multirow[t]{2}{*}{ Tag Lot } & \multicolumn{6}{|l|}{ Detection Site } \\
\hline & & Rkm 325 & Rkm 309 & $\mathrm{Rkm} 275$ & Rkm 234 & Rkm 161 & Rkm 113 \\
\hline \multicolumn{8}{|c|}{ a. Yearling Chinook Salmon } \\
\hline \multirow[t]{3}{*}{$\begin{array}{l}V_{1}(\mathrm{Rkm} \\
349)^{(\mathrm{a})}\end{array}$} & 1 & $0.9994(0.0004)$ & $0.9990(0.0007)$ & $0.9984(0.0012)$ & $0.9975(0.0017)$ & $0.9960(0.0027)$ & $0.9953(0.0032)$ \\
\hline & 2 & $0.9996(0.0003)$ & $0.9993(0.0005)$ & $0.9988(0.0008)$ & $0.9982(0.0012)$ & $0.9974(0.0018)$ & $0.9969(0.0021)$ \\
\hline & $3-5$ & $0.9998(0.0006)$ & $0.9996(0.0010)$ & $0.9993(0.0020)$ & $0.9989(0.0032)$ & $0.9985(0.0049)$ & $0.9981(0.0060)$ \\
\hline \multirow[t]{3}{*}{$R_{2}(\mathrm{Rkm} 346)$} & 1 & -- & $0.9967(0.0024)$ & $0.9960(0.0029)$ & $0.9951(0.0035)$ & $0.9934(0.0047)$ & $0.9929(0.0053)$ \\
\hline & 2 & -- & $0.9974(0.0017)$ & $0.9969(0.0021)$ & $0.9962(0.0025)$ & $0.9953(0.0031)$ & $0.9948(0.0035)$ \\
\hline & $3-5$ & -- & $0.9981(0.0054)$ & $0.9978(0.0066)$ & $0.9972(0.0079)$ & $0.9968(0.0096)$ & $0.9965(0.0107)$ \\
\hline \multirow[t]{3}{*}{$R_{3}(\mathrm{Rkm} \mathrm{325)}$} & 1 & -- & $0.9972(0.0020)$ & $0.9964(0.0026)$ & $0.9955(0.0032)$ & $0.9942(0.0042)$ & $0.9935(0.0048)$ \\
\hline & 2 & -- & $0.9978(0.0014)$ & $0.9972(0.0018)$ & $0.9966(0.0022)$ & $0.9956(0.0029)$ & $0.9952(0.0033)$ \\
\hline & $3-5$ & -- & $0.9983(0.0048)$ & $0.9980(0.0060)$ & $0.9974(0.0072)$ & $0.9971(0.0088)$ & $0.9968(0.0099)$ \\
\hline \multicolumn{8}{|l|}{ b. Steelhead } \\
\hline \multirow[t]{3}{*}{$\begin{array}{l}V_{1}(\mathrm{Rkm} \\
349)^{(\mathrm{a})}\end{array}$} & 1 & $0.9988(0.0009)$ & $0.9986(0.0012)$ & $0.9980(0.0016)$ & $0.9973(0.0022)$ & $0.9961(0.0032)$ & $0.9959(0.0035)$ \\
\hline & 2 & $0.9994(0.0006)$ & $0.9992(0.0008)$ & $0.9987(0.0012)$ & $0.9983(0.0016)$ & $0.9975(0.0024)$ & $0.9971(0.0029)$ \\
\hline & $3-5$ & $0.9997(0.0011)$ & $0.9996(0.0015)$ & $0.9988(0.0026)$ & $0.9984(0.0038)$ & $0.9978(0.0053)$ & $0.9981(0.0063)$ \\
\hline \multirow[t]{3}{*}{$R_{2}(\mathrm{Rkm} 346)$} & 1 & -- & $0.9970(0.0026)$ & $0.9963(0.0032)$ & $0.9957(0.0037)$ & $0.9943(0.0049)$ & $0.9937(0.0054)$ \\
\hline & 2 & -- & $0.9976(0.0023)$ & $0.9970(0.0029)$ & $0.9965(0.0033)$ & $0.9957(0.0041)$ & $0.9953(0.0047)$ \\
\hline & $3-5$ & -- & $0.9981(0.0064)$ & $0.9979(0.0073)$ & $0.9974(0.0089)$ & $0.9970(0.0100)$ & $0.9967(0.0111)$ \\
\hline \multirow[t]{3}{*}{$R_{3}(\mathrm{Rkm} 325)$} & 1 & -- & $0.9974(0.0023)$ & $0.9967(0.0028)$ & $0.9961(0.0034)$ & $0.9947(0.0045)$ & $0.9942(0.0051)$ \\
\hline & 2 & -- & $0.9979(0.0021)$ & $0.9974(0.0025)$ & $0.9969(0.0030)$ & $0.9959(0.0040)$ & $0.9954(0.0045)$ \\
\hline & $3-5$ & -- & $0.9983(0.0058)$ & $0.9980(0.0067)$ & $0.9976(0.0081)$ & $0.9971(0.0097)$ & $0.9969(0.0105)$ \\
\hline
\end{tabular}

(a) Conditional probabilities of a tag being active, given they were active when a fish first arrived at the dam face. 
a. $\quad$ Rkm 309

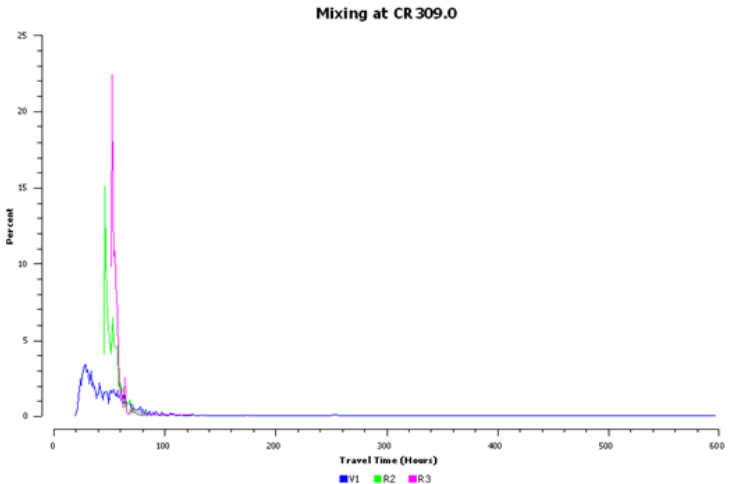

d. $\quad$ Rkm 161

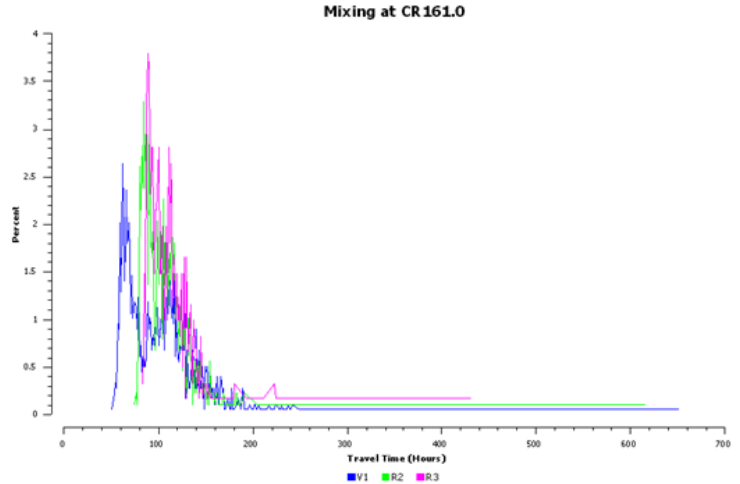

b. $\quad$ Rkm 275

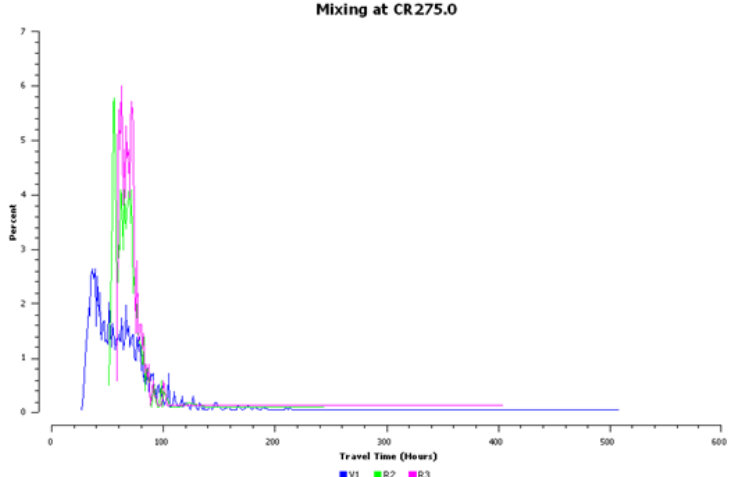

e. $R k m 113$

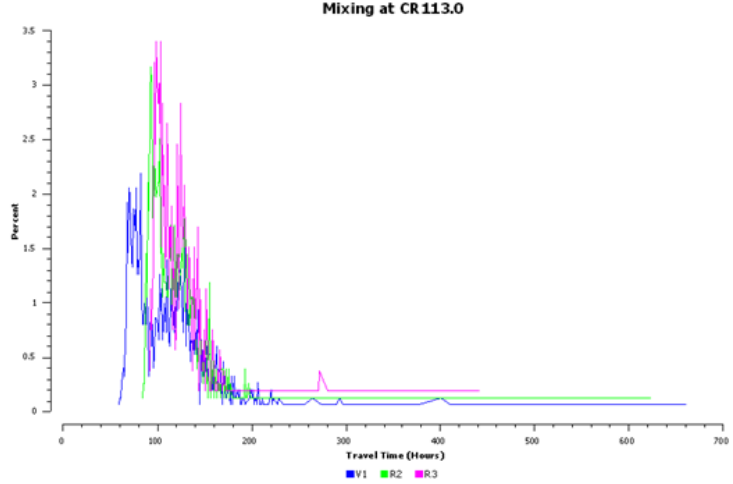

c. $\mathrm{Rkm} 234$

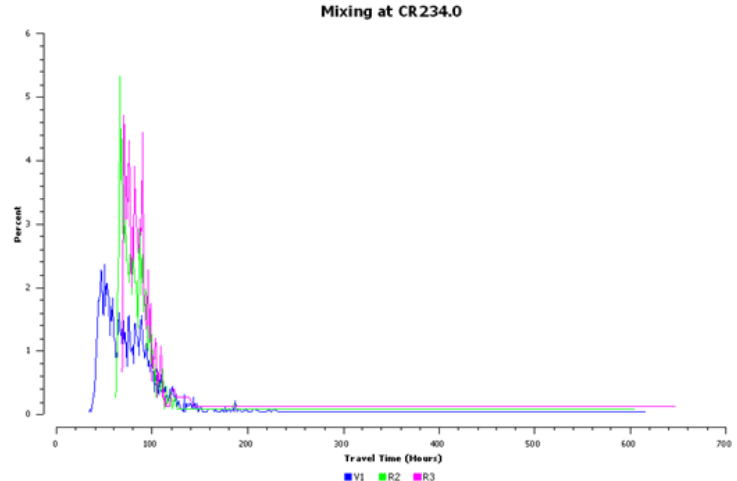

f. $\quad \mathrm{Rkm} 86$

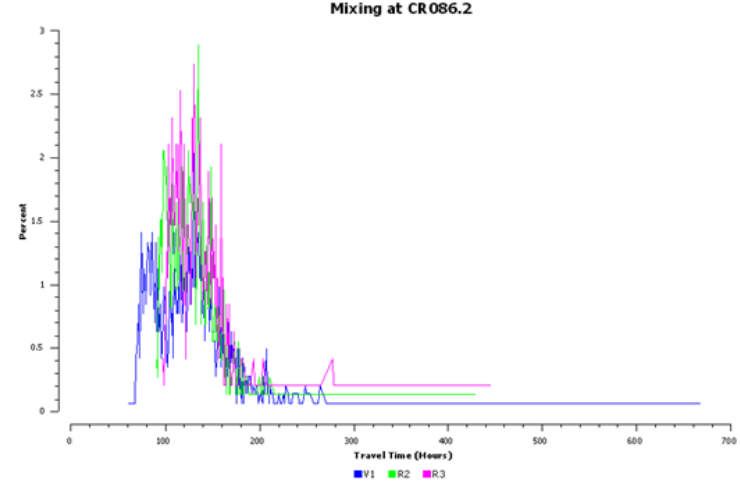

Figure 3.9. Frequency distribution plots of downstream arrival timing (expressed as percentages) for yearling Chinook salmon releases $V_{1}, R_{2}$, and $R_{3}$ at detection arrays located at (a) rkm 309, (b) rkm 275, (c) rkm 234, (d) rkm 161, (e) rkm 113, and (f) rkm 86. (See Figure 2.1.) All times adjusted relative to the release time of $V_{1}$. 
a. $\mathrm{Rkm} 309$

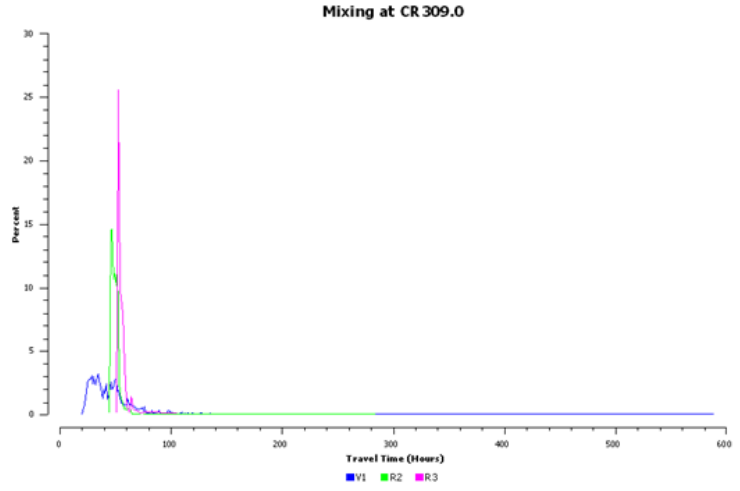

d. Rkm 161

$\stackrel{\omega}{\omega}$

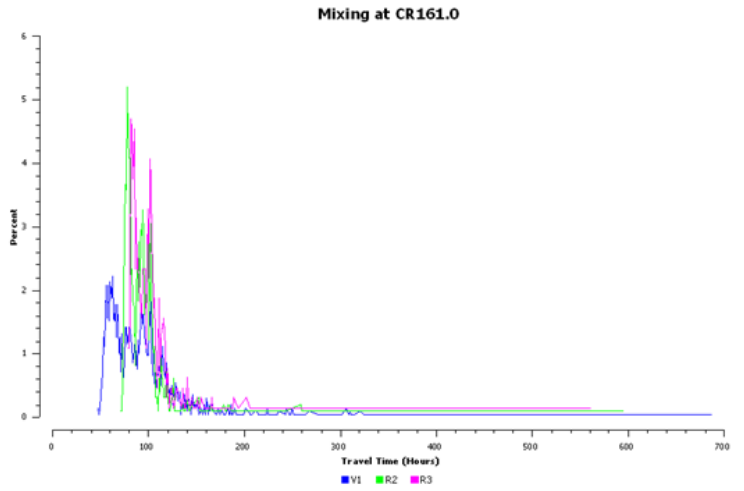

b. $\quad$ Rkm 275

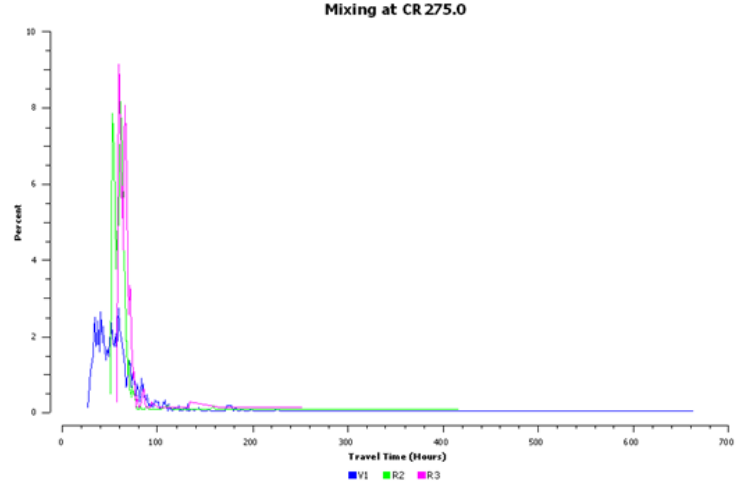

e. $\mathrm{Rkm} 113$

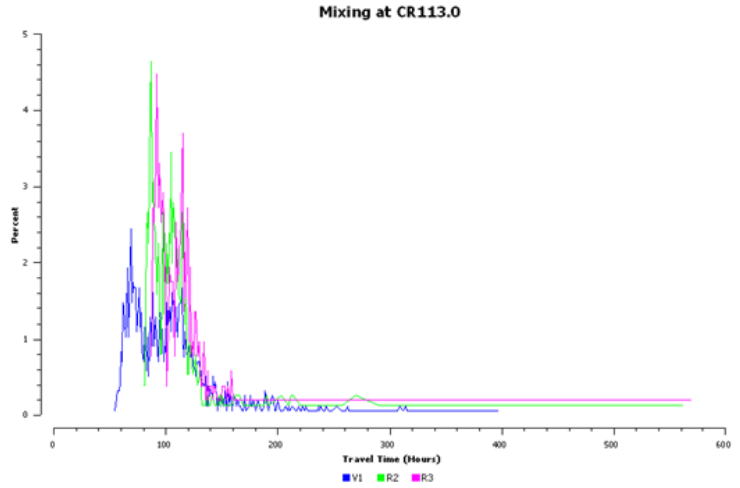

c. $\quad \mathrm{Rkm} 234$

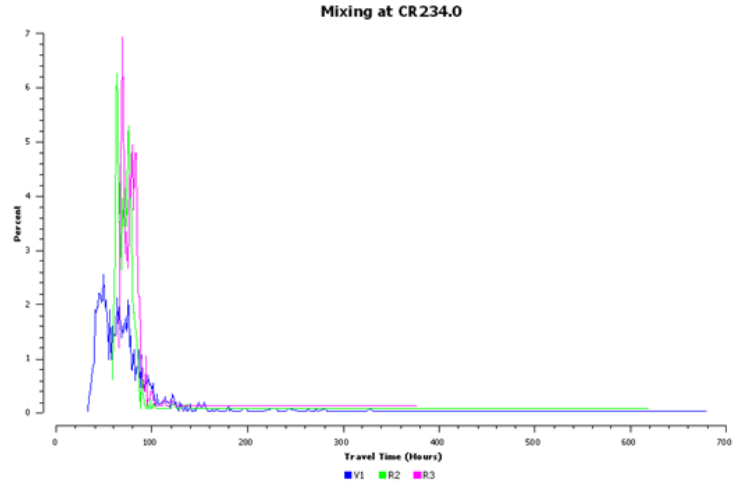

f. $\quad$ Rkm 86

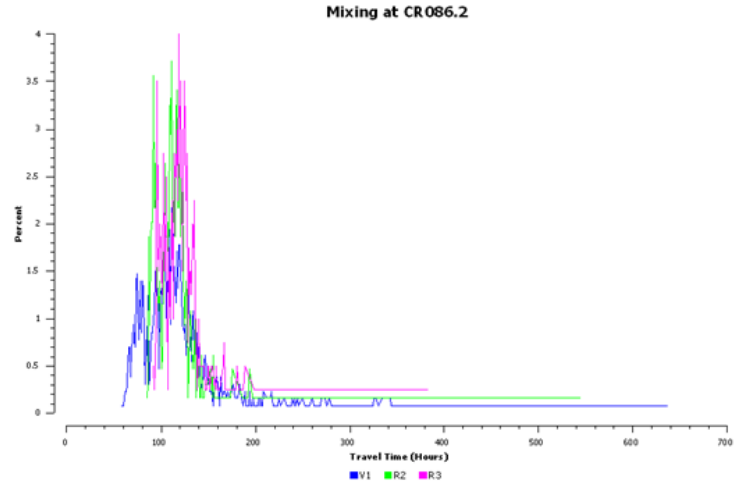

Figure 3.10. Frequency distribution plots of downstream arrival timing (expressed as percentages) for steelhead releases $V_{1}, R_{2}$, and $R_{3}$ at detection arrays located at (a) rkm 309, (b) rkm 275, (c) rkm 234, (d) rkm 161, (e) rkm 113, and (f) rkm 86. (See Figure 2.1.) All times adjusted relative to the release time of $V_{1}$. 


\subsection{Survival and Passage Performance}

Survival and passage performance metrics include dam passage survival, forebay-to-tailrace passage survival, forebay residence time, tailrace to egress time, SPE, and FPE.

\subsubsection{Dam Passage Survival}

The high river flows in 2011 interrupted the alternating 2-day blocks of either 30\% or $40 \%$ spill beginning on 18 April 2011. A post-facto analysis was therefore performed during four different time periods of the 2011 spring survival study:

- 30\% spill, early season (27 April - 16 May 2011)

- 40\% spill, early season (27 April - 16 May 2011)

- Late season (16 May - 29 May 2011)

- Season-wide (27 April - 29 May 2011).

Spill conditions were changed at 8 p.m.; consequently, a transition period from 7 to 9 p.m. was omitted from the analysis each time there was a shift in spill conditions. The smolts forming the virtual releases at the dam face were based on this schedule. The entire set of below-dam paired releases $R_{2}$ and $R_{3}$ for the early period were used in estimating dam passage survival for both the $30 \%$ and $40 \%$ spill conditions during the early season. The virtual releases $\left(V_{1}\right)$ for the $30 \%$ and $40 \%$ spill blocks were pooled across blocks when estimating dam passage survival.

\subsubsection{Yearling Chinook Salmon}

For the early period (i.e., 27 April -16 May 2011), a total of $V_{1}=931$ yearling Chinook salmon smolts formed the virtual release for the $30 \%$ spill condition. Dam passage survival was then estimated to be

$$
\hat{S}_{\text {Dam }}=\frac{0.9532}{\left(\frac{0.9776}{0.9914}\right)}=\frac{0.9532}{0.9861}=0.9666
$$

with an associated standard error of $\widehat{\mathrm{SE}}=0.0103$ (Table 3.2). For the early period, a total of $V_{1}=$ 618 yearling Chinook salmon smolts formed the virtual release for the $40 \%$ spill condition. Dam passage survival was then estimated to be

$$
\hat{S}_{\text {Dam }}=\frac{0.9649}{\left(\frac{0.9776}{0.9914}\right)}=\frac{0.9649}{0.9861}=0.9784
$$

with an associated standard error of $\widehat{\mathrm{SE}}=0.0107$ (Table 3.3). 
Table 3.2. Survival, detection, and $\lambda$ parameters for final model used to estimate dam passage survival for yearling Chinook salmon during the early part of the spring study for 30\% spill conditions (27 April - 16 May 2011). Standard errors (SE) based on both the inverse hessian matrix and bootstrapping for key parameters $(\dagger)$ and only the inverse hessian matrix for associated parameters $(*)$.

\begin{tabular}{|c|c|c|c|c|c|c|c|c|c|c|c|c|}
\hline \multirow[b]{2}{*}{ Release } & \multicolumn{2}{|c|}{ CR349 to 325} & \multicolumn{2}{|c|}{ CR325 to 309} & \multicolumn{2}{|c|}{ Release to CR309 } & \multicolumn{2}{|c|}{ CR309 to 275} & \multicolumn{2}{|c|}{ CR275 to 234} & \multicolumn{2}{|c|}{ CR234 to 161} \\
\hline & $\hat{S}$ & $\widehat{\mathrm{SE}}^{\dagger}$ & $\hat{S}$ & $\widehat{\mathrm{SE}}^{*}$ & $\hat{S}$ & $\widehat{\mathrm{SE}}^{\dagger}$ & $\hat{S}$ & $\widehat{\mathrm{SE}}^{*}$ & $\hat{S}$ & $\widehat{\mathrm{SE}}^{*}$ & $\hat{S}$ & $\widehat{\mathrm{SE}}^{*}$ \\
\hline$R_{1}$ & 0.9532 & 0.0070 & 0.9890 & 0.0035 & --- & --- & 0.9628 & 0.0064 & 0.9971 & 0.0021 & 0.9603 & 0.0079 \\
\hline$R_{2}$ & --- & --- & --- & --- & 0.9776 & 0.0059 & 0.9476 & 0.0085 & 0.9930 & 0.0034 & 0.9516 & 0.0089 \\
\hline$R_{3}$ & --- & --- & --- & --- & 0.9914 & 0.0050 & 0.9578 & 0.0096 & 0.9864 & 0.0058 & 0.9548 & 0.0108 \\
\hline
\end{tabular}

\begin{tabular}{|c|c|c|c|c|c|c|c|c|c|c|c|c|}
\hline \multirow[b]{2}{*}{ Release } & \multicolumn{2}{|c|}{ CR161 to 113} & \multicolumn{2}{|c|}{ CR325 } & \multicolumn{2}{|c|}{ CR309 } & \multicolumn{2}{|c|}{ CR275 } & \multicolumn{2}{|c|}{ CR 234} & \multicolumn{2}{|c|}{ CR161 } \\
\hline & $\hat{S}$ & $\widehat{\mathrm{SE}}^{*}$ & $\hat{p}$ & $\widehat{\mathrm{SE}}^{*}$ & $\hat{p}$ & $\widehat{\mathrm{SE}}^{*}$ & $\hat{p}$ & $\widehat{\mathrm{SE}}^{*}$ & $\hat{p}$ & $\widehat{\mathrm{SE}}^{*}$ & $\hat{p}$ & $\widehat{\mathrm{SE}}^{*}$ \\
\hline$R_{1}$ & 0.9945 & 0.0127 & 1.0000 & 0.0000 & 0.9988 & 0.0012 & 0.9845 & 0.0043 & 1.0000 & 0.0000 & 0.8575 & 0.0130 \\
\hline$R_{2}$ & 0.9912 & 0.0096 & --- & --- & 0.9985 & 0.0015 & 0.9939 & 0.0030 & 1.0000 & 0.0000 & 0.8848 & 0.0130 \\
\hline$R_{3}$ & 0.9849 & 0.0116 & --- & --- & 0.9976 & 0.0024 & 0.9928 & 0.0041 & 1.0000 & 0.0000 & 0.8932 & 0.0158 \\
\hline
\end{tabular}

\begin{tabular}{ccccc}
\hline & \multicolumn{2}{c}{ CR113 } & \multicolumn{2}{c}{ CR113-86 } \\
\cline { 2 - 5 } Release & $\hat{S}$ & $\widehat{\mathrm{SE}}^{*}$ & $\hat{\lambda}$ & $\widehat{\mathrm{SE}}^{*}$ \\
\hline$R_{1}$ & 0.7145 & 0.0183 & 0.7874 & 0.0175 \\
$R_{2}$ & 0.7780 & 0.0180 & 0.8689 & 0.0154 \\
$R_{3}$ & 0.8006 & 0.0215 & 0.8796 & 0.0184 \\
\hline
\end{tabular}


Table 3.3. Survival, detection, and $\lambda$ parameters for final model used to estimate dam passage survival for yearling Chinook salmon during the early part of the spring study for $40 \%$ spill conditions (27 April - 16 May 2011). Standard errors (SE) based on both the inverse hessian matrix and bootstrapping for key parameters $(\dagger)$ and only the inverse hessian matrix for associated parameters $(*)$.

\begin{tabular}{ccccccccccccc} 
& \multicolumn{2}{c}{ CR349 to 325} & \multicolumn{2}{c}{ CR325 to 309} & \multicolumn{2}{c}{ Release to CR309 } & \multicolumn{2}{c}{ CR309 to 275 } & \multicolumn{3}{c}{ CR275 to 234 } & \multicolumn{2}{c}{ CR234 to 161 } \\
Release & $\hat{S}$ & $\widehat{\mathrm{SE}}^{\dagger}$ & $\hat{S}$ & $\widehat{\mathrm{SE}}^{*}$ & $\hat{S}$ & $\widehat{\mathrm{SE}}^{\dagger}$ & $\hat{S}$ & $\widehat{\mathrm{SE}}^{*}$ & $\hat{S}$ & $\widehat{\mathrm{SE}}^{*}$ & $\hat{S}^{*}$ & $\widehat{\mathrm{SE}}^{*}$ \\
\hline$R_{1}$ & 0.9649 & 0.0075 & 0.9937 & 0.0033 & --- & --- & 0.9617 & 0.0079 & 0.9954 & 0.0030 & 0.9562 & 0.0090 \\
$R_{2}$ & --- & --- & --- & --- & 0.9776 & 0.0060 & 0.9476 & 0.0085 & 0.9930 & 0.0034 & 0.9516 & 0.0089 \\
$R_{3}$ & --- & --- & --- & --- & 0.9914 & 0.0050 & 0.9578 & 0.0096 & 0.9864 & 0.0058 & 0.9548 & 0.0108 \\
\hline
\end{tabular}

\begin{tabular}{|c|c|c|c|c|}
\hline \multirow[b]{2}{*}{ Release } & \multicolumn{2}{|c|}{ CR161 to 113} & \multicolumn{2}{|c|}{ CR325 } \\
\hline & $\hat{S}$ & $\widehat{\mathrm{SE}}^{*}$ & $\hat{p}$ & $\widehat{\mathrm{SE}}^{*}$ \\
\hline$R_{1}$ & 0.9979 & 0.0064 & 1.0000 & 0.0000 \\
\hline$R_{2}$ & 0.9912 & 0.0096 & --- & --- \\
\hline \multirow[t]{2}{*}{$R_{3}$} & 0.9849 & 0.0116 & --- & --- \\
\hline & \multicolumn{2}{|c|}{ CR113 } & \multicolumn{2}{|c|}{ CR113-86 } \\
\hline Release & $\hat{S}$ & $\widehat{\mathrm{SE}}^{*}$ & $\hat{\lambda}$ & $\widehat{\mathrm{SE}}^{*}$ \\
\hline$R_{1}$ & 0.8347 & 0.0170 & 0.9175 & 0.0132 \\
\hline$R_{2}$ & 0.7780 & 0.0180 & 0.8689 & 0.0154 \\
\hline$R_{3}$ & 0.8006 & 0.0215 & 0.8796 & 0.0184 \\
\hline
\end{tabular}


During the late season (16 April - 29 May), spill conditions were $\geq 40 \%$ for the entire period. A total of $V_{1}=860$ Chinook formed the virtual-release group for that part of the study and all below-dam releases after 9 p.m. on 16 May 2011 were used in forming the $R_{2}$ and $R_{3}$ release groups. In estimating dam passage survival for that period of time, the paired release below John Day Dam estimated survival from the tailrace to rkm 325 to be

$$
\hat{S}=\frac{0.9873}{0.9843}=1.0030
$$

Hence, survival through that reach was set to 1.0 and the virtual release $\left(V_{1}\right)$ from the face of the dam to $\mathrm{rkm} 325$ of $\hat{S}=0.9702$ ( $\widehat{\mathrm{SE}}=0.0058$ ) was used as a conservative estimate of dam passage survival (Table 3.4). For the entire spring study, dam passage survival for yearling Chinook salmon smolts was estimated to be

$$
\hat{S}_{\text {Dam }}=\frac{0.9620}{\left(\frac{0.9816}{0.9874}\right)}=\frac{0.9620}{0.9941}=0.9676
$$

with an associated standard error of $\widehat{\mathrm{SE}}=0.0071$ (Table 3.5).

In all of the above analyses, the full model that estimated unique survival and capture probabilities for each release group was used in the calculation of dam passage survival. Precision was more than adequate (i.e., $\widehat{\mathrm{SE}} \leq 0.015$ ), so there was no need to attempt to find a more parsimonious model to improve precision. In this way, both precision and robustness were preserved. 
Table 3.4. Survival, detection, and $\lambda$ parameters for the final model used to estimate dam passage survival for yearling Chinook salmon during the latter part of the spring study (16 - 29 May 2011). Standard errors (SE) based on both the inverse hessian matrix and bootstrapping for key parameters $(\dagger)$ and only the inverse hessian matrix for associated parameters $(*)$.

\begin{tabular}{|c|c|c|c|c|c|c|c|c|c|c|c|c|}
\hline \multirow[b]{2}{*}{ Release } & \multicolumn{2}{|c|}{ CR349 to 325} & \multicolumn{2}{|c|}{ CR325 to 309} & \multicolumn{2}{|c|}{ Release to CR309 } & \multicolumn{2}{|c|}{ CR309 to 275} & \multicolumn{2}{|c|}{ CR275 to 234} & \multicolumn{2}{|c|}{ CR234 to 161} \\
\hline & $\hat{S}$ & $\widehat{\mathrm{SE}}^{\dagger}$ & $\hat{S}$ & $\widehat{\mathrm{SE}}^{*}$ & $\hat{S}$ & $\widehat{\mathrm{SE}}^{\dagger}$ & $\hat{S}$ & $\widehat{\mathrm{SE}}^{*}$ & $\hat{S}$ & $\widehat{\mathrm{SE}}^{*}$ & $\hat{S}$ & $\widehat{\mathrm{SE}}^{*}$ \\
\hline$R_{1}$ & 0.9702 & 0.0058 & 0.9947 & 0.0028 & --- & --- & 0.9647 & 0.0067 & 0.9928 & 0.0034 & 0.9660 & 0.0151 \\
\hline$R_{2}$ & --- & --- & --- & --- & 0.9873 & 0.0086 & 0.9623 & 0.0090 & 0.9977 & 0.0029 & 0.9726 & 0.0217 \\
\hline$R_{3}$ & --- & --- & --- & --- & 0.9843 & 0.0095 & 0.9429 & 0.0132 & 1.0000 & 0.0000 & 0.9425 & 0.0209 \\
\hline
\end{tabular}

\begin{tabular}{|c|c|c|c|c|c|c|c|c|c|c|c|c|}
\hline \multirow[b]{2}{*}{ Release } & \multicolumn{2}{|c|}{ CR325 } & \multicolumn{2}{|c|}{ CR309 } & \multicolumn{2}{|c|}{ CR275 } & \multicolumn{2}{|c|}{ CR234 } & \multicolumn{2}{|c|}{ CR161 } & \multicolumn{2}{|c|}{ CR161-113 } \\
\hline & $\hat{p}$ & $\widehat{\mathrm{SE}}^{*}$ & $\hat{p}$ & $\widehat{\mathrm{SE}}^{*}$ & $\hat{p}$ & $\widehat{\mathrm{SE}}^{*}$ & $\hat{p}$ & $\widehat{\mathrm{SE}}^{*}$ & $\hat{p}$ & $\widehat{\mathrm{SE}}^{*}$ & $\hat{\lambda}$ & $\widehat{\mathrm{SE}}^{*}$ \\
\hline$R_{1}$ & 0.9554 & 0.0072 & 0.9762 & 0.0054 & 0.8098 & 0.0139 & 1.0000 & 0.0000 & 0.7802 & 0.0186 & 0.6495 & 0.0196 \\
\hline$R_{2}$ & --- & --- & 0.9933 & 0.0038 & 0.7661 & 0.0200 & 1.0000 & 0.0000 & 0.7536 & 0.0259 & 0.6324 & 0.0266 \\
\hline$R_{3}$ & --- & --- & 0.9801 & 0.0081 & 0.7873 & 0.0236 & 1.0000 & 0.0000 & 0.8392 & 0.0260 & 0.7019 & 0.0297 \\
\hline
\end{tabular}


Table 3.5. Survival, detection, and $\lambda$ parameters for the final model used to estimate dam passage survival for yearling Chinook salmon during the entire spring study (27 April - 29 May 2011). Standard errors (SE) based on both the inverse hessian matrix and bootstrapping for key parameters $(\dagger)$ and only the inverse hessian matrix for associated parameters $(*)$.

\begin{tabular}{|c|c|c|c|c|c|c|c|c|c|c|c|c|}
\hline \multirow[b]{2}{*}{ Release } & \multicolumn{2}{|c|}{ CR349 to 325} & \multicolumn{2}{|c|}{ CR325 to 309} & \multicolumn{2}{|c|}{ Release to CR309 } & \multicolumn{2}{|c|}{ CR309 to 275} & \multicolumn{2}{|c|}{ CR275 to 234} & \multicolumn{2}{|c|}{ CR234 to 161} \\
\hline & $\hat{S}$ & $\widehat{\mathrm{SE}}^{\dagger}$ & $\hat{S}$ & $\widehat{\mathrm{SE}}^{*}$ & $\hat{S}$ & $\widehat{\mathrm{SE}}^{\dagger}$ & $\hat{S}$ & $\widehat{\mathrm{SE}}^{*}$ & $\hat{S}$ & $\widehat{\mathrm{SE}}^{*}$ & $\hat{S}$ & $\widehat{\mathrm{SE}}^{*}$ \\
\hline$R_{1}$ & 0.9620 & 0.0039 & 0.9924 & 0.0019 & --- & --- & 0.9635 & 0.0039 & 0.9953 & 0.0016 & 0.9547 & 0.0054 \\
\hline$R_{2}$ & --- & --- & --- & --- & 0.9816 & 0.0044 & 0.9538 & 0.0062 & 0.9947 & 0.0024 & 0.9518 & 0.0080 \\
\hline$R_{3}$ & --- & --- & --- & --- & 0.9874 & 0.0047 & 0.9525 & 0.0077 & 0.9919 & 0.0036 & 0.9464 & 0.0095 \\
\hline
\end{tabular}

\begin{tabular}{|c|c|c|c|c|c|c|c|c|c|c|c|c|}
\hline \multirow[b]{2}{*}{ Release } & \multicolumn{2}{|c|}{ CR161 to 113} & \multicolumn{2}{|c|}{ CR325 } & \multicolumn{2}{|c|}{ CR309 } & \multicolumn{2}{|c|}{ CR275 } & \multicolumn{2}{|c|}{ CR 234} & \multicolumn{2}{|c|}{ CR161 } \\
\hline & $\hat{S}$ & $\widehat{\mathrm{SE}}^{*}$ & $\hat{p}$ & $\widehat{\mathrm{SE}}^{*}$ & $\hat{p}$ & $\widehat{\mathrm{SE}}^{*}$ & $\hat{p}$ & $\widehat{\mathrm{SE}}^{*}$ & $\hat{p}$ & $\widehat{\mathrm{SE}}^{*}$ & $\hat{p}$ & $\widehat{\mathrm{SE}}^{*}$ \\
\hline$R_{1}$ & 0.9581 & 0.0094 & 0.9841 & 0.0026 & 0.9911 & 0.0020 & 0.9260 & 0.0055 & 1.0000 & 0.0000 & 0.8571 & 0.0081 \\
\hline$R_{2}$ & 0.9515 & 0.0133 & --- & --- & 0.9964 & 0.0018 & 0.9015 & 0.0090 & 1.0000 & 0.0000 & 0.8380 & 0.0121 \\
\hline$R_{3}$ & 0.9799 & 0.0155 & --- & --- & 0.9907 & 0.0035 & 0.9098 & 0.0105 & 1.0000 & 0.0000 & 0.8623 & 0.0136 \\
\hline
\end{tabular}

\begin{tabular}{ccccc}
\hline & \multicolumn{2}{c}{ CR113 } & \multicolumn{2}{c}{ CR113-86 } \\
\cline { 2 - 5 } Release & $\hat{S}$ & $\widehat{\mathrm{SE}}^{*}$ & $\hat{\lambda}$ & $\widehat{\mathrm{SE}}^{*}$ \\
\hline$R_{1}$ & 0.7574 & 0.0114 & 0.7142 & 0.0117 \\
$R_{2}$ & 0.7569 & 0.0159 & 0.7249 & 0.0162 \\
$R_{3}$ & 0.7684 & 0.0194 & 0.6902 & 0.0201 \\
\hline
\end{tabular}




\subsubsection{Steelhead}

During the 30\% spill blocks in the early season (27 April - 16 May 2011), a total of $V_{1}=991$ fish formed the virtual-release group. Dam passage survival during that spill condition was then estimated to be

$$
\hat{S}_{\text {Dam }}=\frac{0.9682}{\left(\frac{0.9799}{0.9956}\right)}=\frac{0.9682}{0.9842}=0.9836
$$

with an associated standard error of $\widehat{\mathrm{SE}}=0.0090$ (Table 3.6). During the same period when $40 \%$ spill occurred, a total of $V_{1}=598$ steelhead smolts formed the virtual-release group, and dam passage was estimated to be

$$
\hat{S}_{\text {Dam }}=\frac{0.9742}{\left(\frac{0.9799}{0.9956}\right)}=\frac{0.9742}{0.9842}=0.9897
$$

with an associated standard error of $\widehat{\mathrm{SE}}=0.0096$ (Table 3.7).

For the latter half of the season (i.e., 18 - 29 May 2011), when spills were in excess of $40 \%$ for the entire period, dam passage survival was estimated to be

$$
\hat{S}_{\text {Dam }}=\frac{0.9857}{\left(\frac{0.9853}{0.9894}\right)}=\frac{0.9857}{0.9959}=0.9899
$$

with an associated standard error of $\widehat{\mathrm{SE}}=0.0094$ (Table 3.8). A total of $V_{1}=939$ steelhead formed the virtual-release group for the late season estimate of dam passage survival. Pooling the data across the entire spring study with a virtual-release group of $V_{1}=2469$, season-wide dam passage survival for steelhead was estimated at

$$
\hat{S}_{\text {Dam }}=\frac{0.9757}{\left(\frac{0.9821}{0.9932}\right)}=\frac{0.9757}{0.9888}=0.9867
$$

with an associated standard error of $\widehat{\mathrm{SE}}=0.0061$ (Table 3.9).

In all cases, the estimates of dam passage survival for steelhead at John Day Dam in 2011 met the $2008 \mathrm{BiOp}$ requirements of $\hat{S}>0.96$ with a standard error of $\widehat{\mathrm{SE}} \leq 0.015$. Furthermore, using just the conservative estimates of survival from the dam face to $\mathrm{rkm} 325$ for the virtual-release groups of steelhead also produced estimates $\geq 0.96$. 
Table 3.6. Survival, detection, and $\lambda$ parameters for the final model used to estimate dam passage survival for steelhead during the early part of the spring study (27 April - 16 May 2011) for 30\% spill conditions. Standard errors (SE) based on both the inverse hessian matrix and bootstrapping for key parameters $(\dagger)$ and only the inverse hessian matrix for associated parameters $\left(^{*}\right)$.

\begin{tabular}{|c|c|c|c|c|c|c|c|c|c|c|c|c|}
\hline \multirow[b]{2}{*}{ Release } & \multicolumn{2}{|c|}{ CR349 to 325} & \multicolumn{2}{|c|}{ CR325 to 309} & \multicolumn{2}{|c|}{ Release to CR309 } & \multicolumn{2}{|c|}{ CR309 to 275} & \multicolumn{2}{|c|}{ CR275 to 234} & \multicolumn{2}{|c|}{ CR234 to 161} \\
\hline & $\hat{S}$ & $\widehat{\mathrm{SE}}^{\dagger}$ & $\hat{S}$ & $\widehat{\mathrm{SE}}^{*}$ & $\hat{S}$ & $\widehat{\mathrm{SE}}^{\dagger}$ & $\hat{S}$ & $\widehat{\mathrm{SE}}^{*}$ & $\hat{S}$ & $\widehat{\mathrm{SE}}^{*}$ & $\hat{S}$ & $\widehat{\mathrm{SE}}^{*}$ \\
\hline$R_{1}$ & 0.9682 & 0.0059 & 0.9957 & 0.0023 & --- & --- & 0.9749 & 0.0054 & 0.9804 & 0.0048 & 0.9635 & 0.0071 \\
\hline$R_{2}$ & --- & --- & --- & --- & 0.9799 & 0.0057 & 0.9776 & 0.0057 & 0.9858 & 0.0046 & 0.9412 & 0.0094 \\
\hline$R_{3}$ & --- & --- & --- & --- & 0.9956 & 0.0039 & 0.9531 & 0.0101 & 0.9745 & 0.0077 & 0.9544 & 0.0106 \\
\hline
\end{tabular}

\begin{tabular}{|c|c|c|c|c|c|c|c|c|c|c|c|c|}
\hline \multirow[b]{2}{*}{ Release } & \multicolumn{2}{|c|}{ CR161 to 113} & \multicolumn{2}{|c|}{ CR325 } & \multicolumn{2}{|c|}{ CR309 } & \multicolumn{2}{|c|}{ CR275 } & \multicolumn{2}{|c|}{ CR 234} & \multicolumn{2}{|c|}{ CR161 } \\
\hline & $\hat{S}$ & $\widehat{\mathrm{SE}}^{*}$ & $\hat{p}$ & $\widehat{\mathrm{SE}}^{*}$ & $\hat{p}$ & $\widehat{\mathrm{SE}}^{*}$ & $\hat{p}$ & $\widehat{\mathrm{SE}}^{*}$ & $\hat{p}$ & $\widehat{\mathrm{SE}}^{*}$ & $\hat{p}$ & $\widehat{\mathrm{SE}}^{*}$ \\
\hline$R_{1}$ & 0.9959 & 0.0133 & 0.9944 & 0.0025 & 1.0000 & 0.0000 & 0.9799 & 0.0048 & 1.0000 & 0.0000 & 0.9323 & 0.0092 \\
\hline$R_{2}$ & 0.9876 & 0.0119 & --- & --- & 1.0000 & 0.0000 & 0.9985 & 0.0015 & 1.0000 & 0.0000 & 0.9497 & 0.0090 \\
\hline$R_{3}$ & 1.0035 & 0.0151 & --- & --- & 1.0000 & 0.0000 & 1.0000 & 0.0000 & 1.0000 & 0.0000 & 0.9598 & 0.0102 \\
\hline
\end{tabular}

\begin{tabular}{ccccc}
\hline & \multicolumn{2}{c}{ CR113 } & \multicolumn{2}{c}{ CR113-86 } \\
\cline { 2 - 5 } Release & $\hat{S}$ & $\widehat{\mathrm{SE}}^{*}$ & $\hat{\lambda}$ & $\widehat{\mathrm{SE}}^{*}$ \\
\hline$R_{1}$ & 0.7491 & 0.0182 & 0.7167 & 0.0185 \\
$R_{2}$ & 0.7746 & 0.0187 & 0.7956 & 0.0183 \\
$R_{3}$ & 0.7690 & 0.0242 & 0.7691 & 0.0242 \\
\hline
\end{tabular}


Table 3.7. Survival, detection, and $\lambda$ parameters for the final model used to estimate dam passage survival for steelhead during the early part of the spring study (27 April - 16 May 2011) for 40\% spill conditions. Standard errors (SE) based on both the inverse hessian matrix and bootstrapping for key parameters $(\dagger)$ and only the inverse hessian matrix for associated parameters $(*)$.

\begin{tabular}{|c|c|c|c|c|c|c|c|c|c|c|c|c|}
\hline \multirow[b]{2}{*}{ Release } & \multicolumn{2}{|c|}{ CR349 to 325} & \multicolumn{2}{|c|}{ CR325 to 309} & \multicolumn{2}{|c|}{ Release to CR309 } & \multicolumn{2}{|c|}{ CR309 to 275} & \multicolumn{2}{|c|}{ CR275 to 234} & \multicolumn{2}{|c|}{ CR234 to 161} \\
\hline & $\hat{S}$ & $\widehat{\mathrm{SE}}^{\dagger}$ & $\hat{S}$ & $\widehat{\mathrm{SE}}^{*}$ & $\hat{S}$ & $\widehat{\mathrm{SE}}^{\dagger}$ & $\hat{S}$ & $\widehat{\mathrm{SE}}^{*}$ & $\hat{S}$ & $\widehat{\mathrm{SE}}^{*}$ & $\hat{S}$ & $\widehat{\mathrm{SE}}^{*}$ \\
\hline$R_{1}$ & 0.9742 & 0.0066 & 0.9934 & 0.0034 & --- & --- & 0.9728 & 0.0069 & 0.9755 & 0.0066 & 0.9525 & 0.0094 \\
\hline$R_{2}$ & --- & --- & --- & --- & 0.9799 & 0.0057 & 0.9776 & 0.0057 & 0.9858 & 0.0046 & 0.9412 & 0.0094 \\
\hline$R_{3}$ & --- & --- & --- & --- & 0.9956 & 0.0039 & 0.9531 & 0.0101 & 0.9745 & 0.0077 & 0.9544 & 0.0106 \\
\hline
\end{tabular}

\begin{tabular}{|c|c|c|c|c|}
\hline \multirow[b]{2}{*}{ Release } & \multicolumn{2}{|c|}{ CR161 to 113} & \multicolumn{2}{|c|}{ CR325 } \\
\hline & $\hat{S}$ & $\widehat{\mathrm{SE}}^{*}$ & $\hat{p}$ & $\widehat{\mathrm{SE}}^{*}$ \\
\hline$R_{1}$ & 0.9990 & 0.0093 & 1.0000 & 0.0000 \\
\hline$R_{2}$ & 0.9876 & 0.0119 & --- & --- \\
\hline \multirow[t]{2}{*}{$R_{3}$} & 1.0035 & 0.0151 & --- & --- \\
\hline & \multicolumn{2}{|c|}{ CR113 } & \multicolumn{2}{|c|}{ CR113-86 } \\
\hline Release & $\hat{S}$ & $\widehat{\mathrm{SE}}^{*}$ & $\hat{\lambda}$ & $\widehat{\mathrm{SE}}^{*}$ \\
\hline$R_{1}$ & 0.8051 & 0.0191 & 0.8528 & 0.0176 \\
\hline$R_{2}$ & 0.7746 & 0.0187 & 0.7956 & 0.0183 \\
\hline$R_{3}$ & 0.7690 & 0.0242 & 0.7691 & 0.0242 \\
\hline
\end{tabular}


Table 3.8. Survival, detection, and $\lambda$ parameters for the final model used to estimate dam passage survival for steelhead during the latter part of the spring study (16 - 29 May 2011). Standard errors (SE) based on both the inverse hessian matrix and bootstrapping for key parameters $(\dagger)$ and only the inverse hessian matrix for associated parameters $(*)$.

\begin{tabular}{|c|c|c|c|c|c|c|c|c|c|c|c|c|}
\hline \multirow[b]{2}{*}{ Release } & \multicolumn{2}{|c|}{ CR349 to 325} & \multicolumn{2}{|c|}{ CR325 to 309} & \multicolumn{2}{|c|}{ Release to CR309 } & \multicolumn{2}{|c|}{ CR309 to 275} & \multicolumn{2}{|c|}{ CR275 to 234} & \multicolumn{2}{|c|}{ CR234 to 161} \\
\hline & $\hat{S}$ & $\widehat{\mathrm{SE}}^{\dagger}$ & $\hat{S}$ & $\widehat{\mathrm{SE}}^{*}$ & $\hat{S}$ & $\widehat{\mathrm{SE}}^{\dagger}$ & $\hat{S}$ & $\widehat{\mathrm{SE}}^{*}$ & $\hat{S}$ & $\widehat{\mathrm{SE}}^{*}$ & $\hat{S}$ & $\widehat{\mathrm{SE}}^{*}$ \\
\hline$R_{1}$ & 0.9857 & 0.0040 & 0.9903 & 0.0033 & --- & --- & 0.9876 & 0.0043 & 0.9927 & 0.0034 & 0.9455 & 0.0109 \\
\hline$R_{2}$ & --- & --- & --- & --- & 0.9853 & 0.0069 & 0.9736 & 0.0076 & 0.9974 & 0.0031 & 0.9401 & 0.0149 \\
\hline$R_{3}$ & --- & --- & --- & --- & 0.9894 & 0.0069 & 0.9831 & 0.0078 & 0.9957 & 0.0047 & 0.9584 & 0.0189 \\
\hline
\end{tabular}

\begin{tabular}{|c|c|c|c|c|c|c|c|c|c|c|c|c|}
\hline \multirow[b]{2}{*}{ Release } & \multicolumn{2}{|c|}{ CR161 to 113} & \multicolumn{2}{|c|}{ CR325 } & \multicolumn{2}{|c|}{ CR309 } & \multicolumn{2}{|c|}{ CR275 } & \multicolumn{2}{|c|}{ CR 234} & \multicolumn{2}{|c|}{ CR161 } \\
\hline & $\hat{S}$ & $\widehat{\mathrm{SE}}^{*}$ & $\hat{p}$ & $\widehat{\mathrm{SE}}^{*}$ & $\hat{p}$ & $\widehat{\mathrm{SE}}^{*}$ & $\hat{p}$ & $\widehat{\mathrm{SE}}^{*}$ & $\hat{p}$ & $\widehat{\mathrm{SE}}^{*}$ & $\hat{p}$ & $\widehat{\mathrm{SE}}^{*}$ \\
\hline$R_{1}$ & 0.9868 & 0.0362 & 0.9651 & 0.0061 & 0.9823 & 0.0044 & 0.7179 & 0.0150 & 1.0000 & 0.0000 & 0.8502 & 0.0141 \\
\hline$R_{2}$ & 0.9601 & 0.0486 & --- & --- & 0.9978 & 0.0022 & 0.6993 & 0.0214 & 1.0000 & 0.0000 & 0.8781 & 0.0183 \\
\hline$R_{3}$ & 1.0893 & 0.0843 & --- & --- & 0.9968 & 0.0032 & 0.6688 & 0.0266 & 1.0000 & 0.0000 & 0.8079 & 0.0260 \\
\hline
\end{tabular}

\begin{tabular}{ccccc}
\hline & \multicolumn{2}{c}{ CR113 } & \multicolumn{2}{c}{ CR113-86 } \\
\cline { 2 - 5 } Release & $\hat{S}$ & $\widehat{\mathrm{SE}}^{*}$ & $\hat{\lambda}$ & $\widehat{\mathrm{SE}}^{*}$ \\
\hline$R_{1}$ & 0.6479 & 0.0283 & 0.3401 & 0.0204 \\
$R_{2}$ & 0.6486 & 0.0392 & 0.3582 & 0.0293 \\
$R_{3}$ & 0.5952 & 0.0536 & 0.2565 & 0.0313 \\
\hline
\end{tabular}


Table 3.9. Survival, detection, and $\lambda$ parameters for the final model used to estimate dam passage survival for steelhead during the entire spring study (27 April - 29 May 2011). Standard errors (SE) based on both the inverse hessian matrix and bootstrapping for key parameters $(\dagger)$ and only the inverse hessian matrix for associated parameters $(*)$.

\begin{tabular}{|c|c|c|c|c|c|c|c|c|c|c|c|c|}
\hline \multirow[b]{2}{*}{ Release } & \multicolumn{2}{|c|}{ CR349 to 325} & \multicolumn{2}{|c|}{ CR325 to 309} & \multicolumn{2}{|c|}{ Release to CR309 } & \multicolumn{2}{|c|}{ CR309 to 275} & \multicolumn{2}{|c|}{ CR275 to 234} & \multicolumn{2}{|c|}{ CR234 to 161} \\
\hline & $\hat{S}$ & $\widehat{\mathrm{SE}}^{\dagger}$ & $\hat{S}$ & $\widehat{\mathrm{SE}}^{*}$ & $\hat{S}$ & $\widehat{\mathrm{SE}}^{\dagger}$ & $\hat{S}$ & $\widehat{\mathrm{SE}}^{*}$ & $\hat{S}$ & $\widehat{\mathrm{SE}}^{*}$ & $\hat{S}$ & $\widehat{\mathrm{SE}}^{*}$ \\
\hline$R_{1}$ & 0.9757 & 0.0032 & 0.9932 & 0.0017 & --- & --- & 0.9799 & 0.0031 & 0.9831 & 0.0029 & 0.9478 & 0.0052 \\
\hline$R_{2}$ & --- & --- & --- & --- & 0.9821 & 0.0043 & 0.9769 & 0.0046 & 0.9895 & 0.0033 & 0.9367 & 0.0080 \\
\hline$R_{3}$ & --- & --- & --- & --- & 0.9932 & 0.0034 & 0.9663 & 0.0068 & 0.9807 & 0.0054 & 0.9495 & 0.0092 \\
\hline
\end{tabular}

\begin{tabular}{|c|c|c|c|c|c|c|c|c|c|c|c|c|}
\hline \multirow[b]{2}{*}{ Release } & \multicolumn{2}{|c|}{ CR161 to 113} & \multicolumn{2}{|c|}{ CR325 } & \multicolumn{2}{|c|}{ CR309 } & \multicolumn{2}{|c|}{ CR275 } & \multicolumn{2}{|c|}{ CR 234} & \multicolumn{2}{|c|}{ CR161 } \\
\hline & $\hat{S}$ & $\widehat{\mathrm{SE}}^{*}$ & $\hat{p}$ & $\widehat{\mathrm{SE}}^{*}$ & $\hat{p}$ & $\widehat{\mathrm{SE}}^{*}$ & $\hat{p}$ & $\widehat{\mathrm{SE}}^{*}$ & $\hat{p}$ & $\widehat{\mathrm{SE}}^{*}$ & $\hat{p}$ & $\widehat{\mathrm{SE}}^{*}$ \\
\hline$R_{1}$ & 0.9693 & 0.0107 & 0.9845 & 0.0025 & 0.9923 & 0.0018 & 0.8822 & 0.0067 & 1.0000 & 0.0000 & 0.9175 & 0.0063 \\
\hline$R_{2}$ & 0.9528 & 0.0151 & --- & --- & 0.9991 & 0.0009 & 0.8772 & 0.0098 & 1.0000 & 0.0000 & 0.9247 & 0.0087 \\
\hline$R_{3}$ & 0.9938 & 0.0208 & --- & --- & 0.9987 & 0.0013 & 0.8596 & 0.0127 & 1.0000 & 0.0000 & 0.9003 & 0.0120 \\
\hline
\end{tabular}

\begin{tabular}{ccccc}
\hline & \multicolumn{2}{c}{ CR113 } & \multicolumn{2}{c}{ CR113-86 } \\
\cline { 2 - 5 } Release & $\hat{S}$ & $\widehat{\mathrm{SE}}^{*}$ & $\hat{\lambda}$ & $\widehat{\mathrm{SE}}^{*}$ \\
\hline$R_{1}$ & 0.7446 & 0.0122 & 0.6188 & 0.0123 \\
$R_{2}$ & 0.7457 & 0.0171 & 0.6397 & 0.0175 \\
$R_{3}$ & 0.7275 & 0.0223 & 0.5674 & 0.0219 \\
\hline
\end{tabular}




\subsubsection{Forebay-to-Tailrace Passage Survival}

The estimates of forebay-to-tailrace passage survival were calculated analogously to that of dam passage survival except the virtual-release group $\left(V_{1}\right)$ was composed of fish known to have arrived at the forebay (i.e., detection array rkm 351, Figure 2.1) rather than at the dam face. These season-wide survival estimates were based on all release data across the season, regardless of spill conditions. Using the same statistical model as was used in estimating dam passage survival, forebay-to-tailrace survival for yearling Chinook salmon was

$$
\hat{S}_{\text {forebay-to-tailrace }}=0.9646(\widehat{\mathrm{SE}}=0.0072)
$$

and for steelhead,

$$
\hat{S}_{\text {forebay-to-tailrace }}=0.9801(\widehat{\mathrm{SE}}=0.0062)
$$

\subsubsection{Forebay Residence Time}

The forebay residence time was calculated from the first detection of a smolt at the forebay BRZ array to the last detection at the dam $(2 \mathrm{~km})$. For yearling Chinook salmon, the mean forebay residence time was estimated to be $2.93 \mathrm{~h}(\widehat{\mathrm{SE}}=0.13)$ and for steelhead it was estimated to be $6.88 \mathrm{~h}(\widehat{\mathrm{SE}}=0.20)$ (Figure 3.11, Table 3.10). The distribution of forebay residence times indicates the modes for forebay residence times were between 0.5 and $1 \mathrm{~h}$ for both species. Median residence times were $1.42 \mathrm{~h}$ and $2.91 \mathrm{~h}$ for yearling Chinook salmon and steelhead, respectively (Table 3.10).

\subsubsection{Tailrace Egress Time}

The tailrace egress time was calculated based on the time from the last detection of fish at the double array at the face of John Day Dam to the last detection at the BRZ tailrace array (Figure 3.12). Mean tailrace egress time for yearling Chinook salmon smolts was estimated to be $\bar{t}=3.98 \mathrm{~h}$ ( $\widehat{\mathrm{SE}}=0.49)$. For steelhead smolts, mean tailrace egress time was estimated to be $\bar{t}=9.09 \mathrm{~h}(\widehat{\mathrm{SE}}=0.70)$. Median egress times were 0.57 and $0.58 \mathrm{~h}$ for yearling Chinook salmon and steelhead, respectively (Table 3.10).

\subsubsection{Spill Passage Efficiency}

SPE is defined as the fraction of the fish that passed through a hydroproject by the spillway. The double-detection array at the face of John Day Dam was used to identify and track fish as they entered the forebay. Using the observed counts and assuming detection efficiency was constant across the dam, the numbers of fish entering the various routes at John Day Dam were used to estimate SPE based on a binomial sampling model. For yearling Chinook smolts, $\mathrm{SPE}=0.6368$ (0.0093), and for steelhead smolts, SPE $=0.6278(0.0097)$. 
a. Yearling Chinook salmon

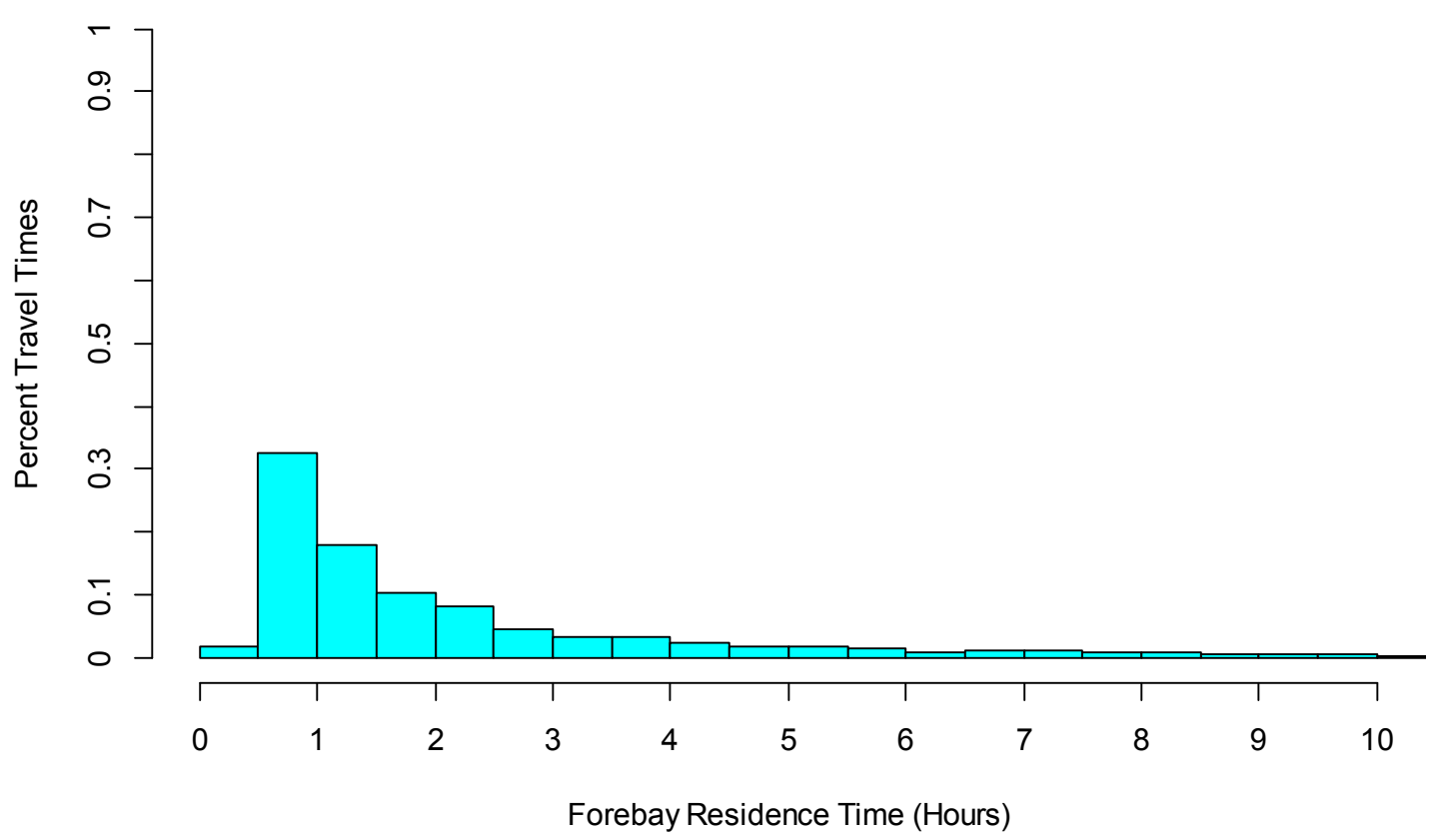

b. Steelhead

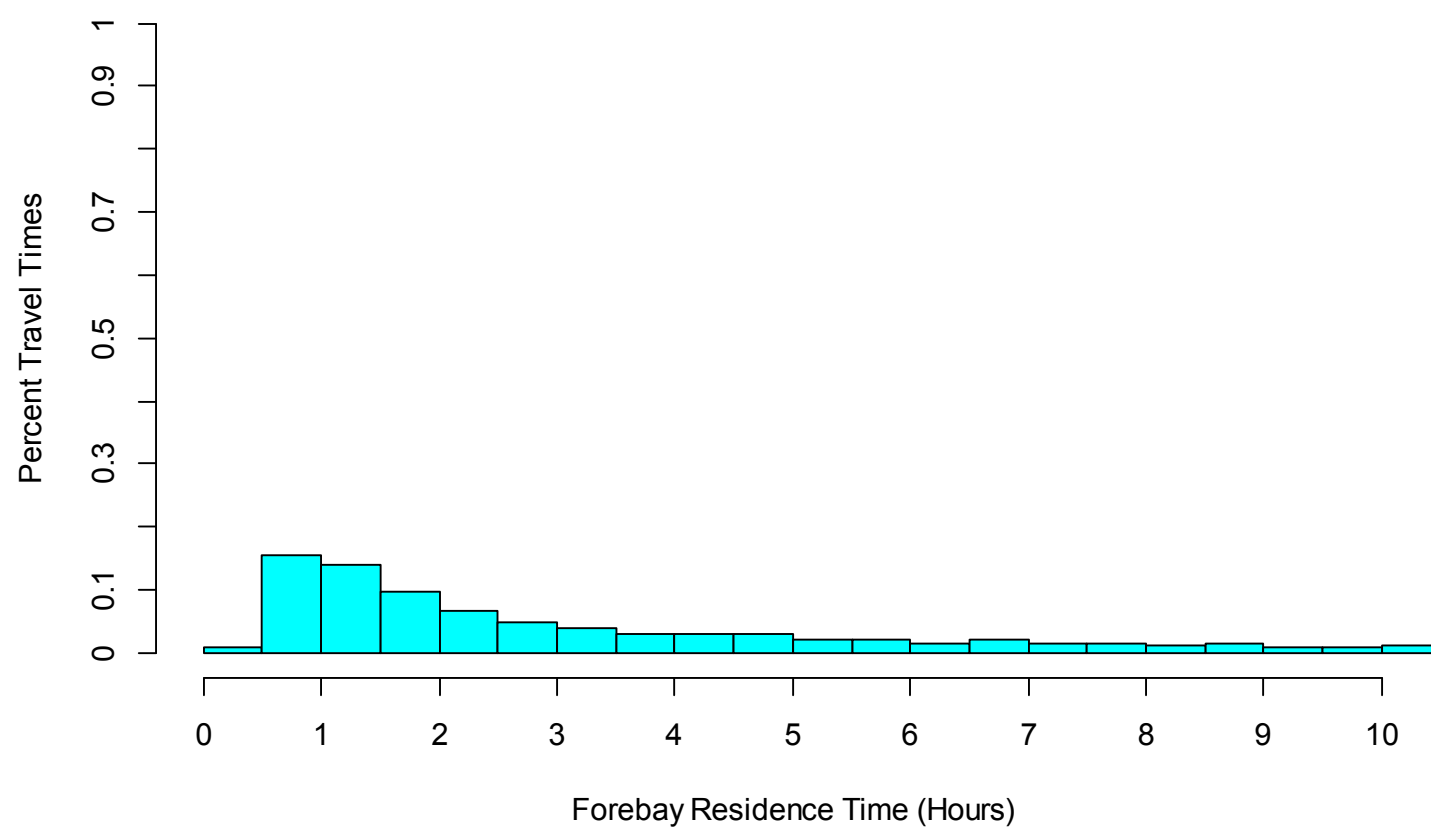

Figure 3.11. Distribution of forebay residence times for (a) yearling Chinook salmon and (b) steelhead smolts at John Day Dam, 2011. 
Table 3.10. Estimated mean and median forebay residence times (h) and mean and median tailrace egress times for yearling Chinook salmon and steelhead smolts at John Day Dam in 2011. (Standard errors in parentheses.)

\begin{tabular}{lll}
\hline \multicolumn{1}{c}{ Performance Measure } & Yearling Chinook Salmon & Steelhead \\
\hline Forebay Residence Time & & \\
- Mean & $2.93 \mathrm{~h}(0.13)$ & $6.88 \mathrm{~h}(0.20)$ \\
- Median & $1.42 \mathrm{~h}$ & $2.91 \mathrm{~h}$ \\
Tailrace Egress Time & & \\
- Mean & $3.98 \mathrm{~h}(0.49)$ & $9.09 \mathrm{~h}(0.70)$ \\
- Median & $0.57 \mathrm{~h}$ & $0.58 \mathrm{~h}$ \\
\hline
\end{tabular}

a. Yearling Chinook salmon

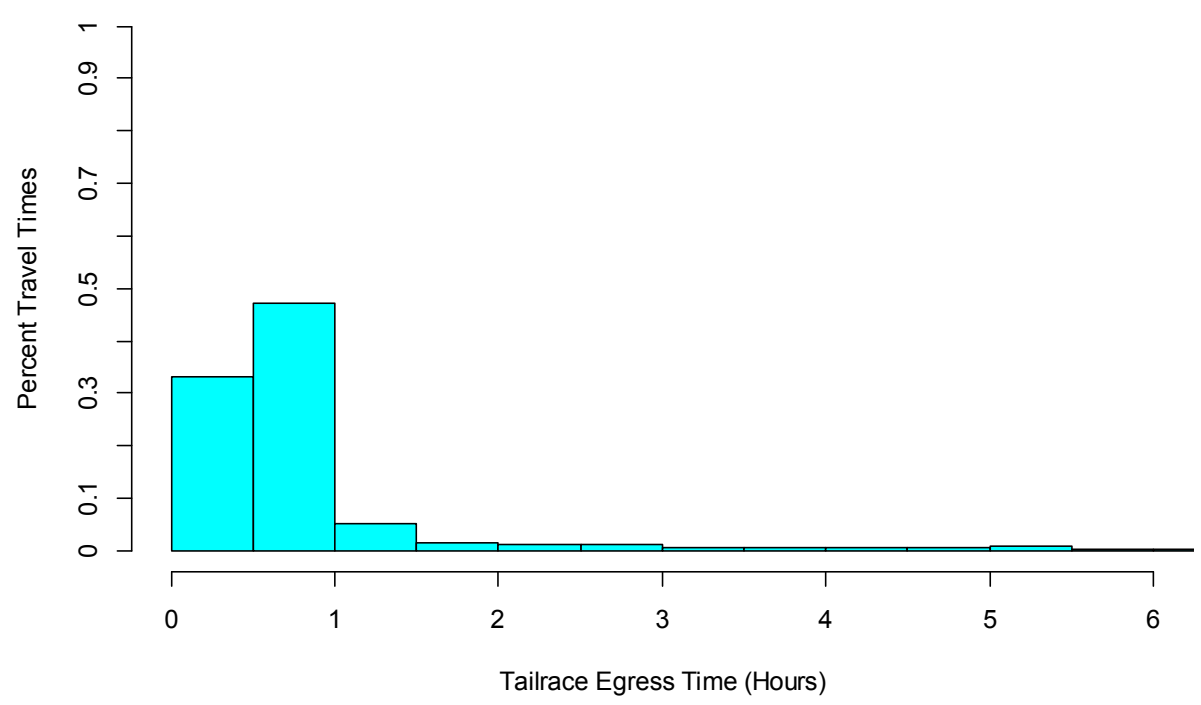

b. Steelhead

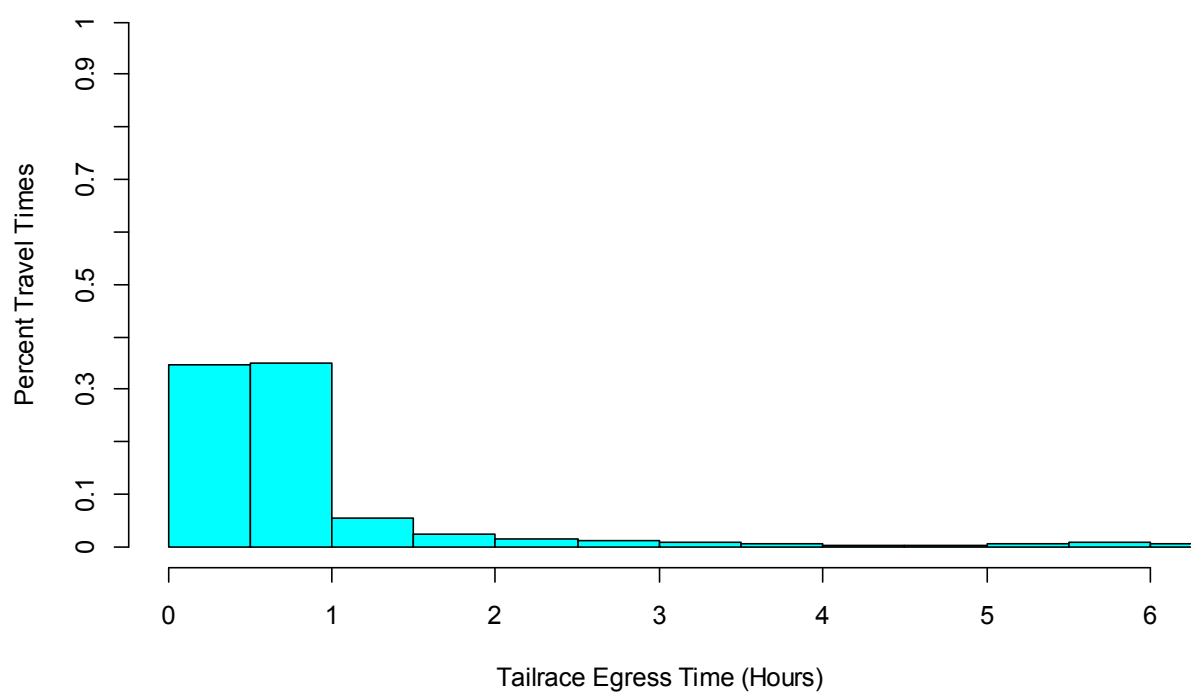

Figure 3.12. Distribution of tailrace egress times for (a) yearling Chinook salmon and (b) steelhead smolts at John Day Dam, 2011. 


\subsubsection{Fish Passage Efficiency}

FPE, called SPE in the Fish Accords, is the fraction of the fish that passed through non-turbine routes at the dam. As with SPE, the double-detection array at the face of John Day Dam was used to identify and track fish as they entered the dam. Using the observed counts and assuming constant detection efficiency across the face of the dam, the number of fish entering the various routes at John Day Dam were used to estimate FPE based on a binomial sampling model. For yearling Chinook salmon smolts at John Day Dam in 2011, fish passage efficiency is estimated to be FPE $=0.8848(0.0065)$, and for steelhead smolts, FPE $=0.9600$ (0.0039). 


\subsection{Discussion}

The discussion describes the conduct of the 2011 study, study performance, and compares 2011 estimates to comparable estimates in previous acoustic telemetry studies at John Day Dam.

\subsection{Study Conduct}

The many tests of assumptions (Appendix A) found the acoustic-tag study achieved good downstream mixing, with adequate tag-life and no evidence of adverse tagger or tag-lot effects. Those results suggest the assumptions of the virtual/paired-release model were fulfilled, permitting valid estimation of dam passage survival and related parameters.

Despite the high river flows and elevated spills at John Day Dam in the spring of 2011, the precision of the estimates of dam passage survival met the $2008 \mathrm{BiOp}$ standard of SE's $\leq 0.015$. This level of precision was obtained for both yearling Chinook salmon and steelhead, and regardless of the time frame over which survival was calculated because of high detection probabilities at multiple downstream detection arrays (Tables $3.2-3.9$ ).

\subsection{Study Performance}

The 2011 spring compliance studies at John Day Dam were interrupted by high river flow conditions and mandatory spill in excess of $40 \%$ during the latter half of the investigation. Although estimates of dam passage survival were higher for $40 \%$ spill than $30 \%$ spill during the early season for both yearling Chinook salmon and steelhead, there was no significant difference between early $30 \%$ spill, early $40 \%$ spill, and late season survival estimates (i.e., $P=0.6509$ yearling Chinook; $P=0.8632$ steelhead). In all cases, estimates of dam passage survival exceeded the $2008 \mathrm{BiOp}$ standard of $\hat{S} \geq 0.96$. For steelhead, the survival standard was also achieved using just the conservative survival estimates from the virtual releases from the dam face to the first detection array $24 \mathrm{~km}$ below the dam. This was also the situation in three of four cases for yearling Chinook salmon smolt.

The results of the investigation suggest compliance with BiOp survival standards at John Day Dam can and have been achieved with spill levels as low as 30\%. Higher spill levels did not significantly improve dam passage survival, although compliance was still achieved. Ultimately, acceptance of the spring studies at John Day Dam will depend on whether the fisheries community considers the 2011 flow and spill conditions normal. Certainly, flow and spill levels were atypically high during the latter part of the compliance studies. However, survival estimates were not significantly different between early season spill conditions and the later part of the study, and all met the survival standard of $\hat{S} \geq 0.96$.

\subsection{Comparison to Previous Acoustic Telemetry Studies}

Dam passage survival estimates in 2008 (Weiland et al. 2009) and 2011 (this study) were both estimated for the reach from the dam face to the tailrace array and can be compared directly (Table 4.1), even the though the survival models differed slightly. The model used in 2008 had a single tailrace reference release compared with the paired reference releases used in 2011. River flow was higher in 2011 than it was in 2008, as were survival estimates (Table 4.1). Estimates of dam-passage survival for 2009 and 2010 (Table 4.2) are not directly comparable because they were based on single-release survival 
models and therefore include additional losses of fish in the reach between the downstream end of the tailrace and the primary survival detection array at The Dalles Dam. Losses of tailrace-released fish in the tailwater in 2008 and 2011 ranged from 0.0059 to 0.0120 for yearling Chinook salmon and 0.0112 to 0.0270 for steelhead.

Table 4.1. Comparison of dam-passage survival estimates based on paired-release models 2008 and 2011.

\begin{tabular}{lcc}
\hline Fish Run & $2008^{\mathrm{a}}$ & 2011 \\
\hline Yearling Chinook Salmon & $0.957(\widehat{\mathrm{SE}}=0.0066)$ & $0.9676(\widehat{\mathrm{SE}}=0.0071)$ \\
Juvenile steelhead & $0.986(\widehat{\mathrm{SE}}=0.0097)$ & $0.9867(\widehat{\mathrm{SE}}=0.0061)$ \\
\hline (a) Weiland et al. (2009) & & \\
\hline
\end{tabular}

Table 4.2. Single-release estimates of dam-passage survival in 2009 and 2010.

\begin{tabular}{lcc}
\hline Fish Run & $2009^{\mathrm{a}}$ & $2010^{\mathrm{b}}$ \\
\hline Yearling Chinook Salmon & $0.9270(\widehat{\mathrm{SE}}=0.0051)$ & $0.937(\widehat{\mathrm{SE}}=0.005)$ \\
Juvenile steelhead & $0.9530(\widehat{\mathrm{SE}}=0.0041)$ & $0.950(\widehat{\mathrm{SE}}=0.005)$ \\
\hline
\end{tabular}

(a) Weiland et al. (2011)

(b) Weiland et al. (2012)

Both FPE and SPE were below average in 2011 because higher proportions of smolts passed through turbines and the juvenile bypass in 2011 than passed at those locations in 2008, 2009, and 2010 (Tables 4.3 and 4.4). During years of average or below-average flow, smolts arriving at the powerhouse may be able to avoid entrainment and pass at the spillway, but such avoidance is less likely when the powerhouse is fully loaded during a flood year like 2011.

Table 4.3. Comparison of passage metrics for yearling Chinook salmon (2008-2011).

\begin{tabular}{lcccc}
\hline \multicolumn{1}{c}{ Metric } & 2008 & 2009 & 2010 & 2011 \\
\hline Fish Passage Efficiency (FPE) & 92.1 & 93.4 & 96.1 & 88.5 \\
\hline Fish Guidance Efficiency (FGE) & 66.9 & 66.2 & 62.2 & 68.0 \\
\hline Spill Passage Efficiency (SPE) & 76.2 & 80.6 & 89.8 & 63.7 \\
\hline Surface Outlet Efficiency (SOE) & 23.6 & 27.1 & 56.7 & 23.9 \\
\hline Bypass Efficiency (BPE) & 15.9 & 12.8 & 6.4 & 24.5 \\
\hline
\end{tabular}

Table 4.4. Comparison of passage metrics for juvenile steelhead (2008-2011).

\begin{tabular}{lcccc}
\hline \multicolumn{1}{c}{ Metric } & 2008 & 2009 & 2010 & 2011 \\
\hline Fish Passage Efficiency (FPE) & 97.2 & 97.4 & 97.9 & 96.1 \\
\hline Fish Guidance Efficiency (FGE) & 88.9 & 89.0 & 80.9 & 89.4 \\
\hline Spill Passage Efficiency (SPE) & 74.4 & 76.3 & 88.7 & 62.9 \\
\hline Surface Outlet Efficiency (SOE) & 49.6 & 50.1 & 71.8 & 32.4 \\
\hline Bypass Efficiency (BPE) & 22.7 & 21.1 & 9.1 & 33.0 \\
\hline
\end{tabular}




\subsection{References}

3 Treaty Tribes-Action Agencies. 2008. Memorandum of Agreement Among the Umatilla, Warm Springs and Yakama Tribes, Bonneville Power Administration, U.S. Army Corps of Engineers, and U.S. Bureau of Reclamation, Portland, Oregon, April 4, 2008. Available at http://www.salmonrecovery.gov/ColumbiaBasinFishAccords.aspx.

Burnham KP, DR Anderson, GC White, C Brownie, and KH Pollock. 1987. "Design and analysis methods for fish survival experiments based on release-recapture." American Fisheries Society Monograph 5.

Li T, and JJ Anderson. 2009. "The vitality model: A way to understand population survival and demographic heterogeneity." Theoretical Population Biology 76:118-131.

Mantel N., and Haenszel, W. (1959), "Statistical Aspects of the Analysis of Data from Retrospective Studies of Disease," Journal of the National Cancer Institute, 22, 719-748.

Martinson R, G Kovalchuk, and D Ballinger. 2006. "Monitoring of downstream salmon and steelhead at federal hydroelectric facilities." 2005-2006 Annual Report, Project No. 198712700, BPA Report DOE/BP-00022085-2, Portland, Oregon.

Seber, GAF. 1982. The Estimation of Animal Abundance. MacMillan, New York.

Skalski JR, GE Johnson, and TJ Carlson. 2010a. "Compliance monitoring of juvenile yearling Chinook salmon and steelhead survival and passage at The Dalles Dam, Spring 2010." PNNL-19819, summary report submitted to the U.S. Army Corps of Engineers, Portland District, Portland, Oregon, by Pacific Northwest National Laboratory, Richland, Washington.

Skalski JR, RL Townsend, TW Steig, and S Hemstrom. 2010b. "Comparison of two alternative approaches for estimating dam passage survival using acoustic-tagged sockeye salmon smolts." North American Journal of Fisheries Management 30:831-839.

Townsend RL, JR Skalski, P Dillingham, and TW Steig. 2006. "Correcting bias in survival estimation resulting from tag failure in acoustic and radiotelemetry studies." Journal of Agricultural Biology and Environmental Statistics 11(2):183-196.

Weiland MA, GR Ploskey, JS Hughes, and fifteen co-authors. 2009. Acoustic Telemetry Evaluation of Juvenile Salmonid Passage and Survival at John Day Dam with Emphasis on the Prototype Surface Flow Outlet, 2008. PNNL-18890, final report submitted to the U.S. Army Corps of Engineers, Portland District, Portland, Oregon, by Pacific Northwest National Laboratory, Richland, Washington.

Weiland MA, GR Ploskey, JS Hughes, and sixteen coauthors. 2011. Acoustic Telemetry Evaluation of Juvenile Salmonid Passage and Survival Proportions at John Day Dam, 2009. PNNL-20766, final report submitted to the U.S. Army Corps of Engineers, Portland District, Portland, Oregon, by Pacific Northwest National Laboratory, Richland, Washington.

Weiland MA, GR Ploskey, CM Woodley, and sixteen coauthors. 2012. Acoustic Telemetry Evaluation of Juvenile Salmonid Passage and Survival at John Day Dam, 2010. Draft Technical Report submitted to the U.S. Army Corps of Engineers, Portland District, Portland, Oregon, by Pacific Northwest National Laboratory, Richland, Washington. 
Appendix A

Tests of Assumptions 


\section{Appendix A}

\section{Tests of Assumptions}

\section{A.1 Tagger Effects}

All of the data from the seven releases associated with the three-dam study were examined for tagger effects. This was done because of the interrelationship between the multiple releases and estimation of dam passage survival at a specific location and to increase the statistical power to detect effects.

To minimize any tagger effects that might go undetected, tagger effort should be balanced across release locations and within replicates. A total of eight taggers participated in the tagging of yearling Chinook salmon and steelhead. Tagger effort was found to be balanced across the seven release locations regardless whether the data were pooled across species $\left(P\left(\chi_{42}^{2} \geq 27.70\right)=0.9562\right)$ or analyzed separately by yearling Chinook salmon $\left(P\left(\chi_{42}^{2} \geq 22.68\right)=0.9935\right)$ or steelhead $\left(P\left(\chi_{42}^{2} \geq 10.62\right)=1.00\right)$ (Table A.1).

Tagger effort also examined release locations within each of the 32 replicate releases conducted over the course of the season (Table A.2). Tagger effort was found to be balanced within replicates 1, 2, 5, 6, $9,10,13,14,17,18,21,22,25,26,29$, and 30 ( $P \geq 0.9982)$. To accommodate staff time off during the month-long study, tagger effort was conditionally balanced within the individual project releases (i.e., R1-R3, R4-R5, and R6-R7) for the remaining replicates ( $P \geq 0.7459)$ (Table A.2). This conditional and unconditional balance within replicates is the reason for the overall balanced displayed in Table A.1. To minimize the number of contingency tables presented, results in Table A.2 are pooled across species.

To test for tagger effects, reach survivals and cumulative survivals were calculated for fish tagged by different staff members on a release location (i.e., R1, ., R7) and species basis (Table A.3). Of the 56 tests of homogeneous reach survivals, 7 were found significant at $\alpha=0.10$ (i.e., $12.5 \%$ ). In expectation, $10 \%$ of the 56 tests (i.e., 5.6) would be significant at $\alpha=0.10$ when no effect exists. There was no consistent pattern, with two taggers responsible for 2 of 7 significant results each, and three taggers responsible for 1 significant result each. Similarly, only 2 of 54 (3.7\%) tests of the homogeneous cumulative survivals were found to be significant at $\alpha=0.10$. Therefore, fish tagged by all taggers were considered acceptable for the survival analyses. 
Table A.1. Numbers of yearling Chinook salmon and steelhead tagged by each staff member by release locations (R1, R2, .., R7). Chi-square tests of homogeneity were not significant.

a. Yearling Chinook salmon and steelhead releases pooled

\begin{tabular}{ccccccccc}
\hline \multirow{2}{*}{$\begin{array}{c}\text { Release } \\
\text { location }\end{array}$} & \multicolumn{7}{c}{ Tagger } \\
\cline { 2 - 9 } & Amanda & Kate & Kathleen & Kyle & MaryBeth & Rhonda & Shon & Tyrell \\
\hline R1-CR390 & 581 & 576 & 668 & 569 & 528 & 456 & 899 & 820 \\
R2-CR346 & 279 & 254 & 302 & 263 & 293 & 227 & 388 & 383 \\
R3-CR325 & 193 & 173 & 197 & 176 & 196 & 148 & 248 & 265 \\
R4-CR307 & 195 & 176 & 197 & 168 & 200 & 150 & 249 & 264 \\
R5-CR275 & 190 & 172 & 195 & 176 & 201 & 152 & 242 & 271 \\
R6-CR233 & 189 & 179 & 190 & 179 & 196 & 150 & 246 & 261 \\
R7-CR161 & 192 & 178 & 196 & 179 & 191 & 141 & 246 & 265 \\
\hline & & & & & & & $P\left(\chi_{42}^{2} \geq 27.70\right)=0.9562$
\end{tabular}

b. Yearling Chinook salmon

\begin{tabular}{ccrcrcccc}
\hline \multirow{2}{*}{$\begin{array}{c}\text { Release } \\
\text { location }\end{array}$} & \multicolumn{8}{c}{ Tagger } \\
\cline { 2 - 9 } & Amanda & Kate & Kathleen & Kyle & MaryBeth & Rhonda & Shon & Tyrell \\
\hline R1-CR390 & 280 & 292 & 335 & 284 & 252 & 216 & 447 & 404 \\
R2-CR346 & 136 & 127 & 147 & 133 & 149 & 113 & 197 & 191 \\
R3-CR325 & 98 & 88 & 97 & 84 & 99 & 73 & 125 & 135 \\
R4-CR307 & 95 & 85 & 98 & 84 & 102 & 77 & 123 & 135 \\
R5-CR275 & 95 & 84 & 93 & 86 & 104 & 76 & 122 & 139 \\
R6-CR233 & 94 & 90 & 97 & 86 & 101 & 75 & 125 & 130 \\
R7-CR161 & 93 & 91 & 102 & 90 & 97 & 67 & 122 & 132 \\
\hline & & & & & & & $P\left(\chi_{42}^{2} \geq 22.68\right)=0.9935$
\end{tabular}

c. Steelhead

\begin{tabular}{crrrrrrrc}
\hline \multirow{2}{*}{$\begin{array}{c}\text { Release } \\
\text { location }\end{array}$} & \multicolumn{8}{c}{ Tagger } \\
\cline { 2 - 8 } & Amanda & Kate & Kathleen & Kyle & MaryBeth & Rhonda & Shon & Tyrell \\
\hline R1-CR390 & 301 & 284 & 333 & 285 & 276 & 240 & 452 & 416 \\
R2-CR346 & 143 & 127 & 155 & 130 & 144 & 114 & 191 & 192 \\
R3-CR325 & 95 & 85 & 100 & 92 & 97 & 75 & 123 & 130 \\
R4-CR307 & 100 & 91 & 99 & 84 & 98 & 73 & 126 & 129 \\
R5-CR275 & 95 & 88 & 102 & 90 & 97 & 76 & 120 & 132 \\
R6-CR233 & 95 & 89 & 93 & 93 & 95 & 75 & 121 & 131 \\
R7-CR161 & 99 & 87 & 94 & 89 & 94 & 74 & 124 & 133 \\
\hline & & & & & & & $P\left(\chi_{42}^{2} \geq 10.62\right) \doteq 1.00$
\end{tabular}


Table A.2. Contingency tables with number of fish tagged by each staff member per release location within a replicate release. A total of 32 replicate day or nighttime releases were performed over the course of the 2011 investigations. Results of the chi-square tests of homogeneity presented for each table.

a. Replicate 1

\begin{tabular}{ccccc}
\hline Release & Kate & Kathleen & Kyle & Shon \\
\hline R1-CR390 & 35 & 40 & 31 & 54 \\
R2-CR346 & 14 & 21 & 16 & 25 \\
R3-CR325 & 10 & 14 & 10 & 16 \\
R4-CR307 & 10 & 14 & 11 & 15 \\
R5-CR275 & 11 & 12 & 13 & 14 \\
R6-CR233 & 10 & 12 & 12 & 16 \\
R7-CR161 & 9 & 12 & 11 & 18 \\
\hline Chi-square $=2.7577$ & DF $=18$ & \multicolumn{2}{c}{$P$-value $=1$} \\
\hline
\end{tabular}

b. Replicate 2

\begin{tabular}{ccccc}
\hline Release & Kate & Kathleen & Kyle & Shon \\
\hline R1-CR390 & 36 & 44 & 32 & 51 \\
R2-CR346 & 17 & 20 & 14 & 24 \\
R3-CR325 & 12 & 12 & 10 & 16 \\
R4-CR307 & 12 & 12 & 11 & 15 \\
R5-CR275 & 10 & 14 & 11 & 15 \\
R6-CR233 & 11 & 12 & 11 & 15 \\
R7-CR161 & 10 & 12 & 11 & 15 \\
\hline Chi-square $=1.2674$ & DF $=18$ & & $P$-value $=1$ \\
\hline
\end{tabular}

c. Replicate 3

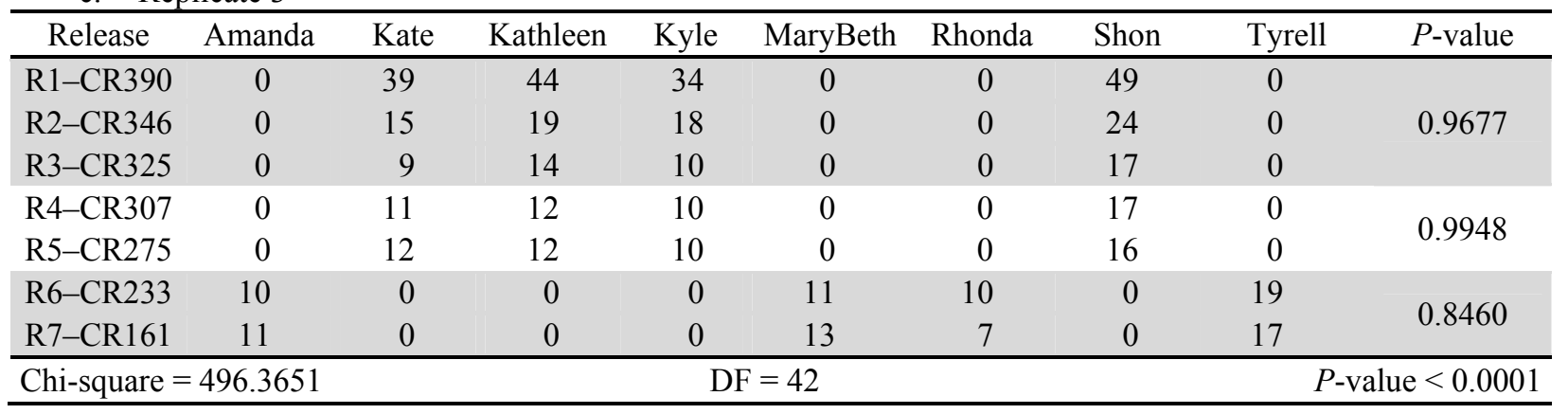

d. Replicate 4

\begin{tabular}{|c|c|c|c|c|c|c|c|c|c|}
\hline Release & Amanda & Kate & Kathleen & Kyle & MaryBeth & Rhonda & Shon & Tyrell & $P$-value \\
\hline R1-CR390 & 0 & 34 & 42 & 37 & 0 & 0 & 49 & 0 & \multirow{3}{*}{0.9977} \\
\hline R2-CR346 & 0 & 14 & 21 & 17 & 0 & 0 & 24 & 0 & \\
\hline R3-CR325 & 0 & 10 & 12 & 11 & 0 & 0 & 17 & 0 & \\
\hline R4-CR307 & 0 & 9 & 13 & 12 & 0 & 0 & 16 & 0 & \multirow{2}{*}{0.9318} \\
\hline R5-CR275 & 0 & 11 & 11 & 11 & 0 & 0 & 17 & 0 & \\
\hline R6-CR233 & 12 & 0 & 0 & 0 & 13 & 8 & 0 & 17 & \multirow{2}{*}{0.7459} \\
\hline R7-CR161 & 12 & 0 & 0 & 0 & 9 & 11 & 0 & 18 & \\
\hline Chi-square = & 495.4415 & \multicolumn{6}{|c|}{$\mathrm{DF}=42$} & \multicolumn{2}{|c|}{$P$-value $<0.0001$} \\
\hline
\end{tabular}


Table A.2. (contd)

e. Replicate 5

\begin{tabular}{ccccc}
\hline Release & Amanda & MaryBeth & Rhonda & Tyrell \\
\hline R1-CR390 & 37 & 31 & 24 & 71 \\
R2-CR346 & 16 & 18 & 15 & 26 \\
R3-CR325 & 11 & 11 & 10 & 18 \\
R4-CR307 & 10 & 11 & 9 & 20 \\
R5-CR275 & 11 & 11 & 9 & 19 \\
R6-CR233 & 12 & 12 & 9 & 17 \\
R7-CR161 & 13 & 11 & 9 & 16 \\
\hline Chi-square $=4.8581$ & DF $=18$ & \multicolumn{2}{c}{$P$-value $=0.9991$} \\
\hline
\end{tabular}

f. Replicate 6

\begin{tabular}{ccccc}
\hline Release & Amanda & MaryBeth & Rhonda & Tyrell \\
\hline R1-CR390 & 37 & 40 & 29 & 58 \\
R2-CR346 & 17 & 17 & 14 & 28 \\
R3-CR325 & 11 & 10 & 10 & 19 \\
R4-CR307 & 12 & 11 & 9 & 18 \\
R5-CR275 & 11 & 10 & 10 & 19 \\
R6-CR233 & 11 & 13 & 9 & 17 \\
R7-CR161 & 12 & 10 & 9 & 16 \\
\hline Chi-square $=1.5118$ & DF $=18$ & & $P$-value $=1$ \\
\hline
\end{tabular}

g. $\quad$ Replicate 7

\begin{tabular}{cccccccccc}
\hline Release & Amanda & Kate & Kathleen & Kyle & MaryBeth & Rhonda & Shon & Tyrell & $P$-value \\
\hline R1-CR390 & 36 & 0 & 0 & 0 & 37 & 29 & 0 & 62 & \\
R2-CR346 & 19 & 0 & 0 & 0 & 18 & 12 & 0 & 27 & 0.9966 \\
R3-CR325 & 12 & 0 & 0 & 0 & 12 & 9 & 0 & 17 & \\
R4-CR307 & 12 & 0 & 0 & 0 & 12 & 10 & 0 & 15 & 0.9449 \\
R5-CR275 & 12 & 0 & 0 & 0 & 13 & 8 & 0 & 17 & \\
R6-CR233 & 0 & 11 & 12 & 10 & 0 & 0 & 17 & 0 & 0.9176 \\
R7-CR161 & 0 & 10 & 15 & 10 & 0 & 0 & 15 & 0 & \\
\hline Chi-square $=493.4409$ & \multicolumn{10}{c}{ DF $=42$} & & & \\
\hline
\end{tabular}

h. $\quad$ Replicate 8

\begin{tabular}{cccccccccc}
\hline Release & Amanda & Kate & Kathleen & Kyle & MaryBeth & Rhonda & Shon & Tyrell & $P$-value \\
\hline R1-CR390 & 36 & 0 & 0 & 0 & 37 & 30 & 0 & 61 & \\
R2-CR346 & 15 & 0 & 0 & 0 & 17 & 14 & 0 & 28 & 0.9970 \\
R3-CR325 & 12 & 0 & 0 & 0 & 11 & 8 & 0 & 16 & \\
R4-CR307 & 13 & 0 & 0 & 0 & 12 & 10 & 0 & 15 & 0.9747 \\
R5-CR275 & 12 & 0 & 0 & 0 & 12 & 9 & 0 & 17 & \\
R6-CR233 & 0 & 10 & 13 & 11 & 0 & 0 & 15 & 0 & 0.9910 \\
R7-CR161 & 0 & 10 & 14 & 10 & 0 & 0 & 16 & 0 & $P$-value $<0.0001$ \\
\hline
\end{tabular}


Table A.2. (contd)

i. Replicate 9

\begin{tabular}{ccccc}
\hline Release & Kate & Kathleen & Kyle & Shon \\
\hline R1-CR390 & 35 & 43 & 38 & 48 \\
R2-CR346 & 16 & 20 & 16 & 24 \\
R3-CR325 & 10 & 13 & 11 & 16 \\
R4-CR307 & 11 & 14 & 9 & 16 \\
R5-CR275 & 11 & 13 & 10 & 16 \\
R6-CR233 & 10 & 11 & 11 & 15 \\
R7-CR161 & 11 & 12 & 11 & 16 \\
\hline Chi-square $=1.2239$ & DF $=18$ & & $P$-value $=1$ \\
\hline
\end{tabular}

j. Replicate 10

\begin{tabular}{ccccc}
\hline Release & Kate & Kathleen & Kyle & Shon \\
\hline R1-CR390 & 33 & 43 & 36 & 52 \\
R2-CR346 & 14 & 21 & 16 & 25 \\
R3-CR325 & 11 & 14 & 10 & 15 \\
R4-CR307 & 10 & 14 & 10 & 16 \\
R5-CR275 & 8 & 13 & 11 & 15 \\
R6-CR233 & 10 & 13 & 12 & 15 \\
R7-CR161 & 10 & 14 & 11 & 15 \\
\hline Chi-square $=1.0171$ & DF $=18$ & & $P$-value $=1$ \\
\hline
\end{tabular}

k. Replicate 11

\begin{tabular}{cccccccccc}
\hline Release & Amanda & Kate & Kathleen & Kyle & MaryBeth & Rhonda & Shon & Tyrell & $P$-value \\
\hline R1-CR390 & 0 & 34 & 43 & 36 & 0 & 0 & 51 & 0 & \\
R2-CR346 & 0 & 16 & 21 & 15 & 0 & 0 & 24 & 0 & 0.9939 \\
R3-CR325 & 0 & 12 & 11 & 11 & 0 & 0 & 16 & 0 & \\
R4-CR307 & 0 & 11 & 14 & 10 & 0 & 0 & 15 & 0 & 0.9832 \\
R5-CR275 & 0 & 10 & 15 & 11 & 0 & 0 & 14 & 0 & \\
R6-CR233 & 12 & 0 & 0 & 0 & 12 & 10 & 0 & 15 & 0.9900 \\
R7-CR161 & 13 & 0 & 0 & 0 & 12 & 9 & 0 & 16 & \multicolumn{7}{c}{$P$-value $<0.0001$} \\
\hline Chi-square $=491.1992$ & \multicolumn{7}{c}{ DF $=42$} & &
\end{tabular}

1. Replicate 12

\begin{tabular}{cccccccccc}
\hline Release & Amanda & Kate & Kathleen & Kyle & MaryBeth & Rhonda & Shon & Tyrell & $P$-value \\
\hline R1-CR390 & 0 & 34 & 46 & 36 & 0 & 0 & 48 & 0 & \\
R2-CR346 & 0 & 15 & 21 & 17 & 0 & 0 & 23 & 0 & 0.9999 \\
R3-CR325 & 0 & 11 & 13 & 11 & 0 & 0 & 15 & 0 & \\
R4-CR307 & 0 & 13 & 14 & 10 & 0 & 0 & 13 & 0 & 0.8539 \\
R5-CR275 & 0 & 12 & 11 & 13 & 0 & 0 & 13 & 0 & \\
R6-CR233 & 13 & 0 & 0 & 0 & 11 & 9 & 0 & 16 & 0.9295 \\
R7-CR161 & 12 & 0 & 0 & 0 & 12 & 7 & 0 & 18 & \\
\hline Chi-square $=491.908$ & \multicolumn{8}{c}{ DF $=42$} & \multicolumn{7}{c}{$P$-value $<0.0001$} \\
\hline
\end{tabular}


Table A.2. (contd)

m. Replicate 13

\begin{tabular}{cccccc}
\hline Release & Amanda & MaryBeth & Rhonda & Shon & Tyrell \\
\hline R1-CR390 & 34 & 0 & 27 & 50 & 51 \\
R2-CR346 & 19 & 17 & 16 & 0 & 24 \\
R3-CR325 & 12 & 11 & 10 & 0 & 17 \\
R4-CR307 & 12 & 12 & 9 & 0 & 17 \\
R5-CR275 & 12 & 12 & 9 & 0 & 17 \\
R6-CR233 & 13 & 13 & 7 & 0 & 17 \\
R7-CR161 & 12 & 11 & 8 & 0 & 18 \\
\hline Chi-square $=140.8547$ & DF $=24$ & \multicolumn{4}{c}{$P$-value $<0.0001$} \\
\hline
\end{tabular}

n. Replicate 14

\begin{tabular}{cccccc}
\hline Release & Amanda & MaryBeth & Rhonda & Shon & Tyrell \\
\hline R1-CR390 & 35 & 0 & 31 & 48 & 50 \\
R2-CR346 & 18 & 19 & 14 & 0 & 23 \\
R3-CR325 & 13 & 12 & 9 & 0 & 16 \\
R4-CR307 & 13 & 13 & 10 & 0 & 14 \\
R5-CR275 & 12 & 12 & 9 & 0 & 17 \\
R6-CR233 & 12 & 11 & 10 & 0 & 17 \\
R7-CR161 & 14 & 13 & 7 & 0 & 16 \\
\hline Chi-square $=137.8706$ & DF $=24$ & \multicolumn{2}{c}{$P$-value $<0.0001$} \\
\hline
\end{tabular}

o. Replicate 15

\begin{tabular}{|c|c|c|c|c|c|c|c|c|c|}
\hline Release & Amanda & Kate & Kathleen & Kyle & MaryBeth & Rhonda & Shon & Tyrell & $P$-value \\
\hline R1-CR390 & 41 & 0 & 0 & 0 & 39 & 32 & 0 & 52 & \multirow{3}{*}{0.9873} \\
\hline R2-CR346 & 20 & 0 & 0 & 0 & 20 & 13 & 0 & 23 & \\
\hline R3-CR325 & 13 & 0 & 0 & 0 & 11 & 8 & 0 & 18 & \\
\hline R4-CR307 & 13 & 0 & 0 & 0 & 12 & 8 & 0 & 17 & \multirow{2}{*}{0.9345} \\
\hline R5-CR275 & 14 & 0 & 0 & 0 & 11 & 10 & 0 & 15 & \\
\hline R6-CR233 & 0 & 13 & 11 & 10 & 0 & 0 & 16 & 0 & \multirow{2}{*}{0.9161} \\
\hline R7-CR161 & 0 & 10 & 12 & 11 & 0 & 0 & 17 & 0 & \\
\hline \multicolumn{3}{|c|}{ Chi-square $=494.3843$} & & $\mathrm{DF}=4$ & & & & & $<0.0001$ \\
\hline
\end{tabular}

p. Replicate 16

\begin{tabular}{cccccccccc}
\hline Release & Amanda & Kate & Kathleen & Kyle & MaryBeth & Rhonda & Shon & Tyrell & $P$-value \\
\hline R1-CR390 & 40 & 0 & 0 & 0 & 39 & 32 & 0 & 52 & \\
R2-CR346 & 17 & 0 & 0 & 0 & 17 & 15 & 0 & 26 & 0.9959 \\
R3-CR325 & 13 & 0 & 0 & 0 & 12 & 8 & 0 & 17 & \\
R4-CR307 & 12 & 0 & 0 & 0 & 12 & 9 & 0 & 17 & 0.9933 \\
R5-CR275 & 12 & 0 & 0 & 0 & 12 & 8 & 0 & 18 & \\
R6-CR233 & 0 & 11 & 11 & 10 & 0 & 0 & 15 & 0 & 0.9883 \\
R7-CR161 & 0 & 12 & 10 & 11 & 0 & 0 & 15 & 0 & \\
\hline \multicolumn{7}{l}{ Chi-square $=484.8889$} & \multicolumn{7}{c}{ DF $=42$} & & & & & \\
\hline
\end{tabular}


Table A.2. (contd)

q. Replicate 17

\begin{tabular}{ccccc}
\hline Release & Kate & Kathleen & Kyle & Shon \\
\hline R1-CR390 & 32 & 42 & 33 & 55 \\
R2-CR346 & 15 & 17 & 18 & 23 \\
R3-CR325 & 12 & 10 & 12 & 16 \\
R4-CR307 & 11 & 11 & 11 & 17 \\
R5-CR275 & 12 & 9 & 12 & 17 \\
R6-CR233 & 11 & 12 & 10 & 16 \\
R7-CR161 & 12 & 10 & 11 & 15 \\
\hline Chi-square $=3.1892$ & DF $=18$ & & $P$-value $=1$ \\
\hline
\end{tabular}

r. Replicate 18

\begin{tabular}{ccccc}
\hline Release & Kate & Kathleen & Kyle & Shon \\
\hline R1-CR390 & 36 & 42 & 35 & 50 \\
R2-CR346 & 17 & 16 & 16 & 26 \\
R3-CR325 & 11 & 11 & 12 & 15 \\
R4-CR307 & 12 & 11 & 9 & 18 \\
R5-CR275 & 11 & 11 & 11 & 16 \\
R6-CR233 & 12 & 11 & 13 & 14 \\
R7-CR161 & 12 & 12 & 12 & 14 \\
\hline Chi-square $=2.7843$ & DF $=18$ & & $P$-value $=1$ \\
\hline
\end{tabular}

S. Replicate 19

\begin{tabular}{|c|c|c|c|c|c|c|c|c|c|}
\hline Release & Amanda & Kate & Kathleen & Kyle & MaryBeth & Rhonda & Shon & Tyrell & $P$-value \\
\hline R1-CR390 & 0 & 41 & 36 & 38 & 0 & 0 & 49 & 0 & \multirow{3}{*}{0.9882} \\
\hline R2-CR346 & 0 & 17 & 18 & 16 & 0 & 0 & 25 & 0 & \\
\hline R3-CR325 & 0 & 11 & 12 & 13 & 0 & 0 & 14 & 0 & \\
\hline R4-CR307 & 0 & 11 & 11 & 12 & 0 & 0 & 16 & 0 & \multirow{2}{*}{0.9352} \\
\hline R5-CR275 & 0 & 13 & 12 & 10 & 0 & 0 & 15 & 0 & \\
\hline R6-CR233 & 14 & 0 & 0 & 0 & 12 & 8 & 0 & 16 & \multirow{2}{*}{0.9704} \\
\hline R7-CR161 & 12 & 0 & 0 & 0 & 12 & 9 & 0 & 17 & \\
\hline \multicolumn{3}{|c|}{ Chi-square $=492.9525$} & & $\mathrm{~F}=4$ & & & & & $<0.0001$ \\
\hline
\end{tabular}

t. Replicate 20

\begin{tabular}{cccccccccc}
\hline Release & Amanda & Kate & Kathleen & Kyle & MaryBeth & Rhonda & Shon & Tyrell & $P$-value \\
\hline R1-CR390 & 0 & 39 & 37 & 36 & 0 & 0 & 52 & 0 & \\
R2-CR346 & 0 & 18 & 16 & 17 & 0 & 0 & 24 & 0 & 0.9996 \\
R3-CR325 & 0 & 11 & 12 & 12 & 0 & 0 & 15 & 0 & \\
R4-CR307 & 0 & 12 & 12 & 12 & 0 & 0 & 14 & 0 & 0.9836 \\
R5-CR275 & 0 & 11 & 13 & 11 & 0 & 0 & 15 & 0 & \\
R6-CR233 & 12 & 0 & 0 & 0 & 12 & 10 & 0 & 16 & 0.9705 \\
R7-CR161 & 12 & 0 & 0 & 0 & 12 & 8 & 0 & 17 & \\
\hline
\end{tabular}


Table A.2. (contd)

u. Replicate 21

\begin{tabular}{ccccc}
\hline Release & Amanda & MaryBeth & Rhonda & Tyrell \\
\hline R1-CR390 & 41 & 41 & 29 & 53 \\
R2-CR346 & 20 & 18 & 14 & 24 \\
R3-CR325 & 12 & 13 & 9 & 16 \\
R4-CR307 & 13 & 14 & 8 & 15 \\
R5-CR275 & 11 & 15 & 8 & 16 \\
R6-CR233 & 11 & 14 & 10 & 15 \\
R7-CR161 & 11 & 12 & 8 & 17 \\
\hline Chi-square $=1.8491$ & DF $=18$ & \multicolumn{3}{c}{$P$-value $=1$} \\
\hline
\end{tabular}

v. Replicate 22

\begin{tabular}{ccccc}
\hline Release & Amanda & MaryBeth & Rhonda & Tyrell \\
\hline R1-CR390 & 39 & 40 & 32 & 48 \\
R2-CR346 & 20 & 18 & 15 & 23 \\
R3-CR325 & 10 & 15 & 10 & 15 \\
R4-CR307 & 12 & 14 & 9 & 15 \\
R5-CR275 & 12 & 14 & 8 & 16 \\
R6-CR233 & 10 & 13 & 10 & 17 \\
R7-CR161 & 12 & 11 & 10 & 17 \\
\hline Chi-square $=2.6222$ & \multicolumn{5}{c}{ DF $=18$} & $P$-value $=1$ \\
\hline
\end{tabular}

w. Replicate 23

\begin{tabular}{cccccccccc}
\hline Release & Amanda & Kate & Kathleen & Kyle & MaryBeth & Rhonda & Shon & Tyrell & $P$-value \\
\hline R1-CR390 & 41 & 0 & 0 & 0 & 41 & 30 & 0 & 52 & \\
R2-CR346 & 18 & 0 & 0 & 0 & 20 & 15 & 0 & 23 & 0.9994 \\
R3-CR325 & 12 & 0 & 0 & 0 & 14 & 9 & 0 & 15 & \\
R4-CR307 & 13 & 0 & 0 & 0 & 12 & 10 & 0 & 15 & 0.9949 \\
R5-CR275 & 12 & 0 & 0 & 0 & 12 & 10 & 0 & 16 & \\
R6-CR233 & 0 & 10 & 11 & 12 & 0 & 0 & 16 & 0 & 0.9904 \\
R7-CR161 & 0 & 11 & 11 & 11 & 0 & 0 & 17 & 0 & \\
\hline
\end{tabular}

x. Replicate 24

\begin{tabular}{|c|c|c|c|c|c|c|c|c|c|}
\hline Release & Amanda & Kate & Kathleen & Kyle & MaryBeth & Rhonda & Shon & Tyrell & $P$-value \\
\hline R1-CR390 & 40 & 0 & 0 & 0 & 45 & 27 & 0 & 52 & \multirow{3}{*}{0.9923} \\
\hline R2-CR346 & 16 & 0 & 0 & 0 & 22 & 14 & 0 & 23 & \\
\hline R3-CR325 & 12 & 0 & 0 & 0 & 12 & 9 & 0 & 17 & \\
\hline R4-CR307 & 12 & 0 & 0 & 0 & 13 & 8 & 0 & 17 & \multirow{2}{*}{0.9590} \\
\hline R5-CR275 & 11 & 0 & 0 & 0 & 12 & 10 & 0 & 17 & \\
\hline R6-CR233 & 0 & 12 & 13 & 11 & 0 & 0 & 14 & 0 & \multirow{2}{*}{0.9836} \\
\hline R7-CR161 & 0 & 11 & 12 & 12 & 0 & 0 & 15 & 0 & \\
\hline Chi-sq & $\mathrm{re}=491.5$ & & & $\mathrm{FF}=42$ & & & & & $<0.0001$ \\
\hline
\end{tabular}


Table A.2. (contd)

y. Replicate 25

\begin{tabular}{ccccc}
\hline Release & Kate & Kathleen & Kyle & Shon \\
\hline R1-CR390 & 39 & 47 & 36 & 40 \\
R2-CR346 & 16 & 16 & 16 & 26 \\
R3-CR325 & 10 & 13 & 11 & 16 \\
R4-CR307 & 12 & 11 & 10 & 17 \\
R5-CR275 & 10 & 12 & 11 & 17 \\
R6-CR233 & 12 & 12 & 11 & 15 \\
R7-CR161 & 11 & 11 & 11 & 12 \\
\hline Chi-square $=5.3708$ & DF $=18$ & $P$-value $=0.9982$ \\
\hline
\end{tabular}

z. Replicate 26

\begin{tabular}{ccccc}
\hline Release & Kate & Kathleen & Kyle & Shon \\
\hline R1-CR390 & 36 & 38 & 37 & 53 \\
R2-CR346 & 16 & 20 & 16 & 24 \\
R3-CR325 & 11 & 13 & 11 & 15 \\
R4-CR307 & 10 & 13 & 11 & 16 \\
R5-CR275 & 11 & 13 & 11 & 15 \\
R6-CR233 & 11 & 11 & 11 & 16 \\
R7-CR161 & 10 & 10 & 8 & 12 \\
\hline Chi-square $=1.0206$ & DF $=18$ & & $P$-value $=1$ \\
\hline
\end{tabular}

aa. Replicate 27

\begin{tabular}{cccccccccc}
\hline Release & Amanda & Kate & Kathleen & Kyle & MaryBeth & Rhonda & Shon & Tyrell & $P$-value \\
\hline R1-CR390 & 0 & 35 & 40 & 35 & 0 & 0 & 54 & 0 & \\
R2-CR346 & 0 & 18 & 17 & 17 & 0 & 0 & 23 & 0 & 0.9981 \\
R3-CR325 & 0 & 12 & 12 & 11 & 0 & 0 & 15 & 0 & \\
R4-CR307 & 0 & 10 & 10 & 11 & 0 & 0 & 14 & 0 & 0.9924 \\
R5-CR275 & 0 & 10 & 11 & 10 & 0 & 0 & 14 & 0 & \\
R6-CR233 & 12 & 0 & 0 & 0 & 13 & 11 & 0 & 14 & 0.9939 \\
R7-CR161 & 12 & 0 & 0 & 0 & 13 & 10 & 0 & 15 & \\
\hline Chi-square $=480.2391$ & \multicolumn{7}{c}{ DF $=42$} & & \\
\hline
\end{tabular}

bb. Replicate 28

\begin{tabular}{|c|c|c|c|c|c|c|c|c|c|}
\hline Release & Amanda & Kate & Kathleen & Kyle & MaryBeth & Rhonda & Shon & Tyrell & $P$-value \\
\hline R1-CR390 & 0 & 38 & 41 & 39 & 0 & 0 & 46 & 0 & \multirow{3}{*}{0.9984} \\
\hline R2-CR346 & 0 & 16 & 18 & 18 & 0 & 0 & 24 & 0 & \\
\hline R3-CR325 & 0 & 10 & 11 & 10 & 0 & 0 & 14 & 0 & \\
\hline R4-CR307 & 0 & 11 & 11 & 9 & 0 & 0 & 14 & 0 & \multirow{2}{*}{0.9284} \\
\hline R5-CR275 & 0 & 9 & 13 & 10 & 0 & 0 & 13 & 0 & \\
\hline R6-CR233 & 12 & 0 & 0 & 0 & 12 & 9 & 0 & 16 & \multirow{2}{*}{0.8987} \\
\hline R7-CR161 & 10 & 0 & 0 & 0 & 15 & 10 & 0 & 15 & \\
\hline \multicolumn{3}{|c|}{ Chi-square $=478.3536$} & & $\overline{\mathrm{DF}}=42$ & & & & & $<0.0001$ \\
\hline
\end{tabular}


Table A.2. (contd)

cc. Replicate 29

\begin{tabular}{ccccc}
\hline Release & Amanda & MaryBeth & Rhonda & Tyrell \\
\hline R1-CR390 & 37 & 43 & 34 & 50 \\
R2-CR346 & 18 & 18 & 16 & 24 \\
R3-CR325 & 13 & 14 & 8 & 15 \\
R4-CR307 & 12 & 13 & 9 & 16 \\
R5-CR275 & 12 & 12 & 10 & 15 \\
R6-CR233 & 11 & 12 & 10 & 16 \\
R7-CR161 & 12 & 12 & 10 & 16 \\
\hline Chi-square $=1.2964$ & DF $=18$ & & $P$-value $=1$ \\
\hline
\end{tabular}

dd. Replicate 30

\begin{tabular}{ccccc}
\hline Release & Amanda & MaryBeth & Rhonda & Tyrell \\
\hline R1-CR390 & 21 & 21 & 16 & 24 \\
R2-CR346 & 17 & 21 & 16 & 22 \\
R3-CR325 & 12 & 13 & 10 & 15 \\
R4-CR307 & 12 & 12 & 10 & 16 \\
R5-CR275 & 11 & 14 & 10 & 15 \\
R6-CR233 & 12 & 12 & 10 & 16 \\
R7-CR161 & 12 & 13 & 9 & 16 \\
\hline Chi-square $=0.9309$ & DF $=18$ & & $P$-value $=1$ \\
\hline
\end{tabular}

ee. Replicate 31

\begin{tabular}{|c|c|c|c|c|c|c|c|c|c|}
\hline Release & Amanda & Kate & Kathleen & Kyle & MaryBeth & Rhonda & Shon & Tyrell & $P$-value \\
\hline R1-CR390 & 33 & 0 & 0 & 0 & 35 & 26 & 0 & 44 & \multirow{3}{*}{1.0000} \\
\hline R2-CR346 & 14 & 0 & 0 & 0 & 16 & 11 & 0 & 19 & \\
\hline R3-CR325 & 12 & 0 & 0 & 0 & 12 & 10 & 0 & 16 & \\
\hline R4-CR307 & 12 & 0 & 0 & 0 & 13 & 11 & 0 & 19 & \multirow{2}{*}{0.9684} \\
\hline R5-CR275 & 12 & 0 & 0 & 0 & 15 & 11 & 0 & 17 & \\
\hline R6-CR233 & 0 & 13 & 13 & 13 & 0 & 0 & 16 & 0 & \multirow{2}{*}{0.9986} \\
\hline R7-CR161 & 0 & 14 & 15 & 14 & 0 & 0 & 17 & 0 & \\
\hline \multicolumn{3}{|c|}{ Chi-square $=473.8784$} & & $\mathrm{DF}=42$ & & & & & $<0.0001$ \\
\hline
\end{tabular}

ff. Replicate 32

\begin{tabular}{|c|c|c|c|c|c|c|c|c|c|}
\hline Release & Amanda & Kate & Kathleen & Kyle & MaryBeth & Rhonda & Shon & Tyrell & $P$-value \\
\hline R1-CR390 & 33 & 0 & 0 & 0 & 39 & 28 & 0 & 40 & \multirow{3}{*}{0.9976} \\
\hline R2-CR346 & 15 & 0 & 0 & 0 & 17 & 13 & 0 & 20 & \\
\hline R3-CR325 & 13 & 0 & 0 & 0 & 13 & 11 & 0 & 18 & \\
\hline R4-CR307 & 12 & 0 & 0 & 0 & 14 & 11 & 0 & 18 & \multirow{2}{*}{0.9925} \\
\hline R5-CR275 & 13 & 0 & 0 & 0 & 14 & 13 & 0 & 20 & \\
\hline R6-CR233 & 0 & 12 & 12 & 11 & 0 & 0 & 15 & 0 & \multirow{2}{*}{0.9958} \\
\hline R7-CR161 & 0 & 15 & 14 & 14 & 0 & 0 & 17 & 0 & \\
\hline Chi-squ & $\mathrm{re}=486.7$ & & & $\mathrm{DF}=42$ & & & & & $<0.0001$ \\
\hline
\end{tabular}


Table A.3. Estimates of reach survival and cumulative survival for (a) yearling Chinook salmon smolts and (b) steelhead, along with $P$-values associated with the $F$-tests of homogeneous survival across fish tagged by different staff members.

a. Yearling Chinook salmon smolts

1) Release 1 - Reach survival

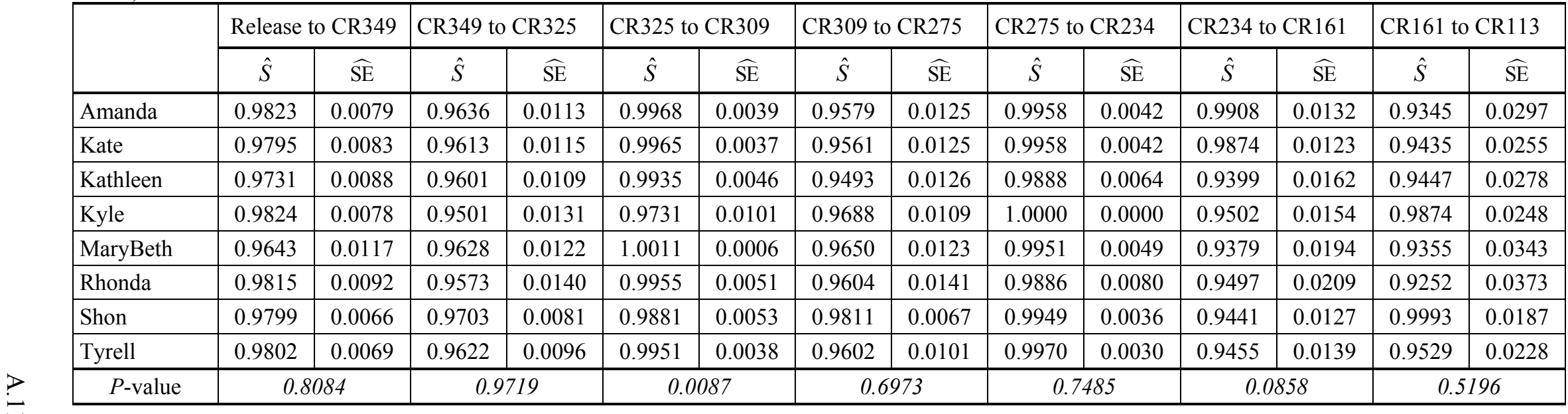

2) Release 1 - Cumulative survival

\begin{tabular}{|c|c|c|c|c|c|c|c|c|c|c|c|c|c|c|}
\hline & \multicolumn{2}{|c|}{ Release to CR349 } & \multicolumn{2}{|c|}{ Release to CR325 } & \multicolumn{2}{|c|}{ Release to CR309 } & \multicolumn{2}{|c|}{ Release to CR275 } & \multicolumn{2}{|c|}{ Release to CR234 } & \multicolumn{2}{|c|}{ Release to CR161 } & \multicolumn{2}{|c|}{ Release to CR113 } \\
\hline & $\overline{\hat{S}}$ & $\widehat{\mathrm{SE}}$ & $\overline{\hat{S}}$ & $\widehat{\mathrm{SE}}$ & $\overline{\hat{S}}$ & $\widehat{\mathrm{SE}}$ & $\overline{\hat{S}}$ & $\widehat{\mathrm{SE}}$ & $\overline{\hat{S}}$ & $\widehat{\widehat{\mathrm{SE}}}$ & $\overline{\hat{S}}$ & $\widehat{\mathrm{SE}}$ & $\overline{\hat{S}}$ & $\widehat{\mathrm{SE}}$ \\
\hline Amanda & 0.9823 & 0.0079 & 0.9465 & 0.0135 & 0.9435 & 0.0139 & 0.9038 & 0.0176 & 0.9000 & 0.0179 & 0.8917 & 0.0213 & 0.8332 & 0.0301 \\
\hline Kate & 0.9795 & 0.0083 & 0.9416 & 0.0138 & 0.9382 & 0.0141 & 0.8970 & 0.0179 & 0.8932 & 0.0181 & 0.8820 & 0.0210 & 0.8321 & 0.0275 \\
\hline Kathleen & 0.9731 & 0.0088 & 0.9343 & 0.0136 & 0.9282 & 0.0141 & 0.8812 & 0.0178 & 0.8713 & 0.0183 & 0.8190 & 0.0223 & 0.7737 & 0.0296 \\
\hline Kyle & 0.9824 & 0.0078 & 0.9334 & 0.0149 & 0.9083 & 0.0172 & 0.8799 & 0.0193 & 0.8799 & 0.0193 & 0.8361 & 0.0228 & 0.8255 & 0.0296 \\
\hline MaryBeth & 0.9643 & 0.0117 & 0.9284 & 0.0163 & 0.9294 & 0.0163 & 0.8969 & 0.0192 & 0.8926 & 0.0195 & 0.8371 & 0.0252 & 0.7831 & 0.0351 \\
\hline Rhonda & 0.9815 & 0.0092 & 0.9395 & 0.0163 & 0.9353 & 0.0169 & 0.8983 & 0.0208 & 0.8880 & 0.0215 & 0.8433 & 0.0276 & 0.7802 & 0.0374 \\
\hline Shon & 0.9799 & 0.0066 & 0.9508 & 0.0102 & 0.9395 & 0.0113 & 0.9218 & 0.0127 & 0.9171 & 0.0131 & 0.8658 & 0.0170 & 0.8652 & 0.0223 \\
\hline Tyrell & 0.9802 & 0.0069 & 0.9431 & 0.0115 & 0.9385 & 0.0120 & 0.9012 & 0.0149 & 0.8985 & 0.0150 & 0.8496 & 0.0189 & 0.8096 & 0.0251 \\
\hline$P$-value & \multicolumn{2}{|c|}{$\frac{1}{0.8084}$} & \multicolumn{2}{|c|}{0.9613} & \multicolumn{2}{|c|}{0.7767} & \multicolumn{2}{|c|}{0.7912} & \multicolumn{2}{|c|}{0.7700} & \multicolumn{2}{|c|}{0.2749} & \multicolumn{2}{|c|}{0.3320} \\
\hline
\end{tabular}


Table A.3. (contd)

3) Release 2 - Reach survival

\begin{tabular}{|c|c|c|c|c|c|c|c|c|c|c|c|c|}
\hline & \multicolumn{2}{|c|}{ Release to CR325 } & \multicolumn{2}{|c|}{ CR325 to CR309 } & \multicolumn{2}{|c|}{ CR309 to CR275 } & \multicolumn{2}{|c|}{ CR275 to CR234 } & \multicolumn{2}{|c|}{ CR234 to CR161 } & \multicolumn{2}{|c|}{ CR161 to CR113 } \\
\hline & $\hat{S}$ & $\widehat{\mathrm{SE}}$ & $\hat{S}$ & $\widehat{\mathrm{SE}}$ & $\hat{S}$ & $\widehat{\mathrm{SE}}$ & $\hat{S}$ & $\widehat{\mathrm{SE}}$ & $\hat{S}$ & $\widehat{\mathrm{SE}}$ & $\hat{S}$ & $\widehat{\mathrm{SE}}$ \\
\hline Amanda & 1.0005 & 0.0004 & 0.9853 & 0.0106 & 0.9474 & 0.0194 & 1.0000 & 0.0000 & 0.9568 & 0.0211 & 0.9785 & 0.0364 \\
\hline Kate & 1.0000 & 0.0000 & 1.0000 & 0.0000 & 0.9616 & 0.0173 & 0.9908 & 0.0091 & 0.9540 & 0.0243 & 0.9583 & 0.0450 \\
\hline Kathleen & 1.0001 & 0.0001 & 0.9931 & 0.0069 & 0.9046 & 0.0244 & 0.9919 & 0.0080 & 0.9154 & 0.0274 & 0.9372 & 0.0382 \\
\hline Kyle & 0.9932 & 0.0075 & 0.9690 & 0.0153 & 0.9459 & 0.0201 & 0.9911 & 0.0089 & 0.9676 & 0.0191 & 1.0046 & 0.0362 \\
\hline MaryBeth & 0.9879 & 0.0095 & 0.9783 & 0.0124 & 0.9731 & 0.0137 & 0.9919 & 0.0080 & 0.9643 & 0.0219 & 0.9551 & 0.0370 \\
\hline Rhonda & 0.9827 & 0.0124 & 0.9908 & 0.0094 & 0.9725 & 0.0157 & 1.0000 & 0.0000 & 0.9351 & 0.0285 & 0.9268 & 0.0414 \\
\hline Shon & 0.9746 & 0.0112 & 1.0002 & 0.0002 & 0.9690 & 0.0126 & 0.9942 & 0.0058 & 0.9585 & 0.0174 & 0.9448 & 0.0325 \\
\hline Tyrell & 0.9898 & 0.0074 & 0.9895 & 0.0076 & 0.9523 & 0.0158 & 0.9937 & 0.0063 & 0.9546 & 0.0219 & 0.9101 & 0.0350 \\
\hline$P$-value & \multicolumn{2}{|c|}{0.2701} & \multicolumn{2}{|c|}{0.3361} & \multicolumn{2}{|c|}{0.1281} & \multicolumn{2}{|c|}{0.9480} & \multicolumn{2}{|c|}{0.7861} & \multicolumn{2}{|c|}{0.7442} \\
\hline
\end{tabular}

4) Release 2 - Cumulative survival

\begin{tabular}{|c|c|c|c|c|c|c|c|c|c|c|c|c|}
\hline & \multicolumn{2}{|c|}{ Release to CR325 } & \multicolumn{2}{|c|}{ Release to CR309 } & \multicolumn{2}{|c|}{ Release to CR275 } & \multicolumn{2}{|c|}{ Release to CR234 } & \multicolumn{2}{|c|}{ Release to CR161 } & \multicolumn{2}{|c|}{ Release to CR113 } \\
\hline & $\hat{S}$ & $\widehat{\mathrm{SE}}$ & $\hat{S}$ & $\widehat{\mathrm{SE}}$ & $\hat{S}$ & $\widehat{\mathrm{SE}}$ & $\hat{S}$ & $\widehat{\mathrm{SE}}$ & $\hat{S}$ & $\widehat{\mathrm{SE}}$ & $\hat{S}$ & $\widehat{\mathrm{SE}}$ \\
\hline Amanda & 1.0005 & 0.0004 & 0.9857 & 0.0103 & 0.9338 & 0.0213 & 0.9338 & 0.0213 & 0.8935 & 0.0284 & 0.8743 & 0.0403 \\
\hline Kate & 1.0000 & 0.0000 & 1.0000 & 0.0000 & 0.9616 & 0.0173 & 0.9528 & 0.0188 & 0.9089 & 0.0293 & 0.8710 & 0.0457 \\
\hline Kathleen & 1.0001 & 0.0001 & 0.9932 & 0.0068 & 0.8984 & 0.0250 & 0.8912 & 0.0257 & 0.8158 & 0.0339 & 0.7646 & 0.0420 \\
\hline Kyle & 0.9932 & 0.0075 & 0.9624 & 0.0165 & 0.9104 & 0.0249 & 0.9023 & 0.0258 & 0.8730 & 0.0303 & 0.8770 & 0.0419 \\
\hline MaryBeth & 0.9879 & 0.0095 & 0.9664 & 0.0148 & 0.9405 & 0.0196 & 0.9329 & 0.0205 & 0.8996 & 0.0284 & 0.8592 & 0.0384 \\
\hline Rhonda & 0.9827 & 0.0124 & 0.9737 & 0.0151 & 0.9469 & 0.0211 & 0.9469 & 0.0211 & 0.8854 & 0.0334 & 0.8206 & 0.0439 \\
\hline Shon & 0.9746 & 0.0112 & 0.9748 & 0.0112 & 0.9445 & 0.0164 & 0.9391 & 0.0170 & 0.9001 & 0.0231 & 0.8504 & 0.0345 \\
\hline Tyrell & 0.9898 & 0.0074 & 0.9793 & 0.0104 & 0.9326 & 0.0182 & 0.9267 & 0.0189 & 0.8846 & 0.0271 & 0.8050 & 0.0352 \\
\hline$P$-value & \multicolumn{2}{|c|}{0.2701} & \multicolumn{2}{|c|}{0.3867} & \multicolumn{2}{|c|}{0.4513} & \multicolumn{2}{|c|}{0.4331} & \multicolumn{2}{|c|}{0.4395} & \multicolumn{2}{|c|}{0.4395} \\
\hline
\end{tabular}


Table A.3. (contd)

5) Release 3 - Reach survival

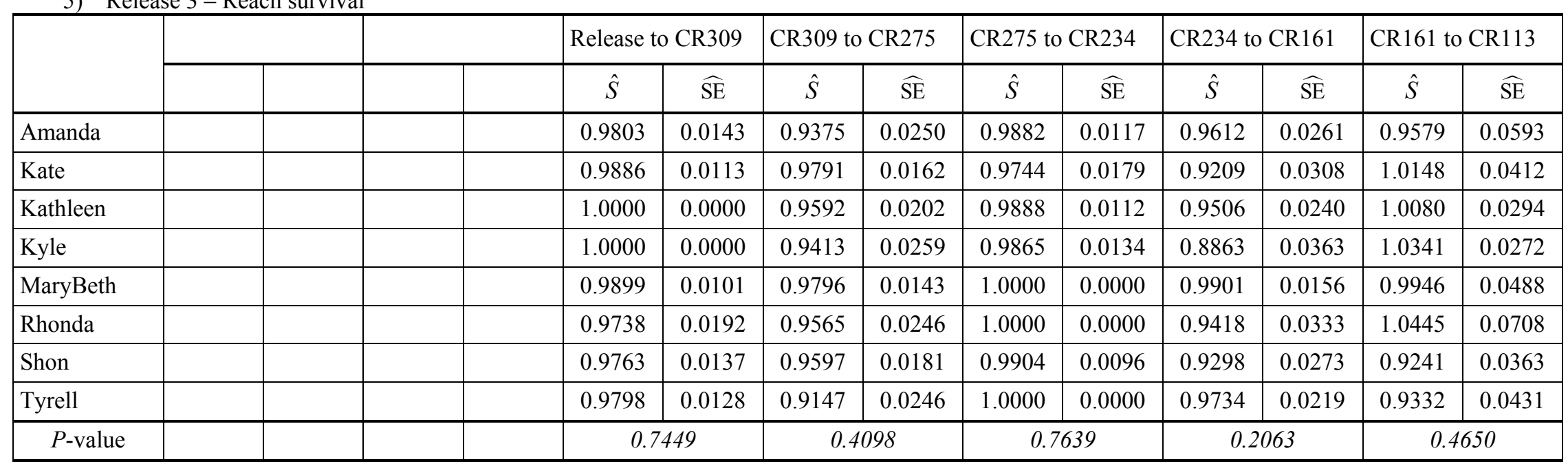

6) Release 3 - Cumulative survival

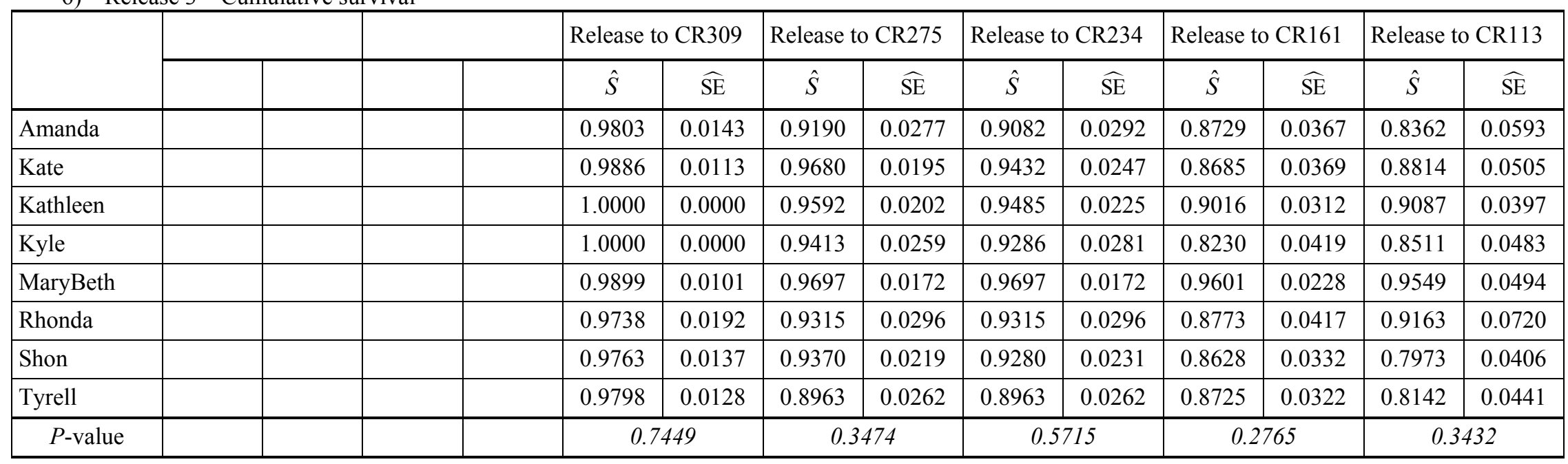


Table A.3. (contd)

7) Release 4 - Reach survival

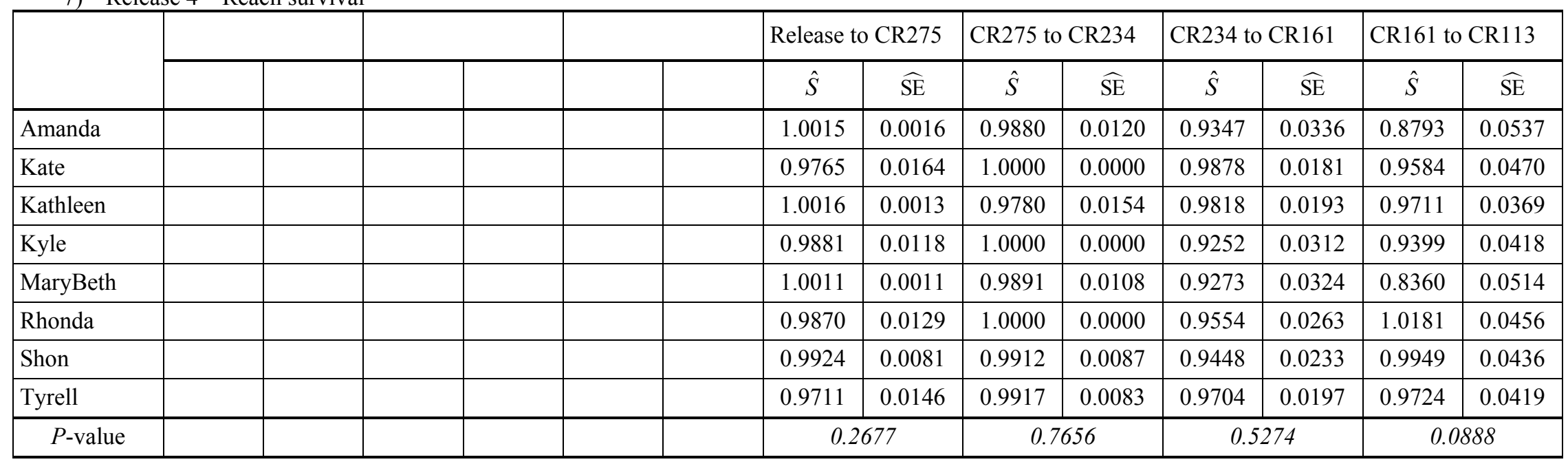

8) Release 4-Cumulative survival

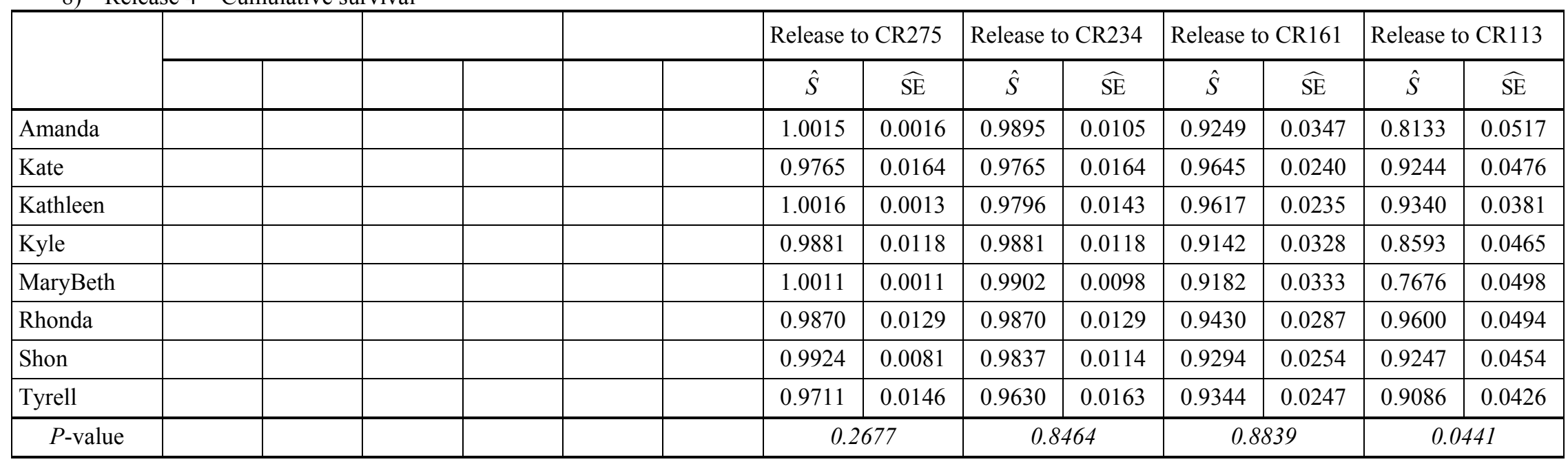


Table A.3. (contd)

9) Release 5 - Reach survival

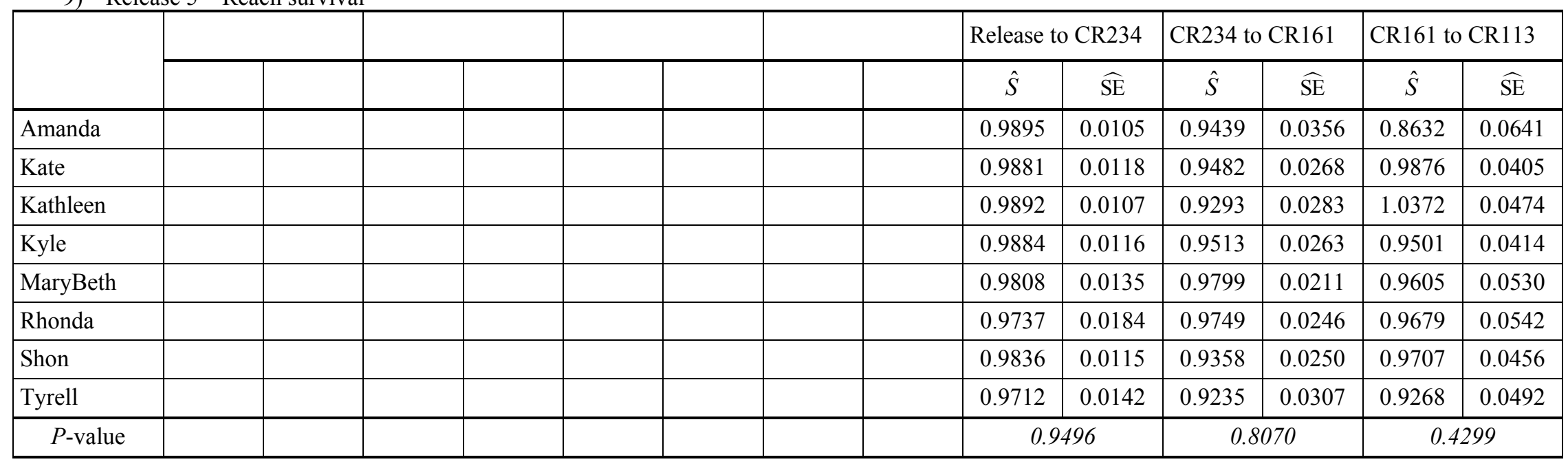

10) Release 5 -Cumulative survival

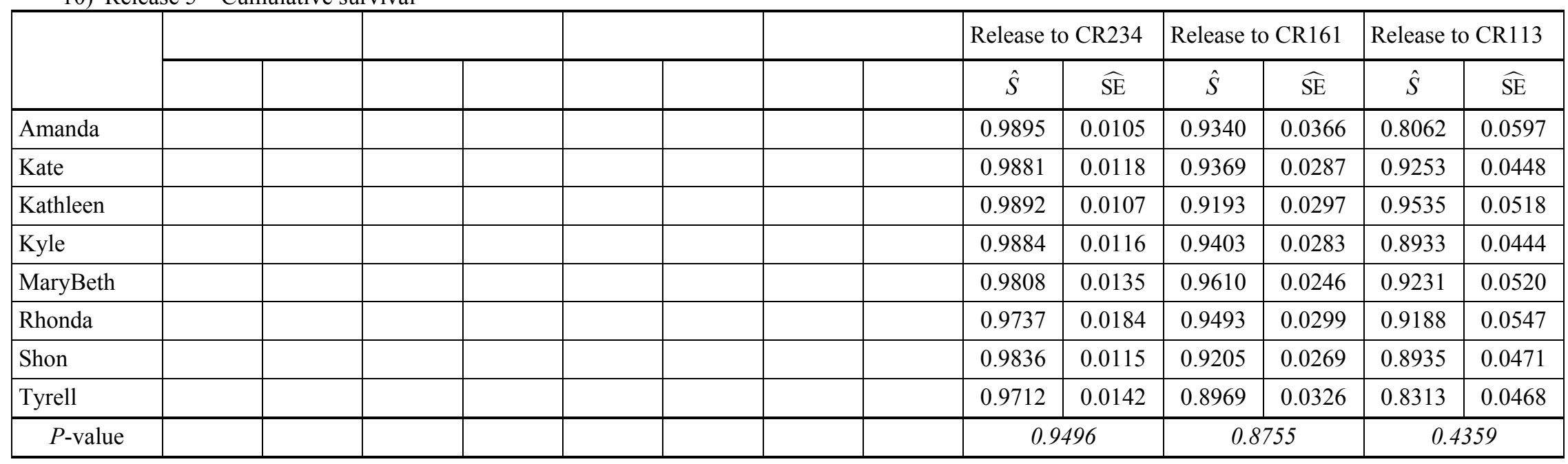


Table A.3. (contd)

11) Release 6-Reach survival

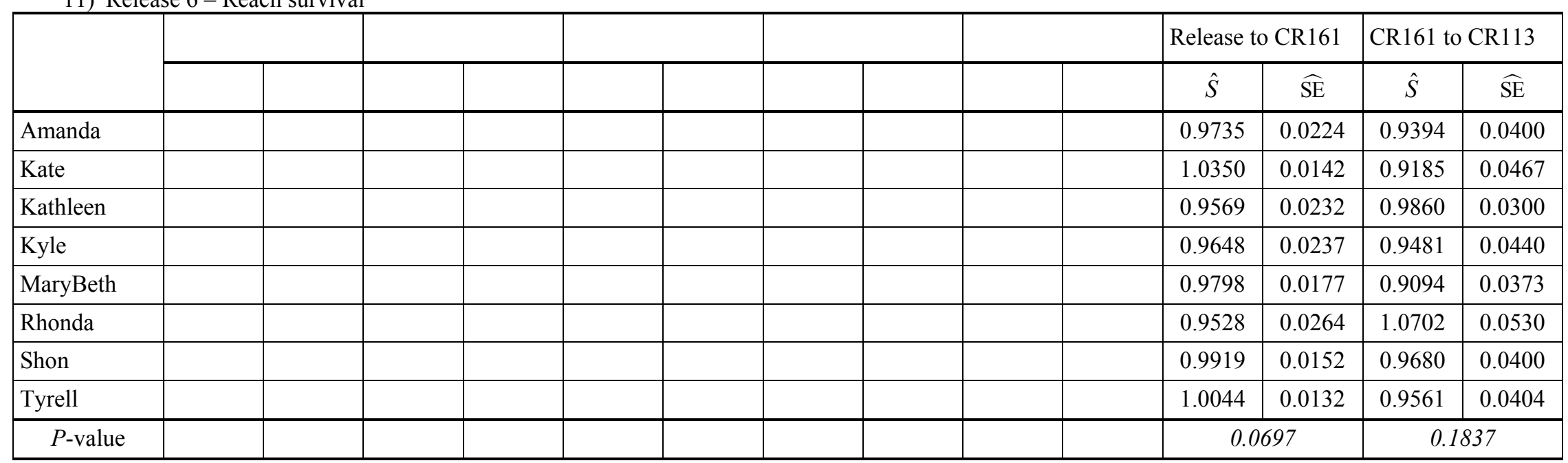

12) Release 6 -Cumulative survival

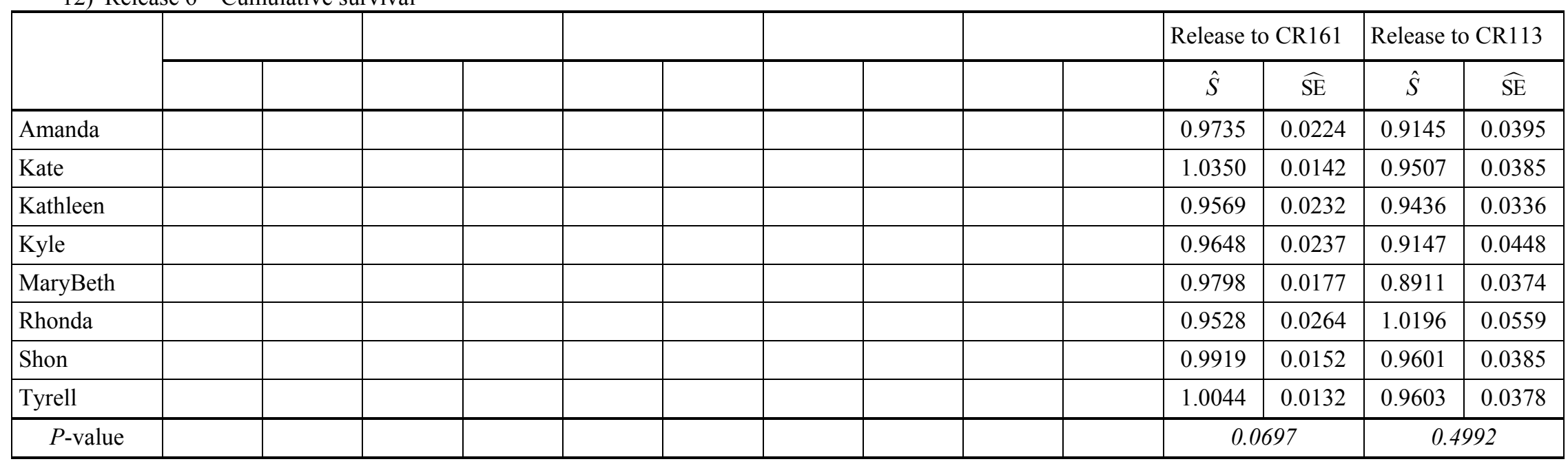


Table A.3. (contd)

13) Release 7 - Reach survival

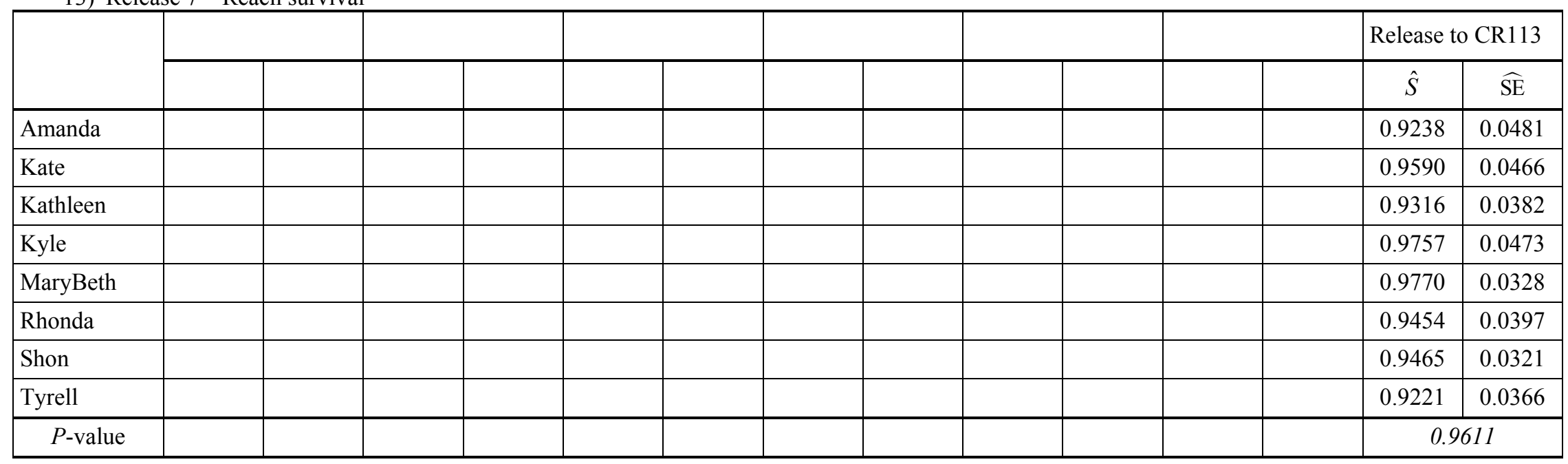


Table A.3. (contd)

b. Steelhead salmon smolts

14) Release 1 - Reach survival

\begin{tabular}{|c|c|c|c|c|c|c|c|c|c|c|c|c|c|c|}
\hline & \multicolumn{2}{|c|}{ Release to CR349 } & \multicolumn{2}{|c|}{ CR349 to CR325 } & \multicolumn{2}{|c|}{ CR325 to CR309 } & \multicolumn{2}{|c|}{ CR309 to CR275 } & \multicolumn{2}{|c|}{ CR275 to CR234 } & \multicolumn{2}{|c|}{ CR234 to CR161 } & \multicolumn{2}{|c|}{ CR161 to CR113 } \\
\hline & $\hat{S}$ & $\widehat{\mathrm{SE}}$ & $\hat{S}$ & $\widehat{\mathrm{SE}}$ & $\hat{S}$ & $\widehat{\mathrm{SE}}$ & $\hat{S}$ & $\widehat{\mathrm{SE}}$ & $\hat{S}$ & $\widehat{\mathrm{SE}}$ & $\hat{S}$ & $\widehat{\mathrm{SE}}$ & $\hat{S}$ & $\widehat{\mathrm{SE}}$ \\
\hline Amanda & 0.9601 & 0.0113 & 0.9860 & 0.0070 & 0.9934 & 0.0051 & 0.9768 & 0.0098 & 0.9826 & 0.0086 & 0.9573 & 0.0150 & 0.8991 & 0.0293 \\
\hline Kate & 0.9508 & 0.0128 & 0.9814 & 0.0083 & 0.9962 & 0.0039 & 0.9849 & 0.0086 & 0.9651 & 0.0121 & 0.9382 & 0.0159 & 1.0187 & 0.0308 \\
\hline Kathleen & 0.9369 & 0.0133 & 0.9873 & 0.0064 & 0.9901 & 0.0057 & 0.9683 & 0.0102 & 0.9887 & 0.0065 & 0.9645 & 0.0129 & 1.0048 & 0.0323 \\
\hline Kyle & 0.9686 & 0.0104 & 0.9601 & 0.0118 & 0.9886 & 0.0065 & 0.9781 & 0.0093 & 0.9872 & 0.0073 & 0.9612 & 0.0140 & 0.9568 & 0.0304 \\
\hline MaryBeth & 0.9783 & 0.0088 & 0.9634 & 0.0115 & 0.9882 & 0.0069 & 0.9829 & 0.0088 & 0.9817 & 0.0091 & 0.9491 & 0.0178 & 0.9302 & 0.0380 \\
\hline Rhonda & 0.9584 & 0.0129 & 0.9739 & 0.0106 & 0.9955 & 0.0046 & 0.9972 & 0.0047 & 0.9892 & 0.0076 & 0.9270 & 0.0190 & 0.9763 & 0.0341 \\
\hline Shon & 0.9515 & 0.0101 & 0.9696 & 0.0083 & 0.9952 & 0.0034 & 0.9819 & 0.0068 & 0.9840 & 0.0065 & 0.9368 & 0.0129 & 1.0022 & 0.0231 \\
\hline Tyrell & 0.9736 & 0.0079 & 0.9778 & 0.0073 & 0.9954 & 0.0036 & 0.9688 & 0.0092 & 0.9818 & 0.0074 & 0.9495 & 0.0131 & 0.9490 & 0.0285 \\
\hline$P$-value & \multicolumn{2}{|c|}{0.1645} & \multicolumn{2}{|c|}{0.2884} & \multicolumn{2}{|c|}{0.8869} & \multicolumn{2}{|c|}{0.3137} & \multicolumn{2}{|c|}{0.5454} & \multicolumn{2}{|c|}{0.6392} & \multicolumn{2}{|c|}{0.0930} \\
\hline
\end{tabular}

15) Release 1 - Cumulative survival

\begin{tabular}{|c|c|c|c|c|c|c|c|c|c|c|c|c|c|c|}
\hline & \multicolumn{2}{|c|}{ Release to CR349 } & \multicolumn{2}{|c|}{ Release to CR325 } & \multicolumn{2}{|c|}{ Release to CR309 } & \multicolumn{2}{|c|}{ Release to CR275 } & \multicolumn{2}{|c|}{ Release to CR234 } & \multicolumn{2}{|c|}{ Release to CR161 } & \multicolumn{2}{|c|}{ Release to CR113 } \\
\hline & $\hat{S}$ & $\widehat{\mathrm{SE}}$ & $\hat{S}$ & $\widehat{\mathrm{SE}}$ & $\hat{S}$ & $\widehat{\mathrm{SE}}$ & $\hat{S}$ & $\widehat{\mathrm{SE}}$ & $\hat{S}$ & $\widehat{\mathrm{SE}}$ & $\hat{S}$ & $\widehat{\mathrm{SE}}$ & $\hat{S}$ & $\widehat{\mathrm{SE}}$ \\
\hline Amanda & 0.9601 & 0.0113 & 0.9467 & 0.0130 & 0.9405 & 0.0138 & 0.9186 & 0.0161 & 0.9027 & 0.0172 & 0.8641 & 0.0213 & 0.7769 & 0.0302 \\
\hline Kate & 0.9508 & 0.0128 & 0.9331 & 0.0148 & 0.9296 & 0.0152 & 0.9155 & 0.0170 & 0.8836 & 0.0191 & 0.8289 & 0.0227 & 0.8444 & 0.0341 \\
\hline Kathleen & 0.9369 & 0.0133 & 0.9251 & 0.0144 & 0.9159 & 0.0152 & 0.8869 & 0.0175 & 0.8769 & 0.0180 & 0.8458 & 0.0207 & 0.8499 & 0.0333 \\
\hline Kyle & 0.9686 & 0.0104 & 0.9299 & 0.0151 & 0.9193 & 0.0161 & 0.8992 & 0.0179 & 0.8877 & 0.0187 & 0.8533 & 0.0218 & 0.8164 & 0.0323 \\
\hline MaryBeth & 0.9783 & 0.0088 & 0.9424 & 0.0141 & 0.9313 & 0.0152 & 0.9153 & 0.0170 & 0.8986 & 0.0182 & 0.8528 & 0.0235 & 0.7933 & 0.0369 \\
\hline Rhonda & 0.9584 & 0.0129 & 0.9334 & 0.0161 & 0.9292 & 0.0166 & 0.9266 & 0.0171 & 0.9167 & 0.0178 & 0.8497 & 0.0240 & 0.8296 & 0.0362 \\
\hline Shon & 0.9515 & 0.0101 & 0.9225 & 0.0126 & 0.9181 & 0.0129 & 0.9015 & 0.0141 & 0.8870 & 0.0149 & 0.8310 & 0.0181 & 0.8328 & 0.0259 \\
\hline Tyrell & 0.9736 & 0.0079 & 0.9519 & 0.0105 & 0.9476 & 0.0110 & 0.9180 & 0.0137 & 0.9013 & 0.0146 & 0.8557 & 0.0183 & 0.8121 & 0.0289 \\
\hline$P$-value & \multicolumn{2}{|c|}{0.1645} & \multicolumn{2}{|c|}{0.7891} & \multicolumn{2}{|c|}{0.7715} & \multicolumn{2}{|c|}{0.7262} & \multicolumn{2}{|c|}{0.8003} & \multicolumn{2}{|c|}{0.9448} & \multicolumn{2}{|c|}{0.7588} \\
\hline
\end{tabular}


Table A.3. (contd)

16) Release 2 - Reach survival

\begin{tabular}{|c|c|c|c|c|c|c|c|c|c|c|c|c|}
\hline & \multicolumn{2}{|c|}{ Release to CR325 } & \multicolumn{2}{|c|}{ CR325 to CR309 } & \multicolumn{2}{|c|}{ CR309 to CR275 } & \multicolumn{2}{|c|}{ CR275 to CR234 } & \multicolumn{2}{|c|}{ CR234 to CR161 } & \multicolumn{2}{|c|}{ CR161 to CR113 } \\
\hline & $\hat{S}$ & $\widehat{\mathrm{SE}}$ & $\hat{S}$ & $\widehat{\mathrm{SE}}$ & $\hat{S}$ & $\widehat{\mathrm{SE}}$ & $\hat{S}$ & $\widehat{\mathrm{SE}}$ & $\hat{S}$ & $\widehat{\mathrm{SE}}$ & $\hat{S}$ & $\widehat{\mathrm{SE}}$ \\
\hline Amanda & 1.0003 & 0.0003 & 0.9930 & 0.0072 & 0.9726 & 0.0140 & 0.9918 & 0.0082 & 0.9640 & 0.0180 & 0.9567 & 0.0359 \\
\hline Kate & 1.0003 & 0.0003 & 0.9840 & 0.0112 & 0.9780 & 0.0138 & 0.9735 & 0.0151 & 0.9147 & 0.0270 & 0.9356 & 0.0464 \\
\hline Kathleen & 0.9940 & 0.0064 & 0.9671 & 0.0145 & 0.9814 & 0.0116 & 0.9847 & 0.0107 & 0.9642 & 0.0170 & 1.0251 & 0.0483 \\
\hline Kyle & 0.9927 & 0.0077 & 0.9841 & 0.0111 & 0.9868 & 0.0112 & 0.9735 & 0.0151 & 0.9184 & 0.0283 & 0.8859 & 0.0446 \\
\hline MaryBeth & 1.0001 & 0.0001 & 0.9860 & 0.0098 & 0.9718 & 0.0139 & 1.0000 & 0.0000 & 0.9377 & 0.0227 & 0.9253 & 0.0386 \\
\hline Rhonda & 0.9916 & 0.0087 & 0.9908 & 0.0091 & 0.9732 & 0.0153 & 1.0000 & 0.0000 & 0.9456 & 0.0245 & 0.9540 & 0.0556 \\
\hline Shon & 0.9897 & 0.0074 & 0.9892 & 0.0076 & 0.9951 & 0.0054 & 0.9942 & 0.0058 & 0.9082 & 0.0220 & 0.9816 & 0.0336 \\
\hline Tyrell & 0.9952 & 0.0052 & 0.9839 & 0.0092 & 0.9532 & 0.0156 & 0.9933 & 0.0066 & 0.9433 & 0.0206 & 0.9399 & 0.0453 \\
\hline$P$-value & \multicolumn{2}{|c|}{0.7902} & \multicolumn{2}{|c|}{0.7547} & \multicolumn{2}{|c|}{0.4981} & \multicolumn{2}{|c|}{0.4474} & \multicolumn{2}{|c|}{0.5105} & \multicolumn{2}{|c|}{$\frac{1}{0.5348}$} \\
\hline
\end{tabular}

17) Release 2 -Cumulative survival

\begin{tabular}{|c|c|c|c|c|c|c|c|c|c|c|c|c|}
\hline & \multicolumn{2}{|c|}{ Release to CR325 } & \multicolumn{2}{|c|}{ Release to CR309 } & \multicolumn{2}{|c|}{ Release to CR275 } & \multicolumn{2}{|c|}{ Release to CR234 } & \multicolumn{2}{|c|}{ Release to CR161 } & \multicolumn{2}{|c|}{ Release to CR113 } \\
\hline & $\hat{S}$ & $\widehat{\mathrm{SE}}$ & $\hat{S}$ & $\widehat{\mathrm{SE}}$ & $\hat{S}$ & $\widehat{\mathrm{SE}}$ & $\hat{S}$ & $\widehat{\mathrm{SE}}$ & $\hat{S}$ & $\widehat{\mathrm{SE}}$ & $\hat{S}$ & $\widehat{\mathrm{SE}}$ \\
\hline Amanda & 1.0003 & 0.0003 & 0.9932 & 0.0070 & 0.9660 & 0.0154 & 0.9580 & 0.0168 & 0.9236 & 0.0236 & 0.8836 & 0.0386 \\
\hline Kate & 1.0003 & 0.0003 & 0.9843 & 0.0110 & 0.9626 & 0.0173 & 0.9370 & 0.0216 & 0.8571 & 0.0321 & 0.8019 & 0.0487 \\
\hline Kathleen & 0.9940 & 0.0064 & 0.9613 & 0.0155 & 0.9434 & 0.0188 & 0.9290 & 0.0206 & 0.8957 & 0.0254 & 0.9182 & 0.0496 \\
\hline Kyle & 0.9927 & 0.0077 & 0.9769 & 0.0132 & 0.9641 & 0.0170 & 0.9385 & 0.0211 & 0.8619 & 0.0329 & 0.7635 & 0.0455 \\
\hline MaryBeth & 1.0001 & 0.0001 & 0.9861 & 0.0098 & 0.9583 & 0.0167 & 0.9583 & 0.0167 & 0.8986 & 0.0268 & 0.8315 & 0.0409 \\
\hline Rhonda & 0.9916 & 0.0087 & 0.9825 & 0.0123 & 0.9561 & 0.0192 & 0.9561 & 0.0192 & 0.9041 & 0.0296 & 0.8625 & 0.0559 \\
\hline Shon & 0.9897 & 0.0074 & 0.9791 & 0.0104 & 0.9743 & 0.0116 & 0.9686 & 0.0126 & 0.8797 & 0.0242 & 0.8634 & 0.0371 \\
\hline Tyrell & 0.9952 & 0.0052 & 0.9792 & 0.0103 & 0.9333 & 0.0182 & 0.9271 & 0.0188 & 0.8745 & 0.0260 & 0.8220 & 0.0445 \\
\hline$P$-value & \multicolumn{2}{|c|}{0.7902} & \multicolumn{2}{|c|}{0.7126} & \multicolumn{2}{|c|}{0.7533} & \multicolumn{2}{|c|}{0.6753} & \multicolumn{2}{|c|}{0.7042} & \multicolumn{2}{|c|}{0.3265} \\
\hline
\end{tabular}


Table A.3. (contd)

18) Release 3 - Reach survival

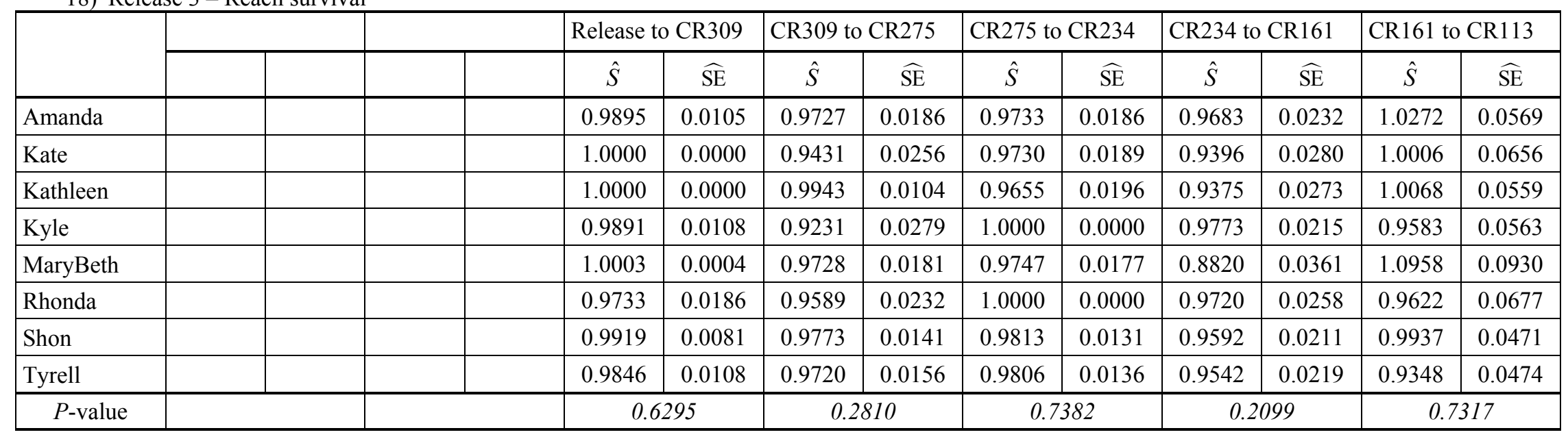

19) Release 3 -Cumulative survival

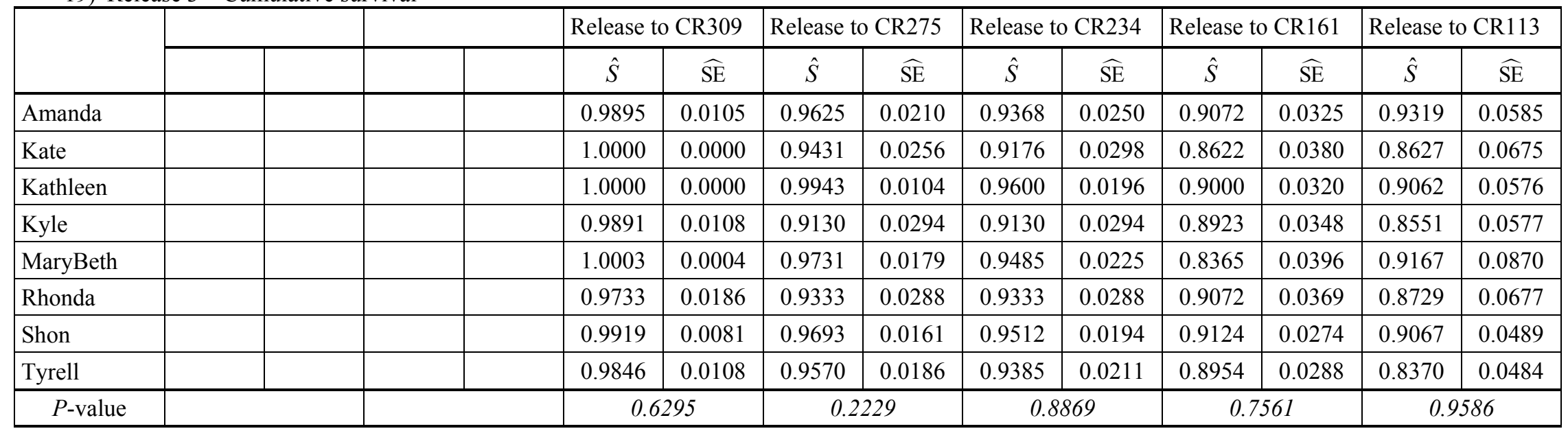


Table A.3. (contd)

20) Release 4 - Reach survival

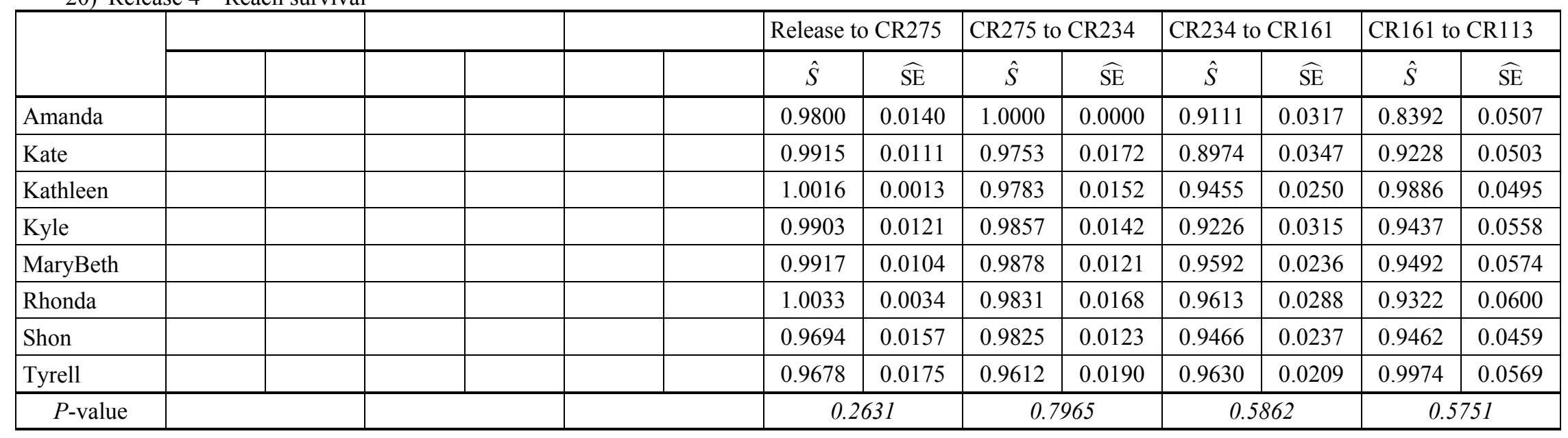

21) Release 4-Cumulative survival

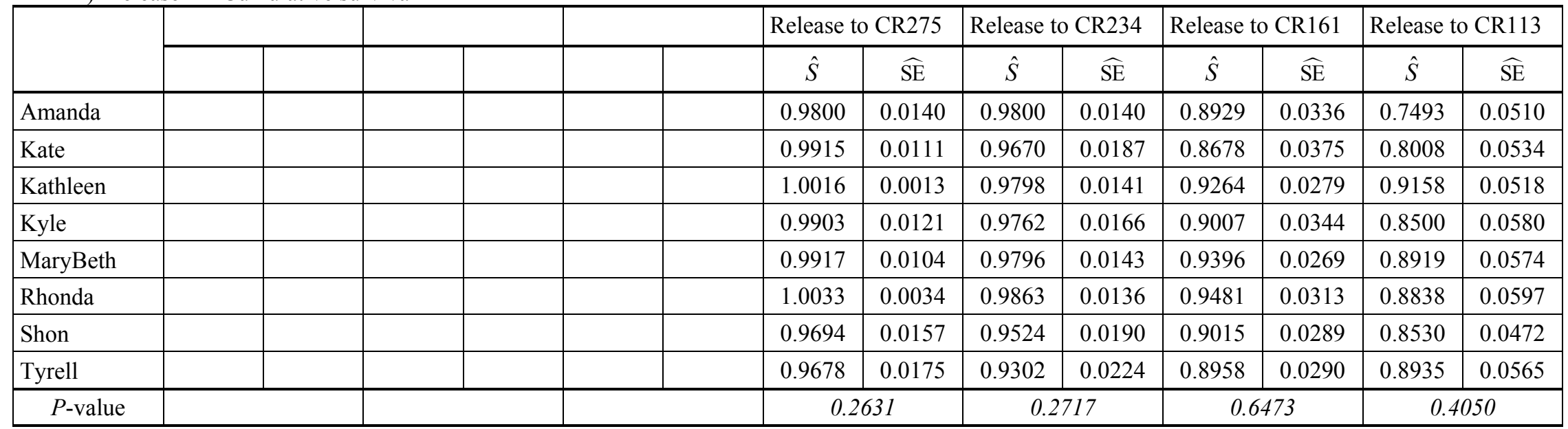


Table A.3. (contd)

22) Release 5-Reach survival

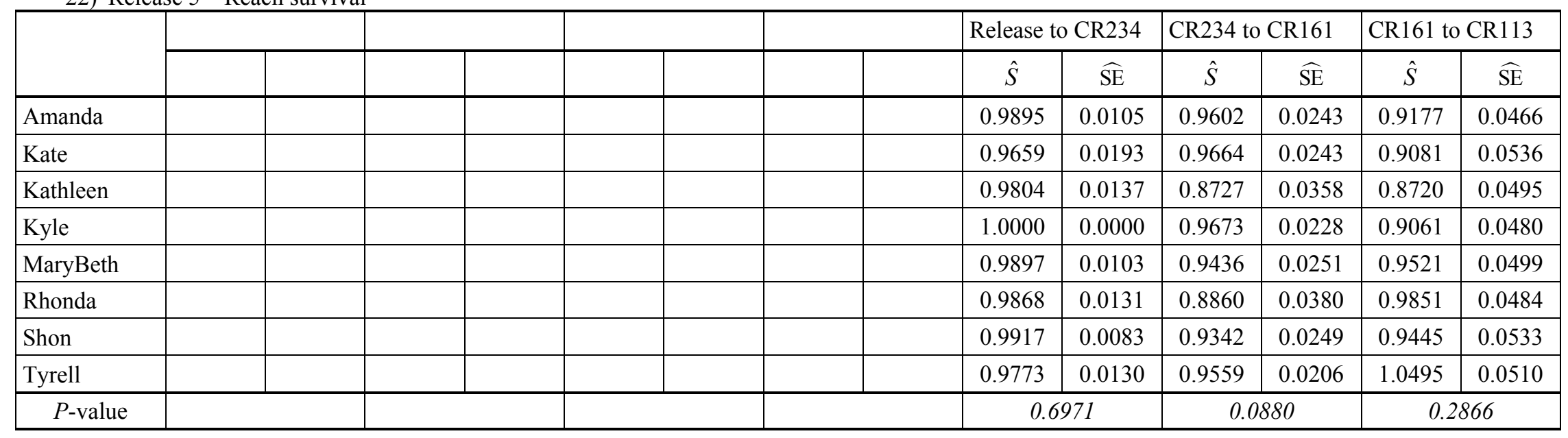

23) Release 5-Cumulative survival

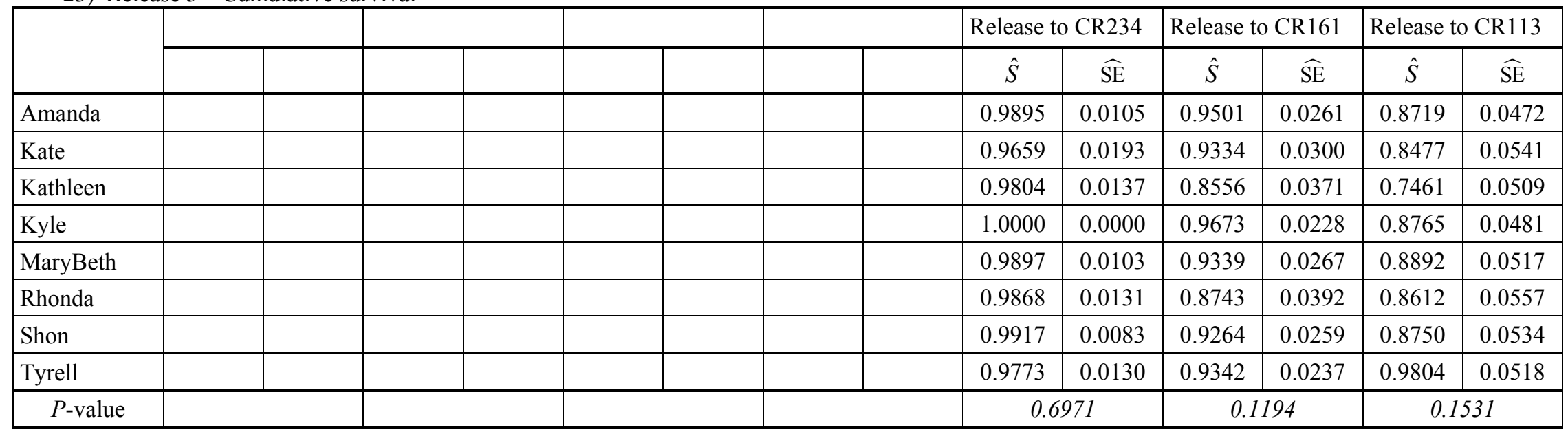


Table A.3. (contd)

24) Release 6-Reach survival

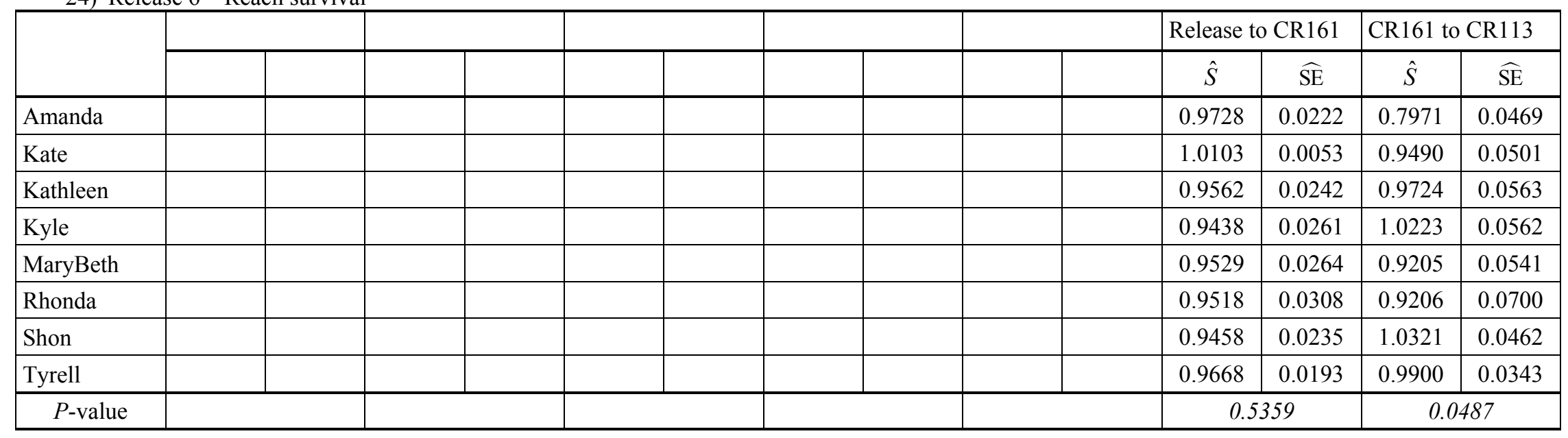

25) Release 6-Cumulative survival

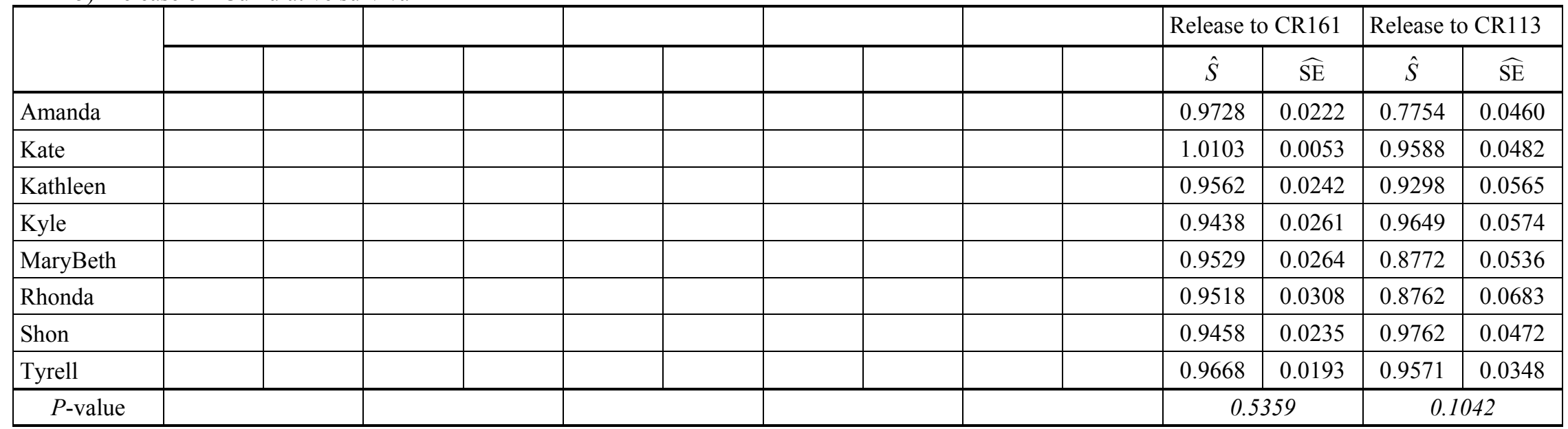


Table A.3. (contd)

26) Release 7 - Reach survival

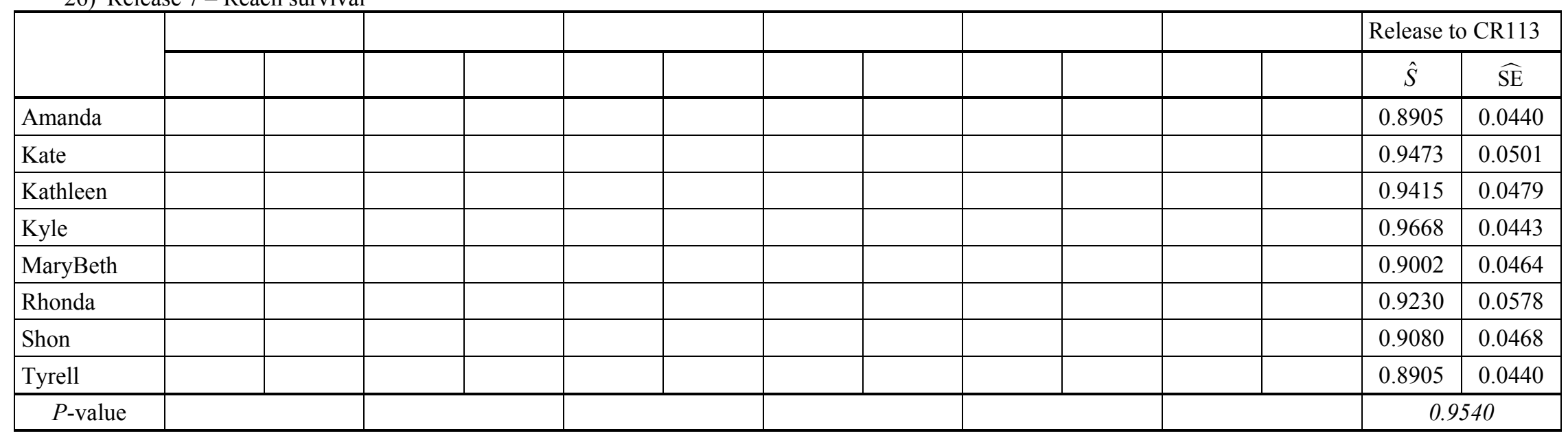




\section{A.2 Examination of Tag-Lot Effects}

Three different tag lots were used in the tagging of the yearling Chinook salmon and steelhead smolts. Overall, the tag lots were not evenly distributed among the seven release locations (Table A.4). However, closer examination found the below-dam release pairs (i.e., $R_{2}-R_{3}, R_{4}-R_{5}$, and $R_{6}-R_{7}$ ) to be homogeneous with regard to tag-lot allocation $(P \geq 0.9415)$. This pairwise homogeneity is particularly important in the virtual/paired-release design where the downstream pair is used to estimate the extra-reach mortality needed to adjust the survival estimate from the virtual forebay release.

Tests of homogeneous reach survivals across tag lots by release locations were performed (Table A.5). These tests looked for any tag-lot effects not accounted for by the tag-lot-specific tag-life corrections. Of the 56 tests of homogeneous reach survivals across tag lots, 11 were significant at $P \leq 0.10$ (i.e., 19\%). However, there was no particular pattern to the lot-specific reach survivals. Tag lot 1 had the lowest survival in 3 of the 11 significant tests; lot 2 had the lower survival in 3 tests, and lots $3-5$ had the lowest survival in 5 tests.

In the 54 tests of homogeneous cumulative survival, 9 were significant at $P \leq 0.10$ (i.e., $16.7 \%$ ). However, the tests of cumulative survival are not independent within an analysis of a release group. For example, 7 of the 9 significant results all occurred within the $R_{1}$ release of steelhead. Also in that case, tag lot 1 had the lowest survivals in 2 of the 7 instances, while tag lot 2 had the lowest survival in 5 instances.

We conclude that tag lots corrected for tag life have no significant effect on observed smolt survivals. Therefore, fish tagged from all tag lots should be used in the analyses. 
Table A.4. Numbers of tags used per tag lot at each release location for (a) yearling Chinook salmon and (b) steelhead smolts in the 2011 JSATS survival study. Chi-square tests of homogeneity performed for the overall table and pairwise comparisons of the below-dam release pairs.

a. Yearling Chinook salmon

\begin{tabular}{|c|c|c|c|c|}
\hline \multirow{2}{*}{ Release location } & \multicolumn{3}{|c|}{ Tag lot } & \multirow{2}{*}{ P-value } \\
\cline { 2 - 4 } & 1 & 2 & $3,4,5$ & \\
\hline R1-CR390 & 706 & 501 & 1303 & \\
\hline R2-CR346 & 226 & 302 & 665 & \multirow{2}{*}{0.9801} \\
\hline R3-CR325 & 150 & 200 & 449 & \\
\hline R4-CR307 & 150 & 149 & 500 & \multirow{2}{*}{0.9805} \\
\hline R5-CR275 & 150 & 146 & 503 & \\
\hline R6-CR233 & 100 & 150 & 548 & \multirow{2}{*}{0.9323} \\
\hline R7-CR161 & 96 & 146 & 552 & \\
\hline Chi-square =211.77 & DF $=12$ & & $<0.0001$ \\
\hline
\end{tabular}

b. Steelhead

\begin{tabular}{|c|r|c|c|c|}
\hline \multirow{2}{*}{ Release location } & \multicolumn{3}{|c|}{ Tag lot } & \multirow{2}{*}{} \\
\cline { 2 - 4 } & 1 & 2 & $3,4,5$ & -value \\
\hline R1-CR390 & 698 & 498 & 1391 & \\
\hline R2-CR346 & 228 & 302 & 666 & \multirow{2}{*}{0.9415} \\
\hline R3-CR325 & 150 & 197 & 450 & \\
\hline R4-CR307 & 150 & 150 & 500 & \multirow{2}{*}{1.0000} \\
\hline R5-CR275 & 150 & 150 & 500 & \\
\hline R6-CR233 & 99 & 146 & 547 & \multirow{2}{*}{0.9681} \\
\hline R7-CR161 & 100 & 150 & 544 & \\
\hline Chi-square $=178.67$ & DF $=12$ & & $<0.0001$ \\
\hline
\end{tabular}


Table A.5. Estimates of reach survival and cumulative survival for (a) yearling Chinook salmon and (b) steelhead smolts, along with $P$-values associated with the $F$-tests of homogeneous survival across tag lots.

a. Yearling Chinook salmon smolts

1) Release 1-Reach survival

\begin{tabular}{|c|c|c|c|c|c|c|c|c|c|c|c|c|c|c|}
\hline & \multicolumn{2}{|c|}{ Release to CR349 } & \multicolumn{2}{|c|}{ CR349 to CR325 } & \multicolumn{2}{|c|}{ CR325 to CR309 } & \multicolumn{2}{|c|}{ CR309 to CR275 } & \multicolumn{2}{|c|}{ CR275 to CR234 } & \multicolumn{2}{|c|}{ CR234 to CR161 } & \multicolumn{2}{|c|}{ CR161 to CR113 } \\
\hline & $\hat{S}$ & $\widehat{\mathrm{SE}}$ & $\hat{S}$ & $\widehat{\mathrm{SE}}$ & $\hat{S}$ & $\widehat{\mathrm{SE}}$ & $\hat{S}$ & $\widehat{\mathrm{SE}}$ & $\hat{S}$ & $\widehat{\mathrm{SE}}$ & $\hat{S}$ & $\widehat{\mathrm{SE}}$ & $\hat{S}$ & $\widehat{\mathrm{SE}}$ \\
\hline Lot 1 & 0.9802 & 0.0052 & 0.9578 & 0.0077 & 0.9924 & 0.0034 & 0.9664 & 0.0071 & 0.9937 & 0.0032 & 0.9587 & 0.0081 & 1.0025 & 0.0041 \\
\hline Lot 2 & 0.9801 & 0.0063 & 0.9528 & 0.0096 & 0.9914 & 0.0043 & 0.9501 & 0.0101 & 0.9954 & 0.0032 & 0.9570 & 0.0107 & 0.9839 & 0.0124 \\
\hline Lot $3,4,5$ & 0.9762 & 0.0042 & 0.9672 & 0.0050 & 0.9922 & 0.0027 & 0.9665 & 0.0053 & 0.9951 & 0.0022 & 0.9719 & 0.0095 & 0.9512 & 0.0226 \\
\hline$P$-value & \multicolumn{2}{|c|}{0.8312} & \multicolumn{2}{|c|}{0.4029} & \multicolumn{2}{|c|}{0.9774} & \multicolumn{2}{|c|}{0.2268} & \multicolumn{2}{|c|}{0.9067} & \multicolumn{2}{|c|}{0.4775} & \multicolumn{2}{|c|}{0.0520} \\
\hline
\end{tabular}

2) Release 1 - Cumulative survival

\begin{tabular}{|c|c|c|c|c|c|c|c|c|c|c|c|c|c|c|}
\hline & \multicolumn{2}{|c|}{ Release to CR349 } & \multicolumn{2}{|c|}{ Release to CR325 } & \multicolumn{2}{|c|}{ Release to CR309 } & \multicolumn{2}{|c|}{ Release to CR275 } & \multicolumn{2}{|c|}{ Release to CR234 } & \multicolumn{2}{|c|}{ Release to CR161 } & \multicolumn{2}{|c|}{ Release to CR113 } \\
\hline & $\hat{\hat{S}}$ & $\widehat{\mathrm{SE}}$ & $\overline{\hat{S}}$ & $\widehat{\mathrm{SE}}$ & $\hat{\hat{S}}$ & $\widehat{\mathrm{SE}}$ & $\hat{\hat{S}}$ & $\widehat{\mathrm{SE}}$ & $\hat{S}$ & $\widehat{\mathrm{SE}}$ & $\hat{\hat{S}}$ & $\widehat{\mathrm{SE}}$ & $\hat{\hat{S}}$ & $\widehat{\mathrm{SE}}$ \\
\hline Lot 1 & 0.9802 & 0.0052 & 0.9389 & 0.0090 & 0.9317 & 0.0095 & 0.9004 & 0.0113 & 0.8947 & 0.0116 & 0.8577 & 0.0133 & 0.8598 & 0.0138 \\
\hline Lot 2 & 0.9801 & 0.0063 & 0.9338 & 0.0111 & 0.9258 & 0.0117 & 0.8796 & 0.0146 & 0.8756 & 0.0148 & 0.8380 & 0.0170 & 0.8245 & 0.0191 \\
\hline Lot $3,4,5$ & 0.9762 & 0.0042 & 0.9442 & 0.0064 & 0.9368 & 0.0068 & 0.9054 & 0.0081 & 0.9009 & 0.0083 & 0.8756 & 0.0117 & 0.8329 & 0.0205 \\
\hline$P$-value & \multicolumn{2}{|c|}{$\frac{1}{0.8312}$} & \multicolumn{2}{|c|}{0.7192} & \multicolumn{2}{|c|}{0.7177} & \multicolumn{2}{|c|}{0.2511} & \multicolumn{2}{|c|}{0.2898} & \multicolumn{2}{|c|}{0.1713} & \multicolumn{2}{|c|}{0.3508} \\
\hline
\end{tabular}

3) Release 2-Reach survival

\begin{tabular}{|c|c|c|c|c|c|c|c|c|c|c|c|c|}
\hline & \multicolumn{2}{|c|}{ CR349 to CR325 } & \multicolumn{2}{|c|}{ CR325 to CR309 } & \multicolumn{2}{|c|}{ CR309 to CR275 } & \multicolumn{2}{|c|}{ CR275 to CR234 } & \multicolumn{2}{|c|}{ CR234 to CR161 } & \multicolumn{2}{|c|}{ CR161 to CR113 } \\
\hline & $\hat{S}$ & $\widehat{\mathrm{SE}}$ & $\overline{\hat{S}}$ & $\widehat{\mathrm{SE}}$ & $\hat{\hat{S}}$ & $\widehat{\mathrm{SE}}$ & $\hat{S}$ & $\widehat{\mathrm{SE}}$ & $\hat{\hat{S}}$ & $\widehat{\mathrm{SE}}$ & $\hat{\hat{S}}$ & $\widehat{\mathrm{SE}}$ \\
\hline Lot 1 & 0.9912 & 0.0062 & 0.9869 & 0.0077 & 0.9409 & 0.0159 & 0.9952 & 0.0048 & 0.9662 & 0.0127 & 0.9762 & 0.0127 \\
\hline Lot 2 & 0.9868 & 0.0066 & 0.9799 & 0.0081 & 0.9623 & 0.0111 & 0.9893 & 0.0061 & 0.9498 & 0.0132 & 1.0133 & 0.0066 \\
\hline Lot $3,4,5$ & 0.9913 & 0.0037 & 0.9939 & 0.0032 & 0.9531 & 0.0084 & 0.9961 & 0.0027 & 0.9688 & 0.0139 & 0.9316 & 0.0296 \\
\hline$P$-value & \multicolumn{2}{|c|}{0.8128} & \multicolumn{2}{|c|}{0.3376} & \multicolumn{2}{|c|}{0.4611} & \multicolumn{2}{|c|}{0.5483} & \multicolumn{2}{|c|}{0.5465} & \multicolumn{2}{|c|}{0.0096} \\
\hline
\end{tabular}


Table A.5. (contd)

4) Release 2-Cumulative survival

\begin{tabular}{|c|c|c|c|c|c|c|c|c|c|c|c|c|}
\hline & \multicolumn{2}{|c|}{ Release to CR325 } & \multicolumn{2}{|c|}{ Release to CR309 } & \multicolumn{2}{|c|}{ Release to CR275 } & \multicolumn{2}{|c|}{ Release to CR234 } & \multicolumn{2}{|c|}{ Release to CR161 } & \multicolumn{2}{|c|}{ Release to CR113 } \\
\hline & $\hat{S}$ & $\widehat{\mathrm{SE}}$ & $\hat{S}$ & $\widehat{\mathrm{SE}}$ & $\hat{S}$ & $\widehat{\mathrm{SE}}$ & $\hat{S}$ & $\widehat{\mathrm{SE}}$ & $\hat{S}$ & $\widehat{\mathrm{SE}}$ & $\hat{S}$ & $\widehat{\mathrm{SE}}$ \\
\hline Lot 1 & 0.9912 & 0.0062 & 0.9782 & 0.0098 & 0.9204 & 0.0180 & 0.9159 & 0.0185 & 0.8849 & 0.0213 & 0.8639 & 0.0236 \\
\hline Lot 2 & 0.9868 & 0.0066 & 0.9669 & 0.0103 & 0.9305 & 0.0146 & 0.9205 & 0.0156 & 0.8743 & 0.0191 & 0.8860 & 0.0201 \\
\hline Lot $3,4,5$ & 0.9913 & 0.0037 & 0.9852 & 0.0047 & 0.9390 & 0.0093 & 0.9353 & 0.0095 & 0.9061 & 0.0159 & 0.8441 & 0.0269 \\
\hline$P$-value & \multicolumn{2}{|c|}{0.8128} & \multicolumn{2}{|c|}{0.3195} & \multicolumn{2}{|c|}{0.6600} & \multicolumn{2}{|c|}{0.6329} & \multicolumn{2}{|c|}{0.4803} & \multicolumn{2}{|c|}{0.4571} \\
\hline
\end{tabular}

5) Release 3-Reach survival

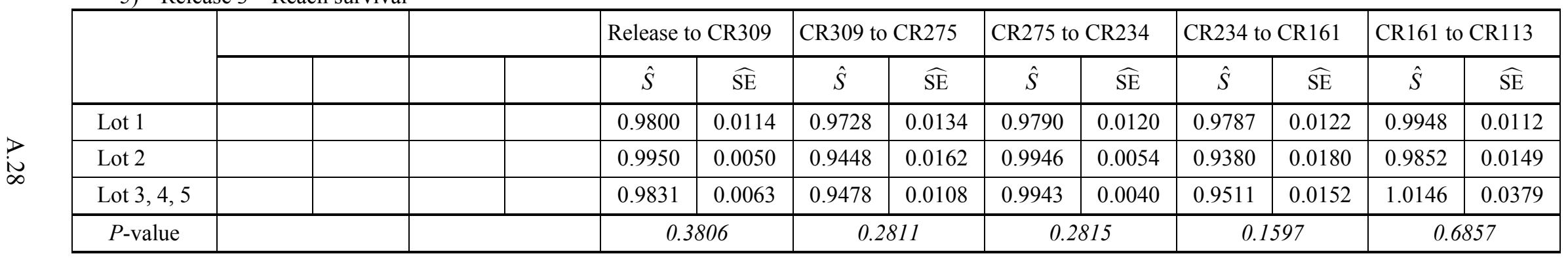

6) Release 3 -Cumulative survival

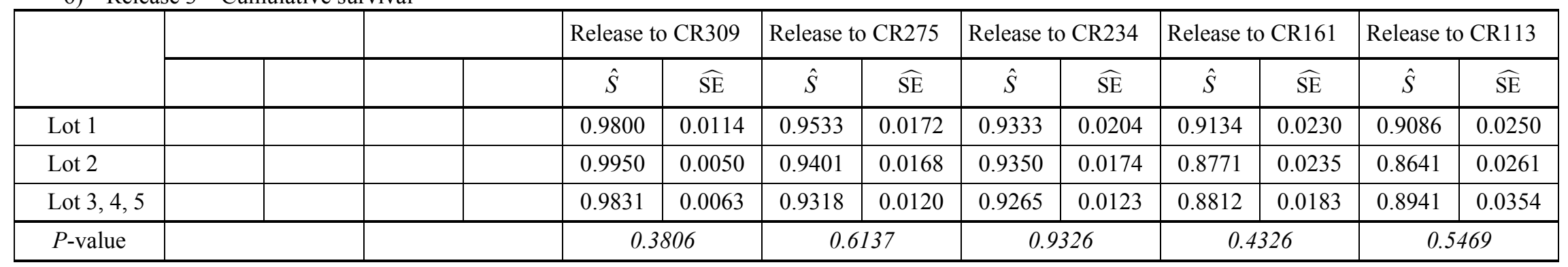


Table A.5. (contd)

7) Release 4 - Reach survival

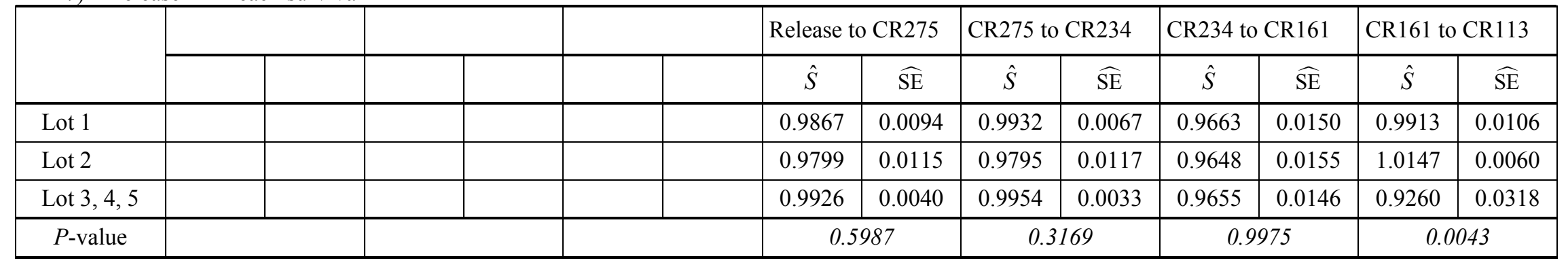

8) Release 4-Cumulative survival

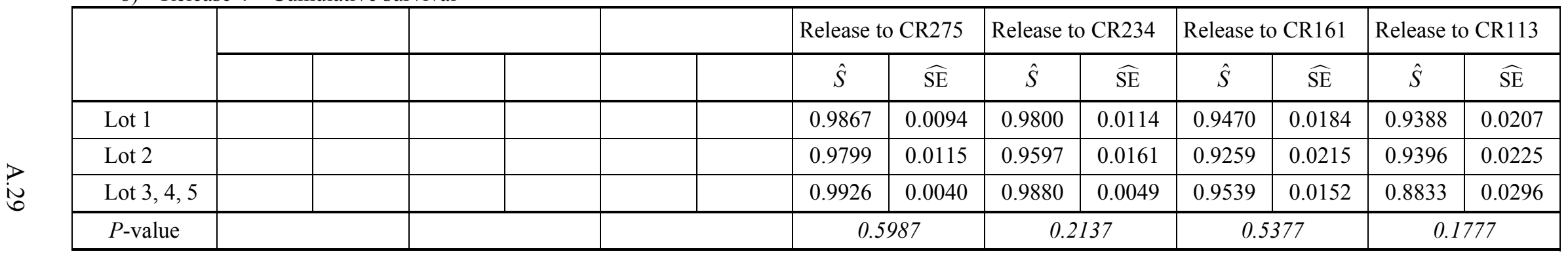

9) Release 5-Reach survival

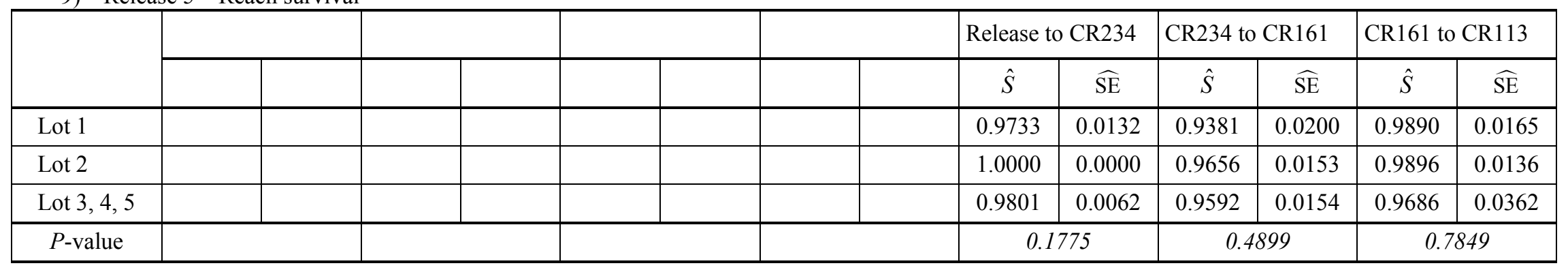


Table A.5. (contd)

10) Release 5-Cumulative survival

\begin{tabular}{|c|c|c|c|c|c|c|c|}
\hline \multicolumn{2}{|c|}{} & \multicolumn{3}{|c|}{ Release to CR234 } & Release to CR161 & \multicolumn{2}{l|}{ Release to CR113 } \\
\hline & & $\hat{S}$ & $\widehat{\mathrm{SE}}$ & $\hat{S}$ & $\widehat{\mathrm{SE}}$ & $\hat{S}$ & $\widehat{\mathrm{SE}}$ \\
\hline & & 0.9733 & 0.0132 & 0.9131 & 0.0231 & 0.9031 & 0.0273 \\
\hline & 1.0000 & 0.0000 & 0.9656 & 0.0153 & 0.9556 & 0.0199 \\
\hline & 0.9801 & 0.0062 & 0.9401 & 0.0162 & 0.9106 & 0.0335 \\
\hline & & \multicolumn{2}{|c|}{0.1775} & \multicolumn{2}{|c|}{0.1338} & \multicolumn{3}{c|}{0.3440} \\
\hline
\end{tabular}

11) Release 6 - Reach survival

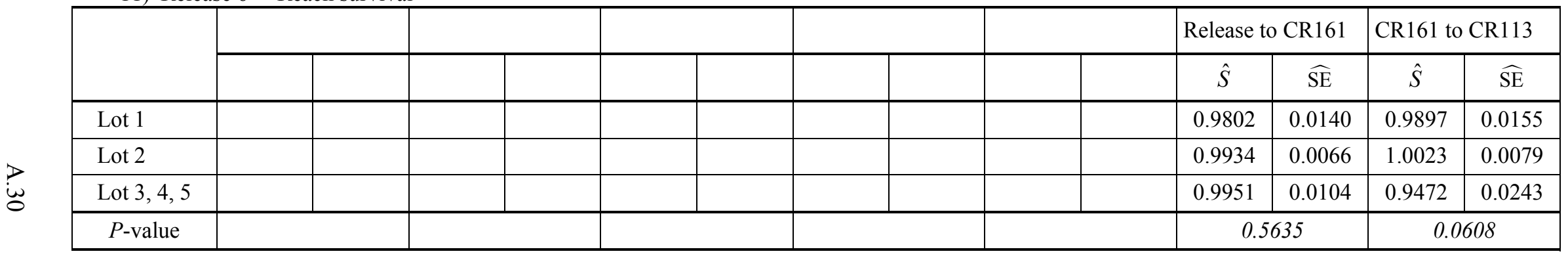

12) Release 6 -Cumulative survival

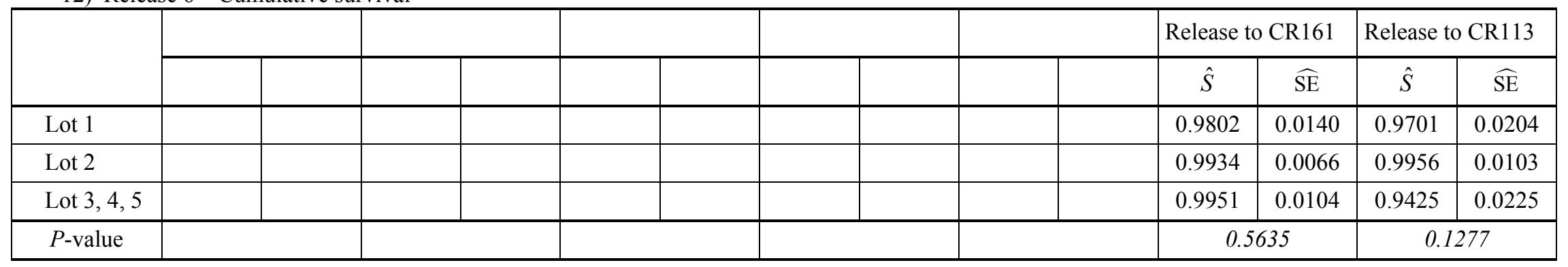


Table A.5. (contd)

13) Release 7 - Reach survival

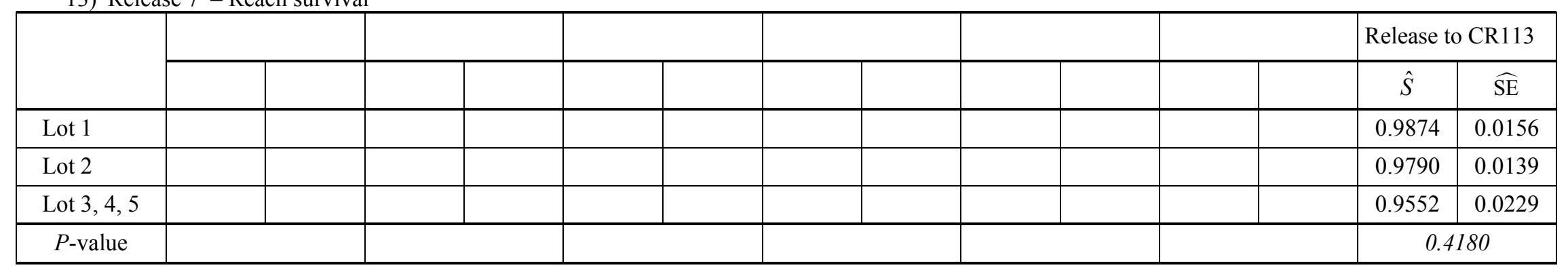


Table A.5. (contd)

b. Steelhead smolts

14) Release 1 - Reach survival

\begin{tabular}{|c|c|c|c|c|c|c|c|c|c|c|c|c|c|c|}
\hline & \multicolumn{2}{|c|}{ Release to CR349 } & \multicolumn{2}{|c|}{ CR349 to CR325 } & \multicolumn{2}{|c|}{ CR325 to CR309 } & \multicolumn{2}{|c|}{ CR309 to CR275 } & \multicolumn{2}{|c|}{ CR275 to CR234 } & \multicolumn{2}{|c|}{ CR234 to CR161 } & \multicolumn{2}{|c|}{ CR161 to CR113 } \\
\hline & $\hat{\hat{S}}$ & $\widehat{\mathrm{SE}}$ & $\hat{\hat{S}}$ & $\widehat{\mathrm{SE}}$ & $\overline{\hat{S}}$ & $\widehat{\widehat{S E}}$ & $\overline{\hat{S}}$ & $\widehat{\mathrm{SE}}$ & $\overline{\hat{S}}$ & $\widehat{\mathrm{SE}}$ & $\overline{\hat{S}}$ & $\widehat{\mathrm{SE}}$ & $\overline{\hat{S}}$ & $\widehat{\mathrm{SE}}$ \\
\hline Lot 1 & 0.9571 & 0.0077 & 0.9623 & 0.0074 & 0.9907 & 0.0038 & 0.9637 & 0.0074 & 0.9771 & 0.0061 & 0.9691 & 0.0072 & 1.0002 & 0.0083 \\
\hline Lot 2 & 0.9318 & 0.0113 & 0.9761 & 0.0071 & 0.9957 & 0.0031 & 0.9756 & 0.0073 & 0.9725 & 0.0078 & 0.9427 & 0.0117 & 0.9965 & 0.0137 \\
\hline Lot $3,4,5$ & 0.9705 & 0.0045 & 0.9809 & 0.0038 & 0.9932 & 0.0023 & 0.9858 & 0.0036 & 0.9902 & 0.0031 & 0.9492 & 0.0083 & 0.9969 & 0.0258 \\
\hline$P$-value & \multicolumn{2}{|c|}{0.0037} & \multicolumn{2}{|c|}{0.0960} & \multicolumn{2}{|c|}{0.5329} & \multicolumn{2}{|c|}{0.0489} & \multicolumn{2}{|c|}{0.0945} & \multicolumn{2}{|c|}{0.1095} & \multicolumn{2}{|c|}{0.9867} \\
\hline
\end{tabular}

15) Release 1 - Cumulative survival

\begin{tabular}{|c|c|c|c|c|c|c|c|c|c|c|c|c|c|c|}
\hline & \multicolumn{2}{|c|}{ Release to CR349 } & \multicolumn{2}{|c|}{ Release to CR325 } & \multicolumn{2}{|c|}{ Release to CR309 } & \multicolumn{2}{|c|}{ Release to CR275 } & \multicolumn{2}{|c|}{ Release to CR234 } & \multicolumn{2}{|c|}{ Release to CR161 } & \multicolumn{2}{|c|}{ Release to CR113 } \\
\hline & $\hat{S}$ & $\widehat{\mathrm{SE}}$ & $\hat{\hat{S}}$ & $\widehat{\mathrm{SE}}$ & $\hat{\hat{S}}$ & $\widehat{\mathrm{SE}}$ & $\hat{S}$ & $\widehat{\mathrm{SE}}$ & $\hat{\hat{S}}$ & $\widehat{\mathrm{SE}}$ & $\hat{S}$ & $\widehat{\mathrm{SE}}$ & $\hat{S}$ & $\widehat{\mathrm{SE}}$ \\
\hline Lot 1 & 0.9571 & 0.0077 & 0.9211 & 0.0102 & 0.9125 & 0.0107 & 0.8793 & 0.0123 & 0.8592 & 0.0132 & 0.8326 & 0.0142 & 0.8328 & 0.0158 \\
\hline Lot 2 & 0.9318 & 0.0113 & 0.9096 & 0.0129 & 0.9057 & 0.0131 & 0.8835 & 0.0144 & 0.8593 & 0.0156 & 0.8101 & 0.0178 & 0.8072 & 0.0207 \\
\hline Lot $3,4,5$ & 0.9705 & 0.0045 & 0.9520 & 0.0057 & 0.9455 & 0.0061 & 0.9321 & 0.0069 & 0.9229 & 0.0072 & 0.8760 & 0.0102 & 0.8734 & 0.0237 \\
\hline$P$-value & \multicolumn{2}{|c|}{0.0037} & \multicolumn{2}{|c|}{0.0085} & \multicolumn{2}{|c|}{0.0150} & \multicolumn{2}{|c|}{0.0017} & \multicolumn{2}{|c|}{0.0002} & \multicolumn{2}{|c|}{0.0045} & \multicolumn{2}{|c|}{0.0674} \\
\hline
\end{tabular}

16) Release 2 - Reach survival

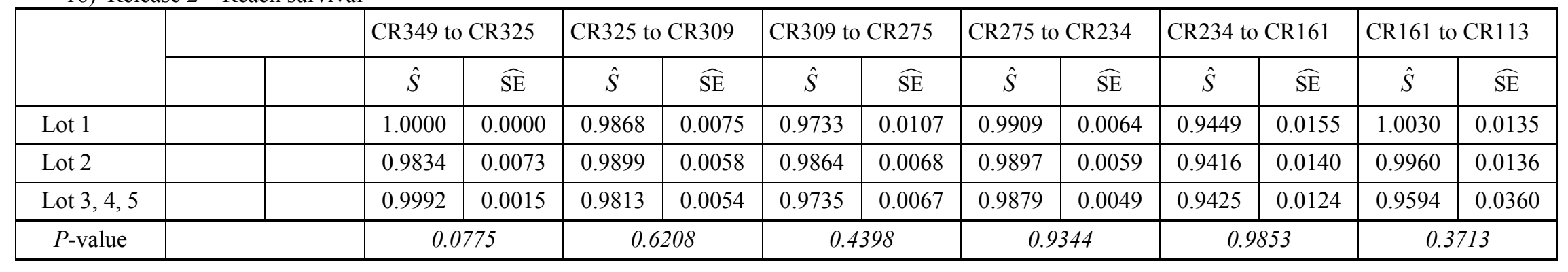


Table A.5. (contd)

17) Release 2 - Cumulative survival

\begin{tabular}{|c|c|c|c|c|c|c|c|c|c|c|c|c|}
\hline & \multicolumn{2}{|c|}{ Release to CR325 } & \multicolumn{2}{|c|}{ Release to CR309 } & \multicolumn{2}{|c|}{ Release to CR275 } & \multicolumn{2}{|c|}{ Release to CR234 } & \multicolumn{2}{|c|}{ Release to CR161 } & \multicolumn{2}{|c|}{ Release to CR113 } \\
\hline & $\hat{S}$ & $\widehat{\mathrm{SE}}$ & $\hat{S}$ & $\widehat{\mathrm{SE}}$ & $\hat{S}$ & $\widehat{\mathrm{SE}}$ & $\hat{S}$ & $\widehat{\mathrm{SE}}$ & $\hat{S}$ & $\widehat{\mathrm{SE}}$ & $\hat{S}$ & $\widehat{\mathrm{SE}}$ \\
\hline Lot 1 & 1.0000 & 0.0000 & 0.9868 & 0.0075 & 0.9605 & 0.0129 & 0.9518 & 0.0142 & 0.8993 & 0.0200 & 0.9021 & 0.0234 \\
\hline Lot 2 & 0.9834 & 0.0073 & 0.9735 & 0.0092 & 0.9603 & 0.0112 & 0.9503 & 0.0125 & 0.8949 & 0.0177 & 0.8913 & 0.0213 \\
\hline Lot $3,4,5$ & 0.9992 & 0.0015 & 0.9805 & 0.0054 & 0.9545 & 0.0084 & 0.9429 & 0.0090 & 0.8887 & 0.0145 & 0.8526 & 0.0332 \\
\hline$P$-value & \multicolumn{2}{|c|}{0.0775} & \multicolumn{2}{|c|}{0.4602} & \multicolumn{2}{|c|}{0.9084} & \multicolumn{2}{|c|}{0.8561} & \multicolumn{2}{|c|}{0.9118} & \multicolumn{2}{|c|}{0.3803} \\
\hline
\end{tabular}

18) Release 3 - Reach survival

\begin{tabular}{|c|c|c|c|c|c|c|c|c|c|c|}
\hline & \multicolumn{2}{|c|}{ Release to CR309 } & \multicolumn{2}{|c|}{ CR309 to CR275 } & \multicolumn{2}{|c|}{ CR275 to CR234 } & \multicolumn{2}{|c|}{ CR234 to CR161 } & \multicolumn{2}{|c|}{ CR161 to CR113 } \\
\hline & $\hat{S}$ & $\widehat{\mathrm{SE}}$ & $\hat{S}$ & $\widehat{\mathrm{SE}}$ & $\hat{S}$ & $\widehat{\mathrm{SE}}$ & $\hat{S}$ & $\widehat{\mathrm{SE}}$ & $\hat{S}$ & $\widehat{\mathrm{SE}}$ \\
\hline Lot 1 & 0.9933 & 0.0066 & 0.9866 & 0.0094 & 0.9796 & 0.0117 & 0.9376 & 0.0202 & 1.0246 & 0.0164 \\
\hline Lot 2 & 0.9898 & 0.0071 & 0.9282 & 0.0185 & 0.9669 & 0.0133 & 0.9675 & 0.0138 & 0.9913 & 0.0193 \\
\hline Lot $3,4,5$ & 0.9912 & 0.0044 & 0.9737 & 0.0081 & 0.9878 & 0.0061 & 0.9577 & 0.0144 & 1.0688 & 0.0563 \\
\hline$P$-value & \multicolumn{2}{|c|}{0.9221} & \multicolumn{2}{|c|}{0.0034} & \multicolumn{2}{|c|}{0.3863} & \multicolumn{2}{|c|}{0.4209} & \multicolumn{2}{|c|}{0.3039} \\
\hline
\end{tabular}

19) Release 3 -Cumulative survival

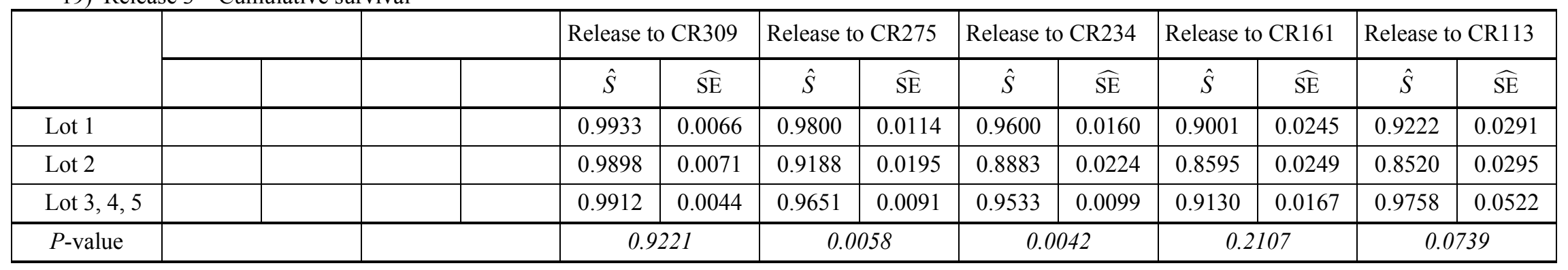


Table A.5. (contd)

20) Release 4 - Reach survival

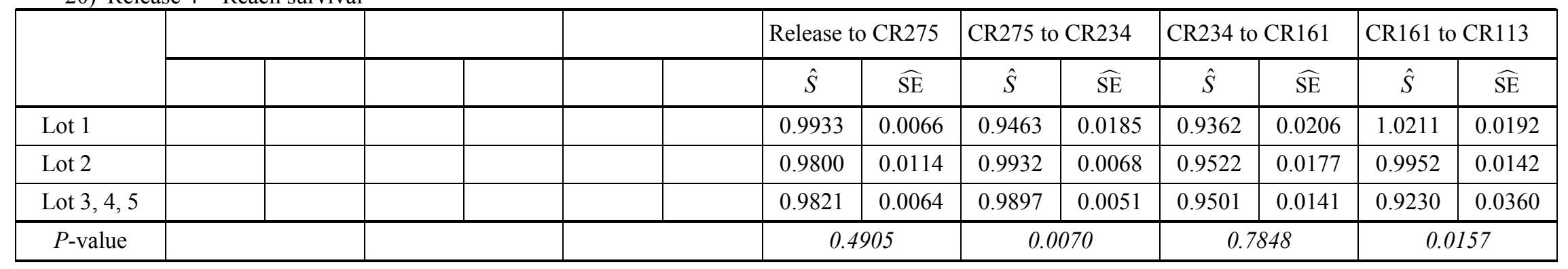

21) Release 4 - Cumulative survival

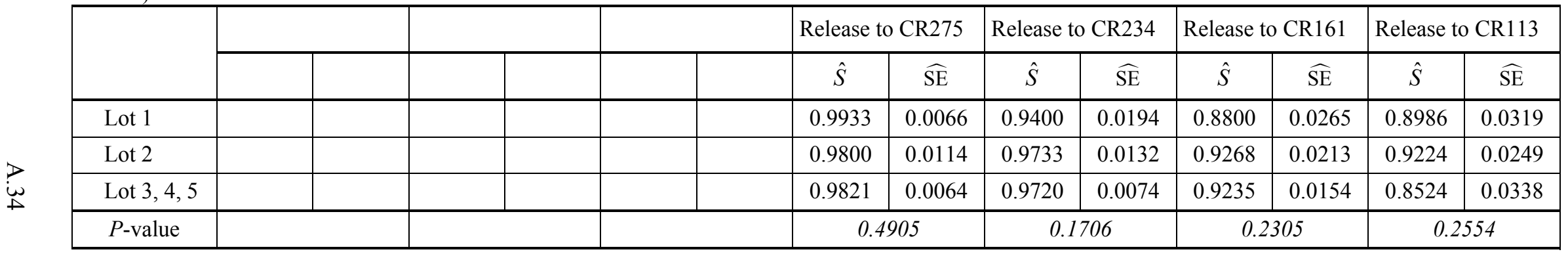

22) Release 5 - Reach survival

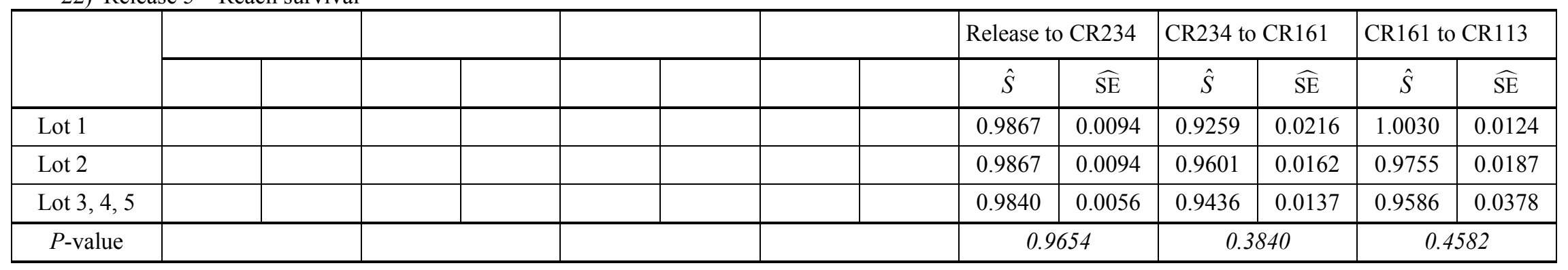


Table A.5. (contd)

23) Release 5-Cumulative survival

\begin{tabular}{|c|c|c|c|c|c|c|c|}
\hline \multicolumn{2}{|c|}{} & \multicolumn{3}{|c|}{ Release to CR234 } & Release to CR161 & Release to CR113 \\
\hline & & $\hat{S}$ & $\widehat{\mathrm{SE}}$ & $\hat{S}$ & $\widehat{\mathrm{SE}}$ & $\hat{S}$ & $\widehat{\mathrm{SE}}$ \\
\hline & & 0.9867 & 0.0094 & 0.9135 & 0.0230 & 0.9163 & 0.0256 \\
\hline & 0.9867 & 0.0094 & 0.9473 & 0.0184 & 0.9241 & 0.0250 \\
\hline & 0.9840 & 0.0056 & 0.9285 & 0.0145 & 0.8901 & 0.0358 \\
\hline & \multicolumn{6}{|c|}{0.9654} & \multicolumn{2}{|c|}{0.4494} & \multicolumn{6}{c|}{0.6900} \\
\hline
\end{tabular}

24) Release 6 - Reach survival

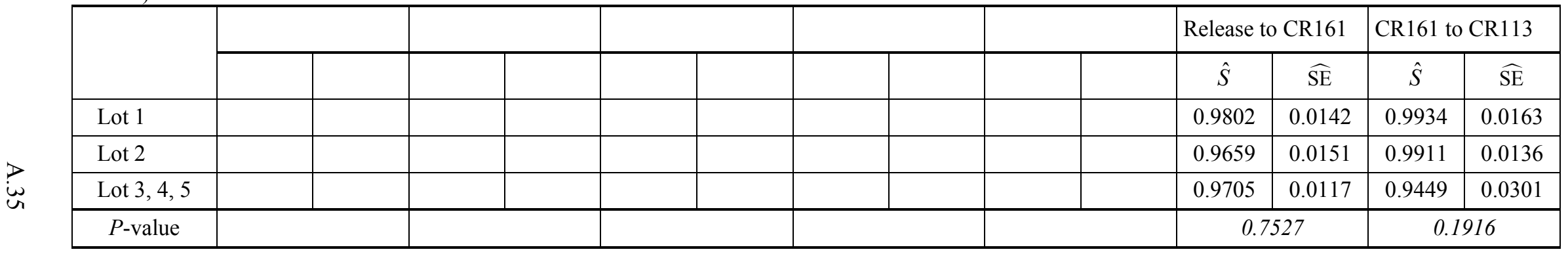

25) Release 6-Cumulative survival

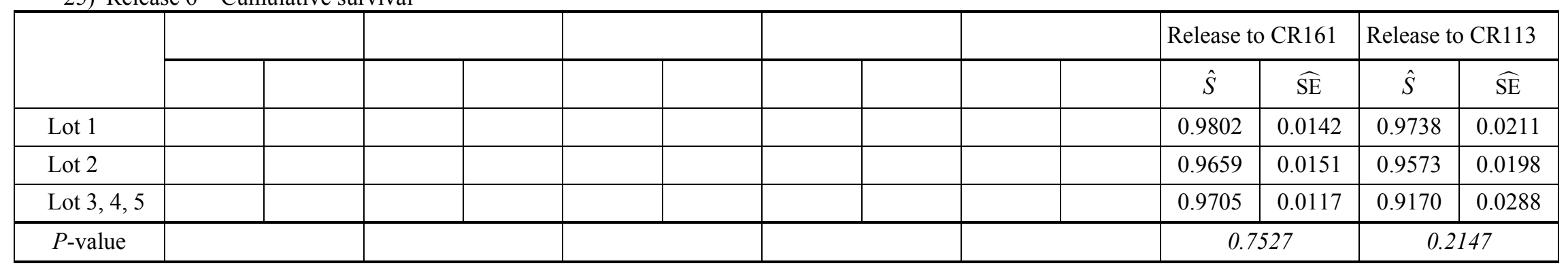


Table A.5. (contd)

26) Release 7 - Reach survival

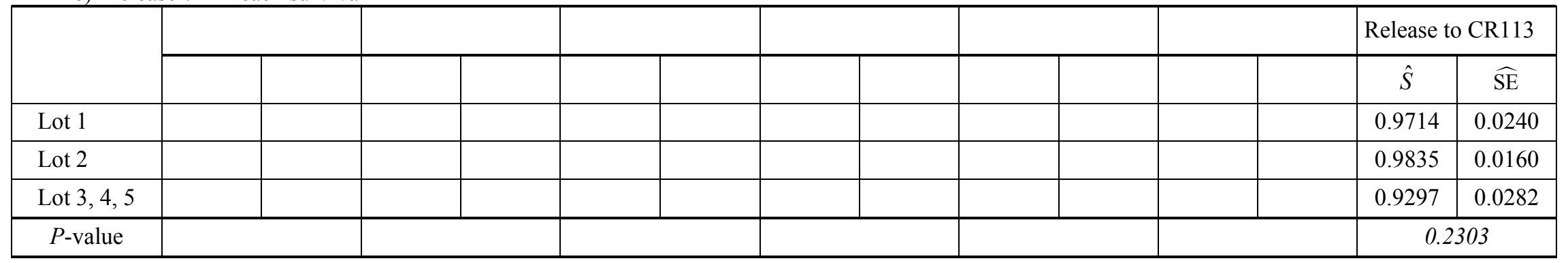




\section{A.3 Examination of Delayed Handling Effects}

The purpose of these tests was to assess whether downstream reach survivals were affected by how far upstream smolts were released. The results of these tests were used to determine which release groups were included in the constructs of a downstream virtual-release group. Data were pooled across taggers and tag lots in performing these analyses because previous tests of tag-lot and tagger effects were nonsignificant.

One of the 10 reach comparisons was significant at $\alpha=0.10$. In those 10 cases, the survival estimates typically differed by less than 0.01 , and reach survival for the uppermost release group was often higher than that of the downriver release groups (Table A.6). Comparison of cumulative survivals in reaches common to multiple release groups found 4 of 30 (i.e., $13.3 \%$ ) tests to be significant at $\square=0.10$ (Table A.7). In all cases, the upper release group $\left(R_{1}\right)$ had higher survival than a group released further downriver. These observations are not consistent with evidence of time-dependent tag effects.

Therefore, no evidence was found that a delayed handling/tag effect may affect the survival studies. For this reason, all available upriver releases were used in the construction of virtual-release groups at the face of John Day, The Dalles, and Bonneville dams. 
Table A.6. Comparison of reach survivals between tag releases from different upstream locations for (a) yearling Chinook salmon and (b) steelhead during the 2011 JSATS survival study. Shaded reach survivals were not included in the $F$-tests of homogeneous survival because they represent new releases. Newly released fish and previously released fish were not compared within a reach.

a. Yearling Chinook salmon

\begin{tabular}{|c|c|c|c|c|c|c|c|c|c|c|c|c|c|c|c|}
\hline \multirow[b]{2}{*}{ Reach } & \multicolumn{2}{|c|}{ CR390 } & \multicolumn{2}{|c|}{ CR346 } & \multicolumn{2}{|c|}{ CR325 } & \multicolumn{2}{|c|}{ CR307 } & \multicolumn{2}{|c|}{ CR275 } & \multicolumn{2}{|c|}{ CR233 } & \multicolumn{2}{|c|}{ CR161 } & \multirow[b]{2}{*}{$P(F$-test } \\
\hline & $\hat{S}$ & $\widehat{\mathrm{SE}}$ & $\hat{S}$ & $\widehat{\mathrm{SE}}$ & $\hat{S}$ & $\widehat{\mathrm{SE}}$ & $\hat{S}$ & $\widehat{\mathrm{SE}}$ & $\hat{S}$ & $\widehat{\mathrm{SE}}$ & $\hat{S}$ & $\widehat{\mathrm{SE}}$ & $\hat{S}$ & $\widehat{\mathrm{SE}}$ & \\
\hline Release to CR349 & 0.9810 & 0.0029 & & & & & & & & & & & & & \\
\hline CR349 to CR325 & 0.9620 & 0.0039 & 0.9923 & 0.0029 & & & & & & & & & & & \\
\hline CR325 to CR309 & 0.9924 & 0.0019 & 0.9892 & 0.0031 & 0.9874 & 0.0043 & & & & & & & & & 0.3788 \\
\hline CR309 to CR275 & 0.9636 & 0.0039 & 0.9538 & 0.0062 & 0.9525 & 0.0077 & 0.9915 & 0.0038 & & & & & & & 0.3760 \\
\hline CR275 to CR234 & 0.9954 & 0.0016 & 0.9947 & 0.0024 & 0.9919 & 0.0036 & 0.9924 & 0.0034 & 0.9851 & 0.0047 & & & & & 0.7845 \\
\hline CR234 to CR161 & 0.9551 & 0.0054 & 0.9518 & 0.0080 & 0.9464 & 0.0095 & 0.9541 & 0.0092 & 0.9451 & 0.0099 & 0.9863 & 0.0067 & & & 0.8916 \\
\hline CR161 to CR113 & 0.9577 & 0.0094 & 0.9515 & 0.0133 & 0.9799 & 0.0155 & 0.9467 & 0.0161 & 0.9571 & 0.0176 & 0.9586 & 0.0144 & 0.9479 & 0.0141 & 0.6943 \\
\hline \multicolumn{16}{|l|}{ b. Steelhead } \\
\hline & \multicolumn{2}{|c|}{ CR390 } & \multicolumn{2}{|c|}{ CR346 } & \multicolumn{2}{|c|}{ CR325 } & \multicolumn{2}{|c|}{ CR307 } & \multicolumn{2}{|c|}{ CR275 } & \multicolumn{2}{|c|}{ CR233 } & \multicolumn{2}{|c|}{ CR161 } & \\
\hline Reach & $\hat{S}$ & $\widehat{\mathrm{SE}}$ & $\hat{S}$ & $\widehat{\mathrm{SE}}$ & $\hat{S}$ & $\widehat{\mathrm{SE}}$ & $\hat{S}$ & $\widehat{\mathrm{SE}}$ & $\hat{S}$ & $\widehat{\mathrm{SE}}$ & $\hat{S}$ & $\widehat{\mathrm{SE}}$ & $\hat{S}$ & $\widehat{\mathrm{SE}}$ & $P(F$-test $)$ \\
\hline Release to CR349 & 0.9623 & 0.0039 & & & & & & & & & & & & & \\
\hline CR349 to CR325 & 0.9757 & 0.0032 & 0.9975 & 0.0020 & & & & & & & & & & & \\
\hline CR325 to CR309 & 0.9932 & 0.0017 & 0.9847 & 0.0036 & 0.9932 & 0.0033 & & & & & & & & & 0.0328 \\
\hline CR309 to CR275 & 0.9795 & 0.0031 & 0.9769 & 0.0046 & 0.9663 & 0.0068 & 0.9867 & 0.0047 & & & & & & & 0.1489 \\
\hline CR275 to CR234 & 0.9831 & 0.0029 & 0.9895 & 0.0033 & 0.9807 & 0.0054 & 0.9816 & 0.0052 & 0.9874 & 0.0043 & & & & & 0.4732 \\
\hline CR234 to CR161 & 0.9480 & 0.0052 & 0.9367 & 0.0080 & 0.9495 & 0.0092 & 0.9401 & 0.0097 & 0.9379 & 0.0096 & 0.9659 & 0.0082 & & & 0.7484 \\
\hline CR161 to CR113 & 0.9691 & 0.0107 & 0.9528 & 0.0151 & 0.9938 & 0.0208 & 0.9451 & 0.0189 & 0.9445 & 0.0178 & 0.9501 & 0.0175 & 0.9258 & 0.0167 & 0.2810 \\
\hline
\end{tabular}


Table A.7. Comparison of cumulative survivals between different upstream tag-release locations for (a) yearling Chinook salmon and (b) steelhead during the 2011 JSATS survival study. $P$-values associated with $F$-tests of homogeneous survival.

a. Yearling Chinook salmon

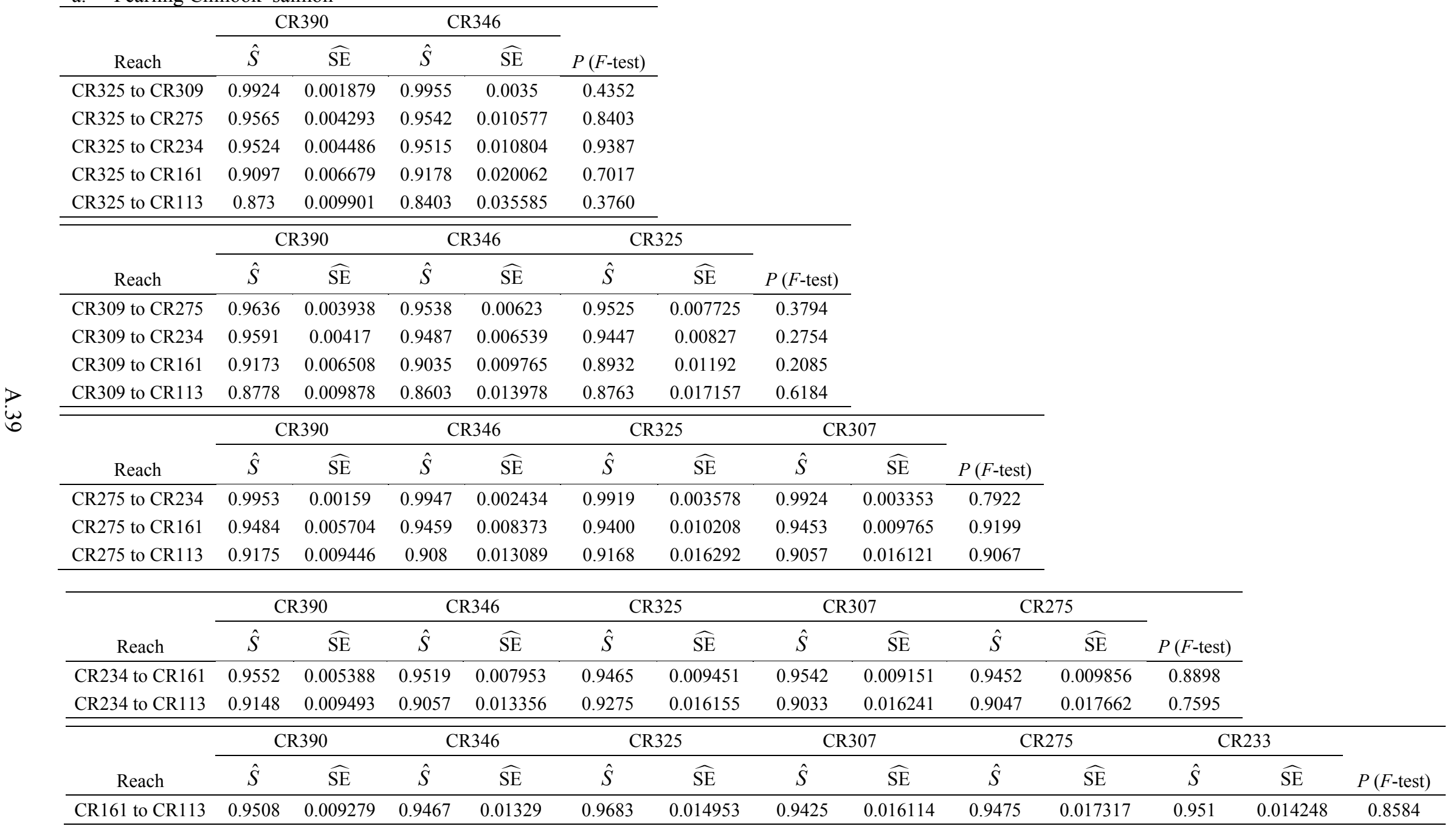


Table A.7. (contd)

b. Steelhead

\begin{tabular}{|c|c|c|c|c|c|c|c|c|c|c|c|c|c|}
\hline \multirow[b]{2}{*}{ Reach } & \multicolumn{2}{|c|}{ CR390 } & \multicolumn{3}{|c|}{ CR346 } & \multirow[b]{2}{*}{$P(F$-test $)$} & & & & & & & \\
\hline & $\hat{S}$ & $\widehat{\mathrm{SE}}$ & $\hat{S}$ & $\widehat{\mathrm{SE}}$ & & & & & & & & & \\
\hline CR325 to CR309 & 0.9932 & 0.001732 & 0.9847 & 0.0036 & & 0.0339 & & & & & & & \\
\hline CR325 to CR275 & 0.9732 & 0.003501 & 0.9623 & 0.005 & & 0.1045 & & & & & & & \\
\hline CR325 to CR234 & 0.9566 & 0.004246 & 0.9521 & 0.0063 & & 0.5548 & & & & & & & \\
\hline CR325 to CR161 & 0.9075 & 0.006436 & 0.8938 & 0.0096 & & 0.2366 & & & & & & & \\
\hline \multirow[t]{2}{*}{ CR325 to CR113 } & 0.8798 & 0.011103 & 0.8527 & 0.0157 & & 0.1593 & & & & & & & \\
\hline & \multicolumn{2}{|c|}{ CR390 } & \multicolumn{3}{|c|}{ CR346 } & \multicolumn{2}{|c|}{ CR325 } & & & & & & \\
\hline Reach & $\hat{S}$ & $\widehat{\mathrm{SE}}$ & $\hat{S}$ & $\widehat{\mathrm{SE}}$ & & $\hat{S}$ & $\widehat{\mathrm{SE}}$ & $P(F$-test $)$ & & & & & \\
\hline CR309 to CR275 & 0.9795 & 0.003114 & 0.9770 & 0.0045 & & 0.9663 & 0.006767 & 0.1449 & & & & & \\
\hline CR309 to CR234 & 0.9628 & 0.003942 & 0.9667 & 0.0053 & & 0.9476 & 0.007999 & 0.0587 & & & & & \\
\hline CR309 to CR161 & 0.9137 & 0.006254 & 0.9055 & 0.0091 & & 0.8998 & 0.011579 & 0.5660 & & & & & \\
\hline \multirow[t]{2}{*}{ CR309 to CR113 } & 0.8869 & 0.011095 & 0.8628 & 0.0156 & & 0.8932 & 0.021076 & 0.3864 & & & & & \\
\hline & \multicolumn{2}{|c|}{ CR390 } & \multicolumn{3}{|c|}{ CR346 } & \multicolumn{2}{|c|}{ CR325 } & \multicolumn{2}{|c|}{ CR307 } & & & & \\
\hline Reach & $\hat{S}$ & $\widehat{\mathrm{SE}}$ & $\hat{S}$ & $\widehat{\mathrm{SE}}$ & & $\hat{S}$ & $\widehat{\mathrm{SE}}$ & $\hat{S}$ & $\widehat{\mathrm{SE}}$ & $P(F$-test & & & \\
\hline CR275 to CR234 & 0.9832 & 0.002878 & 0.9895 & 0.0032 & & 0.9807 & 0.005444 & 0.9816 & 0.005216 & 0.4769 & & & \\
\hline CR275 to CR161 & 0.9346 & 0.005959 & 0.9251 & $0.008 \mathrm{~s}$ & & 0.9334 & 0.010451 & 0.9199 & 0.011227 & 0.6431 & & & \\
\hline \multirow[t]{2}{*}{ CR275 to CR113 } & 0.9049 & 0.010877 & 0.8887 & 0.015 & & 0.9408 & 0.020741 & 0.8824 & 0.019403 & 0.0699 & & & \\
\hline & \multicolumn{2}{|c|}{ CR390 } & \multicolumn{3}{|c|}{ CR346 } & \multicolumn{2}{|c|}{ CR325 } & \multicolumn{2}{|c|}{ CR307 } & \multicolumn{2}{|c|}{ CR275 } & & \\
\hline Reach & $\hat{S}$ & $\widehat{\mathrm{SE}}$ & $\hat{S}$ & $\widehat{\mathrm{SE}}$ & & $\hat{S}$ & $\widehat{\mathrm{SE}}$ & $\hat{S}$ & $\widehat{\mathrm{SE}}$ & $\hat{S}$ & $\widehat{\mathrm{SE}}$ & $P(F-1$ & -test) \\
\hline CR234 to CR161 & 0.9481 & 0.005237 & 0.9368 & 0.0079 & & 0.9496 & 0.00921 & 0.9402 & 0.009665 & 0.938 & 0.009601 & & 478 \\
\hline \multirow[t]{2}{*}{ CR234 to CR113 } & 0.9192 & 0.010907 & 0.8925 & 0.0154 & & 0.9437 & 0.020814 & 0.8886 & 0.019067 & 0.8859 & 0.018182 & & 788 \\
\hline & \multicolumn{2}{|c|}{ CR390 } & \multicolumn{2}{|c|}{ CR346 } & \multicolumn{2}{|r|}{ CR325 } & \multicolumn{2}{|c|}{ CR307 } & \multicolumn{2}{|c|}{ CR275 } & \multicolumn{2}{|c|}{ CR233 } & \\
\hline Reach & $\hat{S}$ & $\widehat{\mathrm{SE}}$ & $\hat{S}$ & $\widehat{\mathrm{SE}}$ & $\hat{S}$ & $\widehat{\mathrm{SE}}$ & $\hat{S}$ & $\widehat{\mathrm{SE}}$ & $\hat{S}$ & $\widehat{\mathrm{SE}}$ & $\hat{S}$ & $\widehat{\mathrm{SE}}$ & $P(F$-test $)$ \\
\hline CR161 to CR113 & 0.9651 & 0.01067 & 0.9459 & 0.014803 & 0.9828 & 0.020228 & 0.9385 & 0.018589 & 0.94 & 0.017674 & 0.9403 & 0.017119 & 0.3321 \\
\hline
\end{tabular}




\section{Appendix B}

Capture Histories Used in Estimating Dam Passage Survival 


\section{Appendix B}

\section{Capture Histories Used in Estimating Dam Passage Survival}

Table B.1. Capture histories at sites at rkm 325, 309, 275, 234, 161, 113, and 86 (Figure 2.1) for release group $V_{1}$ for yearling Chinook salmon used in estimating dam passage survival and BRZ-toBRZ survival. A " 1 " denotes detection, "0" denotes nondetection, and " 2 " denotes detection and censoring due to removal.

\begin{tabular}{|c|c|c|}
\hline \multirow[t]{2}{*}{ Capture History } & \multicolumn{2}{|l|}{$V_{1}$ (Season-Wide) } \\
\hline & Dam Passage Survival & BRZ-to-BRZ Survival \\
\hline $\begin{array}{llllllll}1 & 1 & 1 & 1 & 1 & 1 & 1\end{array}$ & 910 & 911 \\
\hline 01111111 & 4 & 4 \\
\hline 1011111 & 3 & 3 \\
\hline 1101111 & 30 & 30 \\
\hline 1001111 & 1 & 1 \\
\hline 1111011 & 115 & 116 \\
\hline 0111011 & 1 & 1 \\
\hline 1011011 & 2 & 2 \\
\hline 1101011 & 7 & 7 \\
\hline 0101011 & 1 & 1 \\
\hline 1111101 & 274 & 274 \\
\hline 0111101 & 1 & 1 \\
\hline 1101101 & 13 & 13 \\
\hline 0101101 & 1 & 1 \\
\hline 1111001 & 50 & 50 \\
\hline 0111001 & 1 & 1 \\
\hline 1101001 & 3 & 3 \\
\hline 0101001 & 1 & 1 \\
\hline 1111110 & 287 & 287 \\
\hline 0111110 & 7 & 7 \\
\hline 1011110 & 8 & 8 \\
\hline 1101110 & 44 & 44 \\
\hline 0101110 & 1 & 1 \\
\hline 1111010 & 64 & 64 \\
\hline 0111010 & 4 & 4 \\
\hline 1011010 & 1 & 1 \\
\hline 1101010 & 13 & 13 \\
\hline 0101010 & 1 & 1 \\
\hline 1111100 & 149 & 149 \\
\hline 0111100 & 5 & 5 \\
\hline 1011100 & 1 & 1 \\
\hline 1101100 & 36 & 35 \\
\hline 0101100 & 2 & 2 \\
\hline
\end{tabular}


Table B.1. (contd)

\begin{tabular}{|c|c|c|}
\hline \multirow[t]{2}{*}{ Capture History } & \multicolumn{2}{|l|}{$V_{1}($ Season-Wide $)$} \\
\hline & Dam Passage Survival & BRZ-to-BRZ Survival \\
\hline 111120000 & 58 & 58 \\
\hline 1111000 & 116 & 116 \\
\hline 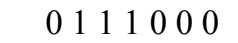 & 2 & 2 \\
\hline 1011000 & 3 & 3 \\
\hline 1101000 & 8 & 8 \\
\hline 0101000 & 2 & 2 \\
\hline 1001000 & 1 & 1 \\
\hline 1110000 & 10 & 10 \\
\hline 0110000 & 1 & 1 \\
\hline $\begin{array}{lllllll}1 & 1 & 0 & 0 & 0 & 0 & 0\end{array}$ & 84 & 84 \\
\hline 0100000 & 2 & 2 \\
\hline $\begin{array}{llllllll}1 & 0 & 0 & 0 & 0 & 0 & 0\end{array}$ & 19 & 19 \\
\hline 000000000 & 94 & 102 \\
\hline Total & 2,441 & 2,450 \\
\hline
\end{tabular}


Table B.2. Capture histories at sites at $\mathrm{rkm} 325,309,275,234,161,113$, and 86 (Figure 2.1) for release group $V_{1}$ for yearling Chinook salmon used in estimating dam passage survival and BRZ-toBRZ survival. A " 1 " denotes detection, " 0 " denotes nondetection, and " 2 " denotes detection and censoring due to removal.

\begin{tabular}{|c|c|c|c|c|}
\hline \multirow[t]{3}{*}{ Capture History } & \multicolumn{4}{|c|}{$V_{1}$ (Spill Treatments) } \\
\hline & \multicolumn{2}{|c|}{ Early Season } & \multirow[b]{2}{*}{$\begin{array}{c}\text { Capture History } \\
\text { (without rkm } 86 \text { ) }\end{array}$} & \multirow{2}{*}{$\begin{array}{c}\text { Late Season } \\
40 \% \text { Spill } \\
\text { Dam Passage }\end{array}$} \\
\hline & $\begin{array}{c}30 \% \text { Spill } \\
\text { Dam Passage }\end{array}$ & $\begin{array}{c}40 \% \text { Spill } \\
\text { Dam Passage }\end{array}$ & & \\
\hline 1111111111 & 383 & 379 & 111111 & 298 \\
\hline 1011111 & 1 & 0 & 0111111 & 11 \\
\hline 1101111 & 4 & 0 & 101111 & 10 \\
\hline 1111011 & 45 & 20 & 110111 & 66 \\
\hline 1111101 & 143 & 74 & 01001111 & 1 \\
\hline 1101101 & 1 & 0 & 100111 & 1 \\
\hline 1111001 & 28 & 5 & 111101 & 81 \\
\hline 1101001 & 1 & 0 & 01111101 & 5 \\
\hline 1111110 & 85 & 33 & 101101 & 3 \\
\hline 1101110 & 3 & 0 & 110101 & 18 \\
\hline 1111010 & 27 & 3 & $\begin{array}{llllll}0 & 1 & 0 & 1 & 0 & 1\end{array}$ & 2 \\
\hline 1101010 & 2 & 0 & 111110 & 153 \\
\hline 1111100 & 42 & 8 & 0111110 & 6 \\
\hline 1101100 & 2 & 0 & 101110 & 1 \\
\hline 1112000 & 34 & 19 & 110110 & 46 \\
\hline 1111000 & 40 & 25 & $\begin{array}{lllllll}0 & 1 & 0 & 1 & 1 & 0\end{array}$ & 3 \\
\hline 1110000 & 3 & 3 & 111200 & 3 \\
\hline 1100000 & 33 & 23 & 111100 & 66 \\
\hline 10000000 & 10 & 4 & $\begin{array}{llllllllll}0 & 1 & 1 & 1 & 0 & 0\end{array}$ & 3 \\
\hline 00000000 & 44 & 22 & 101100 & 3 \\
\hline \multirow[t]{10}{*}{ Total } & 931 & 618 & 110100 & 10 \\
\hline & & & 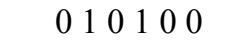 & 3 \\
\hline & & & 100100 & 1 \\
\hline & & & 111000 & 4 \\
\hline & & & 01110000 & 1 \\
\hline & & & 1100000 & 28 \\
\hline & & & 010000 & 2 \\
\hline & & & 100000 & 5 \\
\hline & & & 000000 & 26 \\
\hline & & & Total & 860 \\
\hline
\end{tabular}


Table B.3. Capture histories at sites at $\mathrm{rkm} 309,275,234,161,113$ and 86 (Figure 2.1) for release groups $R_{2}$, and $R_{3}$ for yearling Chinook salmon used in estimating dam passage survival. A " 1 " denotes detection, " 0 " denotes nondetection, and " 2 " denotes detection and censoring due to removal.

\begin{tabular}{|c|c|c|c|c|}
\hline \multirow[t]{2}{*}{ Capture History } & \multicolumn{2}{|c|}{$\begin{array}{l}\text { Dam Passage Survival (Season- } \\
\text { Wide) }\end{array}$} & \multicolumn{2}{|c|}{ Dam Passage Survival (30\% \& 40\% Spill) } \\
\hline & $R_{2}$ & $R_{3}$ & $R_{2}$ & $R_{3}$ \\
\hline 11111111 & 454 & 314 & 372 & 258 \\
\hline 0101111111 & 1 & 3 & 1 & 0 \\
\hline 101111 & 14 & 13 & 0 & 0 \\
\hline 111011 & 75 & 31 & 44 & 19 \\
\hline 0111011 & 0 & 1 & 0 & 0 \\
\hline 101011 & 4 & 3 & 0 & 0 \\
\hline 111101 & 140 & 83 & 107 & 55 \\
\hline 01011101 & 0 & 1 & 0 & 0 \\
\hline 101101 & 11 & 5 & 1 & 1 \\
\hline 111001 & 20 & 18 & 10 & 12 \\
\hline $\begin{array}{lllllll}0 & 1 & 1 & 0 & 0 & 1\end{array}$ & 0 & 1 & 0 & 1 \\
\hline 10101001 & 5 & 2 & 1 & 0 \\
\hline 111110 & 129 & 107 & 49 & 29 \\
\hline $\begin{array}{llllllllll}0 & 1 & 1 & 1 & 1 & 0\end{array}$ & 1 & 0 & 0 & 0 \\
\hline 101110 & 31 & 25 & 0 & 0 \\
\hline 111010 & 37 & 26 & 13 & 9 \\
\hline 01011010 & 0 & 0 & 0 & 0 \\
\hline 101010 & 10 & 6 & 1 & 0 \\
\hline 111100 & 74 & 47 & 21 & 14 \\
\hline 0111100 & 1 & 1 & 0 & 0 \\
\hline 101100 & 24 & 7 & 0 & 0 \\
\hline 112000 & 3 & 0 & 3 & 0 \\
\hline 111000 & 62 & 43 & 34 & 19 \\
\hline 0111000 & 1 & 0 & 0 & 0 \\
\hline 101000 & 10 & 6 & 1 & 2 \\
\hline 110000 & 6 & 6 & 5 & 6 \\
\hline 100000 & 55 & 38 & 37 & 19 \\
\hline 00000000 & 25 & 12 & 18 & 5 \\
\hline Total & 1,193 & 799 & 718 & 449 \\
\hline
\end{tabular}


Table B.4. Capture histories at sites at rkm 309, 275, 234, 161, and 113 (Figure 2.1) for release groups $R_{2}$, and $R_{3}$ for yearling Chinook salmon used in estimating dam passage survival during the late season. A " 1 " denotes detection, " 0 " denotes nondetection, and " 2 " denotes detection and censoring due to removal.

\begin{tabular}{|c|c|c|}
\hline \multirow[t]{2}{*}{ Capture History } & \multicolumn{2}{|c|}{ Dam Passage Survival (Late Season $40 \%$ Spill) } \\
\hline & $R_{2}$ & $R_{3}$ \\
\hline $\begin{array}{lllll}11 & 111\end{array}$ & 162 & 126 \\
\hline 0101111 & 1 & 3 \\
\hline 10111 & 45 & 38 \\
\hline 11101 & 55 & 22 \\
\hline 011101 & 0 & 1 \\
\hline 10101 & 13 & 9 \\
\hline 11110 & 86 & 58 \\
\hline $\begin{array}{lllllll}0 & 1 & 1 & 1 & 0\end{array}$ & 1 & 2 \\
\hline 10110 & 34 & 11 \\
\hline 11100 & 38 & 25 \\
\hline 01100 & 1 & 0 \\
\hline 10100 & 13 & 6 \\
\hline 110000 & 1 & 0 \\
\hline 100000 & 18 & 18 \\
\hline 00000 & 7 & 6 \\
\hline Total & $\overline{475}$ & 325 \\
\hline
\end{tabular}

Table B.5. Capture histories at sites at rkm 325, 309, 275, 234, 161, 113, and 86 (Figure 2.1) for release group $V_{1}$ for steelhead salmon used in estimating dam passage survival and BRZ-to-BRZ survival. A " 1 " denotes detection, " 0 " denotes nondetection, and " 2 " denotes detection and censoring due to removal.

\begin{tabular}{|c|c|c|}
\hline \multirow[t]{2}{*}{ Capture History } & \multicolumn{2}{|l|}{$V_{1}$ (Season-Wide) } \\
\hline & Dam Passage Survival & BRZ-to-BRZ Survival \\
\hline $\begin{array}{lllllllll} & 1 & 1 & 1 & 1 & 1 & 1\end{array}$ & 851 & 852 \\
\hline 0101111111 & 4 & 4 \\
\hline 1011111 & 1 & 1 \\
\hline 1101111 & 40 & 40 \\
\hline 1001111 & 1 & 1 \\
\hline 1111011 & 1 & 1 \\
\hline 0111011 & 53 & 53 \\
\hline 1011011 & 1 & 1 \\
\hline 1101011 & 7 & 7 \\
\hline 01010101011 & 273 & 274 \\
\hline 1111101 & 2 & 2 \\
\hline 011111101 & 1 & 1 \\
\hline 1101101 & 29 & 29 \\
\hline
\end{tabular}


Table B.5. (contd)

\begin{tabular}{|c|c|c|}
\hline \multirow[t]{2}{*}{ Capture History } & \multicolumn{2}{|l|}{$V_{1}$ (Season-Wide) } \\
\hline & Dam Passage Survival & BRZ-to-BRZ Survival \\
\hline $\begin{array}{lllllllllll}0 & 1 & 0 & 1 & 1 & 0 & 1\end{array}$ & 1 & 1 \\
\hline 1111001 & 17 & 17 \\
\hline 1101001 & 5 & 5 \\
\hline 0101001 & 1 & 1 \\
\hline 1111110 & 403 & 403 \\
\hline 0111110 & 12 & 12 \\
\hline 1011110 & 4 & 4 \\
\hline 1101110 & 98 & 98 \\
\hline 010101110 & 3 & 3 \\
\hline 1111010 & 59 & 59 \\
\hline 1011010 & 1 & 1 \\
\hline 1101010 & 11 & 11 \\
\hline 1111100 & 187 & 188 \\
\hline 01111100 & 5 & 5 \\
\hline 1011100 & 5 & 5 \\
\hline 1101100 & 46 & 46 \\
\hline 010101100 & 3 & 3 \\
\hline 1112000 & 33 & 33 \\
\hline 1111000 & 113 & 113 \\
\hline 01111000 & 1 & 1 \\
\hline 1011000 & 3 & 3 \\
\hline 1101000 & 21 & 21 \\
\hline 0101000 & 3 & 3 \\
\hline 1001000 & 1 & 1 \\
\hline 1110000 & 36 & 36 \\
\hline 1100000 & 53 & 53 \\
\hline 01000000 & 1 & 1 \\
\hline 1000000 & 17 & 17 \\
\hline $\begin{array}{lllllllll}0 & 0 & 0 & 0 & 0 & 0\end{array}$ & 62 & 79 \\
\hline Total & 2,469 & 2,489 \\
\hline
\end{tabular}


Table B.6. Capture histories at sites at $\mathrm{rkm} 325,309,275,234,161,113$, and 86 (Figure 2.1) for release group $V_{1}$ for steelhead salmon used in estimating dam passage survival and BRZ-to-BRZ survival. A " 1 " denotes detection, " 0 " denotes nondetection, and " 2 " denotes detection and censoring due to removal.

\begin{tabular}{|c|c|c|c|}
\hline \multirow{3}{*}{ Capture History } & \multicolumn{2}{|c|}{$V_{1}$ (Spill Treatments) } & \multirow{3}{*}{$\begin{array}{c}\text { Late Season } \\
40 \% \text { Spill } \\
\text { Dam Passage } \\
\end{array}$} \\
\hline & \multicolumn{2}{|c|}{ Early Season } & \\
\hline & $\begin{array}{c}30 \% \text { Spill } \\
\text { Dam Passage }\end{array}$ & $\begin{array}{c}40 \% \text { Spill } \\
\text { Dam Passage }\end{array}$ & \\
\hline $\begin{array}{llllllll} & 1 & 1 & 1 & 1 & 1\end{array}$ & 401 & 343 & 106 \\
\hline 01111111 & 1 & 0 & 3 \\
\hline 1011111 & 0 & 0 & 1 \\
\hline 1101111 & 1 & 1 & 38 \\
\hline 0101011111 & 0 & 0 & 1 \\
\hline 1001111 & 0 & 0 & 1 \\
\hline 1111011 & 24 & 3 & 26 \\
\hline $\begin{array}{lllllllllll} & 0 & 1 & 0 & 1 & 1\end{array}$ & 0 & 0 & 1 \\
\hline 110010011 & 0 & 0 & 7 \\
\hline 111111101 & 130 & 83 & 59 \\
\hline 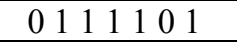 & 1 & 0 & 1 \\
\hline 100111101 & 2 & 0 & 1 \\
\hline 101011101 & 0 & 0 & 27 \\
\hline 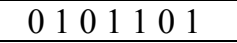 & 0 & 0 & 1 \\
\hline 1111001 & 9 & 0 & 6 \\
\hline 111110001 & 1 & 1 & \\
\hline 110010001 & 0 & 0 & 5 \\
\hline 1111110 & 144 & 57 & 198 \\
\hline 00111111110 & 1 & 0 & 11 \\
\hline 100111110 & 0 & 0 & 4 \\
\hline 1101110 & 8 & 0 & 90 \\
\hline 0 & 0 & 0 & 3 \\
\hline 1111010 & 15 & 3 & 40 \\
\hline 1011010 & 0 & 0 & 1 \\
\hline 1101010 & 1 & 0 & 10 \\
\hline 1111100 & 54 & 14 & 118 \\
\hline 011111100 & 1 & 0 & 4 \\
\hline 1011100 & 0 & 1 & 4 \\
\hline 1101100 & 1 & 0 & 45 \\
\hline $\begin{array}{lllllllllll}0 & 0 & 1 & 0 & 0\end{array}$ & 0 & 0 & 3 \\
\hline 1112000 & 15 & 16 & 2 \\
\hline 1111000 & 32 & 25 & 55 \\
\hline 011110000 & 0 & 0 & 1 \\
\hline 1011000 & 0 & 1 & 2 \\
\hline 1101000 & 3 & 0 & 18 \\
\hline 0101010000 & 0 & 0 & 3 \\
\hline
\end{tabular}


Table B.6. (contd)

\begin{tabular}{|c|c|c|c|}
\hline \multirow[t]{3}{*}{ Capture History } & \multicolumn{2}{|c|}{$V_{1}$ (Spill Treatments) } & \\
\hline & \multicolumn{2}{|c|}{ Early Season } & Late Season \\
\hline & $\begin{array}{c}30 \% \text { Spill } \\
\text { Dam Passage }\end{array}$ & $\begin{array}{c}40 \% \text { Spill } \\
\text { Dam Passage }\end{array}$ & $\begin{array}{c}40 \% \text { Spill } \\
\text { Dam Passage }\end{array}$ \\
\hline 1001000 & 0 & 0 & 1 \\
\hline 1110000 & 17 & 14 & 5 \\
\hline 1100000 & 23 & 16 & 13 \\
\hline 01000000 & 0 & 0 & 1 \\
\hline 1000000 & 4 & 4 & 9 \\
\hline 000000000 & 30 & 16 & 14 \\
\hline Total & 919 & 598 & 939 \\
\hline
\end{tabular}

Table B.7. Capture histories at sites at rkm 309, 275, 234, 161, 113 and 86 (Figure 2.1) for release groups $R_{2}$, and $R_{3}$ for steelhead salmon used in estimating dam passage survival. A " 1 " denotes detection, " 0 " denotes nondetection, and " 2 " denotes detection and censoring due to removal.

\begin{tabular}{|c|c|c|c|c|}
\hline \multirow[t]{2}{*}{ Capture History } & \multicolumn{2}{|c|}{ Dam Passage Survival (Season-Wide) } & \multicolumn{2}{|c|}{ Dam Passage Survival (30\% \& 40\% Spill) } \\
\hline & $R_{2}$ & $R_{3}$ & $R_{2}$ & $R_{3}$ \\
\hline $\begin{array}{llllll}1 & 1 & 1 & 1 & 1\end{array}$ & 431 & 258 & 370 & 226 \\
\hline 010111111 & 1 & 0 & 0 & 0 \\
\hline 101111 & 25 & 15 & 0 & 0 \\
\hline 111011 & 21 & 15 & 15 & 7 \\
\hline 101011 & 3 & 3 & 0 & 0 \\
\hline 111101 & 134 & 92 & 103 & 67 \\
\hline $\begin{array}{lllllll}0 & 1 & 1 & 1 & 0 & 1\end{array}$ & 0 & 1 & 0 & 0 \\
\hline 101101 & 16 & 5 & 0 & 0 \\
\hline 111001 & 13 & 7 & 9 & 3 \\
\hline 101001 & 1 & 4 & 0 & 0 \\
\hline 111110 & 194 & 159 & 92 & 65 \\
\hline 101110 & 46 & 30 & 1 & 0 \\
\hline 111010 & 25 & 19 & 6 & 5 \\
\hline 101010 & 6 & 14 & 0 & 0 \\
\hline 111100 & 100 & 56 & 35 & 19 \\
\hline 101100 & 32 & 23 & 0 & 0 \\
\hline 112000 & 1 & 0 & 0 & 0 \\
\hline 111000 & 73 & 36 & 42 & 20 \\
\hline 101000 & 10 & 11 & 0 & 0 \\
\hline 1100000 & 11 & 13 & 10 & 11 \\
\hline 1000000 & 29 & 29 & 16 & 21 \\
\hline 0000000 & 24 & 7 & 16 & 3 \\
\hline Total & 1,196 & 797 & 715 & 447 \\
\hline
\end{tabular}


Table B.8. Capture histories at sites at $\mathrm{rkm} 309,275,234,161,113$, and 86 (Figure 2.1) for release groups $R_{2}$, and $R_{3}$ for steelhead salmon used in estimating dam passage survival during the late season. A " 1 " denotes detection, " 0 " denotes nondetection, and " 2 " denotes detection and censoring due to removal.

\begin{tabular}{|c|c|c|}
\hline \multirow[t]{2}{*}{ Capture History } & \multicolumn{2}{|c|}{ Dam Passage Survival (Late Season $40 \%$ Spill) } \\
\hline & $R_{2}$ & $R_{3}$ \\
\hline $\begin{array}{llllll}1 & 1 & 1 & 1 & 1\end{array}$ & 61 & 25 \\
\hline 011111 & 1 & 0 \\
\hline 101111 & 25 & 15 \\
\hline 111011 & 6 & 7 \\
\hline 101011 & 3 & 3 \\
\hline 111101 & 31 & 21 \\
\hline 01111101 & 0 & 1 \\
\hline 101101 & 16 & 5 \\
\hline 111001 & 4 & 3 \\
\hline 101001 & 1 & 4 \\
\hline 111110 & 102 & 88 \\
\hline 101110 & 45 & 30 \\
\hline 111010 & 19 & 13 \\
\hline 101010 & 6 & 14 \\
\hline 111100 & 65 & 36 \\
\hline 101100 & 32 & 22 \\
\hline 112000 & 1 & 0 \\
\hline 111000 & 31 & 16 \\
\hline 101000 & 10 & 11 \\
\hline 1100000 & 1 & 1 \\
\hline 10000000 & 13 & 6 \\
\hline $\begin{array}{lllllll}0 & 0 & 0 & 0 & 0 & 0\end{array}$ & 8 & 4 \\
\hline Total & 481 & 325 \\
\hline
\end{tabular}




\section{Distribution}

No. of

Copies

OFFSITE

Brad Eppard

USACE Portland District

P.O. Box 2946

Portland, OR 97204

Mike Langeslay

USACE Portland District

P.O. Box 2946

Portland, OR 97204

John Skalski

University of Washington

$13254^{\text {th }}$ Avenue

Seattle, WA 98101
No. of

Copies

\section{ONSITE}

\section{Pacific Northwest National Laboratory}

$\begin{array}{lr}\text { TJ Carlson } & \text { BPO } \\ \text { GE Johnson } & \text { BPO } \\ \text { GR Ploskey } & \text { NBON } \\ \text { S Schlahta } & \text { K6-83 } \\ \text { MA Weiland } & \text { NBON }\end{array}$




\section{ingi,}

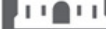

US Army Corps

of Engineers

Prepared for the U.S. Army Corps of Engineers, Portland District, under a Government Order with the U.S. Department of Energy

Contract DE-AC05-76RL01830

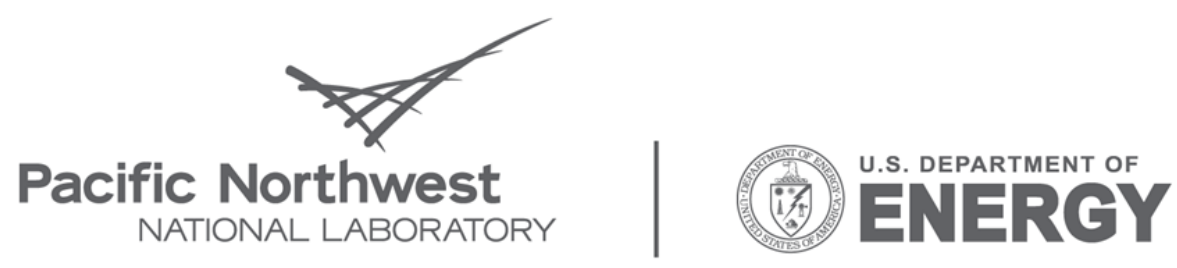

Proudly Operated by Battelle Since 1965

902 Battelle Boulevard

P.O. Box 999

Richland, WA 99352

1-888-375-PNNL (7665)

www.pnl.gov 